University of Louisville

ThinkIR: The University of Louisville's Institutional Repository

Electronic Theses and Dissertations

$12-2010$

\title{
Simulation analysis of resident and attending physician teaching methods at Kosair Children's Hospital.
}

Scott R. Hoover

University of Louisville

Follow this and additional works at: https://ir.library.louisville.edu/etd

\section{Recommended Citation}

Hoover, Scott R., "Simulation analysis of resident and attending physician teaching methods at Kosair Children's Hospital." (2010). Electronic Theses and Dissertations. Paper 631.

https://doi.org/10.18297/etd/631

This Master's Thesis is brought to you for free and open access by ThinkIR: The University of Louisville's Institutional Repository. It has been accepted for inclusion in Electronic Theses and Dissertations by an authorized administrator of ThinkIR: The University of Louisville's Institutional Repository. This title appears here courtesy of the author, who has retained all other copyrights. For more information, please contact thinkir@louisville.edu. 


\title{
SIMULATION ANALYSIS OF RESIDENT AND ATTENDING PHYSICIAN TEACHING METHODS AT KOSAIR CHILDREN'S HOSPITAL
}

\author{
By
}

Scott Hoover

B.S. Mathematics, University of Louisville, 2009

\author{
A Thesis \\ Submitted to the Faculty of the \\ University of Louisville \\ J.B. Speed School of Engineering \\ in Partial Fulfillment of the Requirements \\ for the Professional Degree
}

MASTER OF SCIENCE IN INDUSTRIAL ENGINEERING

Department of Industrial Engineering

December 2010 



\section{SIMULATION ANALYSIS OF RESIDENT AND ATTENDING PHYSICIAN TEACHING METHODS AT KOSAIR CHILDREN'S HOSPITAL}

Submitted by:

Scott Hoover
A Thesis Approved On
$12 / 3 / 10$
(Date)

by the Following Reading and Examination Committee:

Dr. Gail Depuy, Thesis Director

Dr. Grady T. Holman

Dr. Eric Rouchka 


\section{ACKNOWLEDGEMENT}

I would first like to thank Dr. Eric Rouchka for taking the time on such short notice to be on my committee. I would also like to thank Dr. Talley Holman for serving on my committee and for his insights and encouragement throughout my Master's Degree. I would also like to give a special thanks to my thesis director, Dr. Gail Depuy, for her guidance and for encouraging me to pursue a career as an Industrial Engineer.

I would also like to thank Kosair Children's Hospital for allowing me to conduct this simulation in their emergency department. In particular, I would like to thank Carla Sanders and Liz Younger for taking their time to help me understand the process of the emergency department.

I would also like to thank my parents, Todd and Karen Hoover, who have always trusted and supported every decision I have made. Their love and guidance have made me who I am today.

Lastly, I would like to thank my wife, Sarah. If not for her love, patience, and encouragement, I would have struggled through these past few years. Her constant support has helped me to remain confident in myself. 


\title{
ABSTRACT \\ SIMULATION ANALYSIS OF RESIDENT AND ATTENDING PHYSICIAN TEACHING METHODS AT KOSAIR CHILDREN'S HOSPITAL
}

\author{
Scott Hoover
}

December 3, 2010

The Kosair Children's Hospital, located in Louisville, Kentucky, is the only children's hospital in the state. Recently, the hospital's emergency department has developed concerns with patient satisfaction. Patients have experienced excessive amounts of time to get through the emergency department resulting in low satisfaction. Hence, this research assesses the patient's time in the emergency department through the use of a computer simulation. Specifically, a study on the teaching methods for the resident physicians was examined to determine if there were different approaches that could be implemented to improve a patient's time in the emergency department.

Findings showed that the teaching method of having an attending physician with the resident physician whenever they visit a patient was the best teaching method. This teaching method only showed significant improvement if the number of attending physicians was adjusted from two to three starting at 3:00 PM until 11:00 PM. These changes resulted in a $28 \%$ reduction of total time in the system for patients. These results provide a starting point for Kosair to make improvements to their emergency department; however, there are areas that warrant further research. 


\section{TABLE OF CONTENTS}

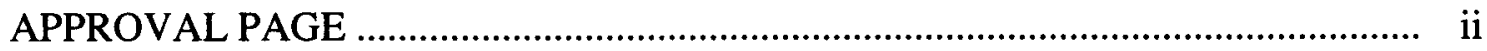

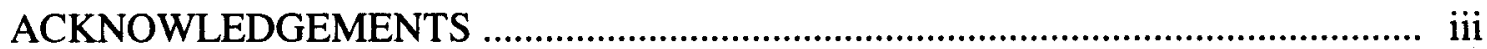

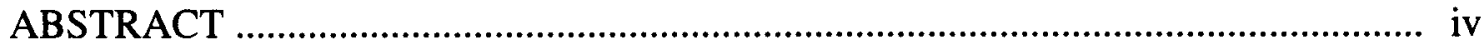

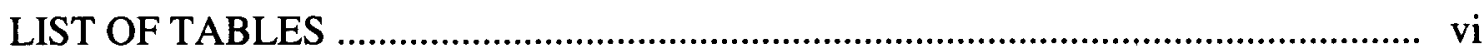

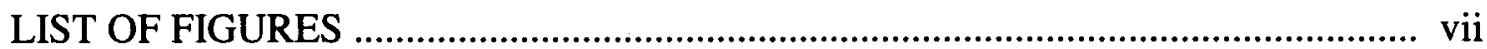

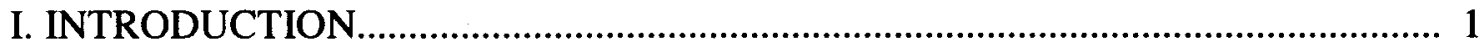

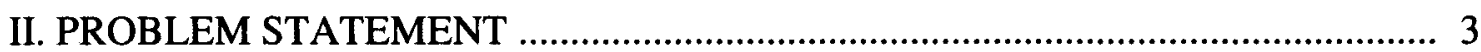

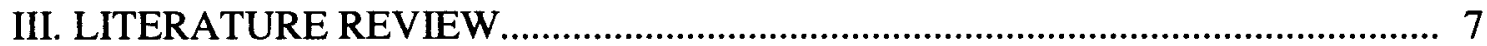

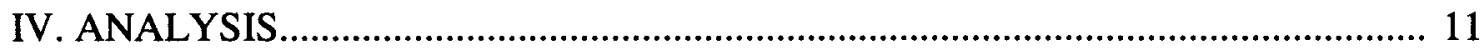

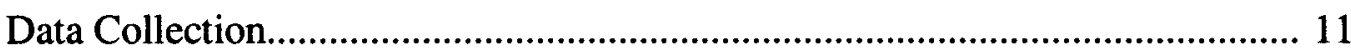

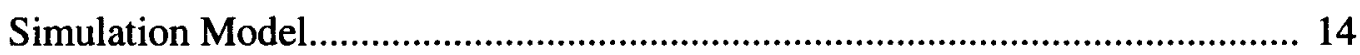

Model Verification and Validation............................................................ 22

Testing Alternative Methods...................................................................... 23

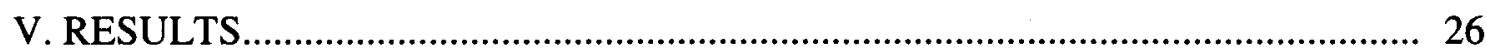

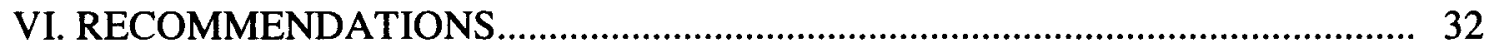

VII. CONCLUSIONS AND FUTURE RESEARCH........................................... 34

REFERENCES

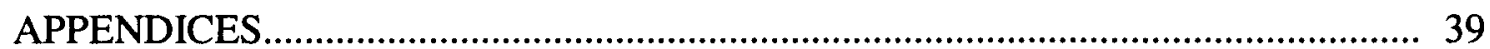

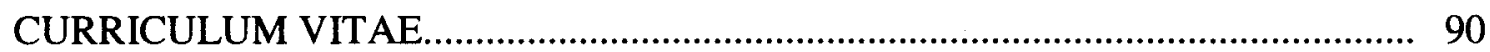




\section{LIST OF TABLES}

TABLE I - Sample of Collected Data.................................................................. 12

TABLE II - Emergency Department Process/Delay Probability Distributions.............. 13

TABLE III - Triangular Distribution Values for Processes/Delays................................ 14

TABLE IV - Next Procedure Probabilities............................................................... 14

TABLE V - Patient Arrival Rates.................................................................. 16

TABLE VI - Percent of Next Staff Members.......................................................... 18

TABLE VII - Staff Levels.................................................................................... 20

TABLE VIII - Results of Current and Two Different Teaching Method...................... 27

TABLE IX - Adjustments to Attending Staff Schedule................................................ 29

TABLE X - Results of Teaching Methods with New Staff Level................................. 30 


\section{LIST OF FIGURES}

FIGURE I - Map of Kosair Emergency Department.......................................... 3

FIGURE II - Flow chart of Emergency Department Process..................................... 5

FIGURE III - Patients Arrive, Register, and were Triaged....................................... 16

FIGURE IV - Patient Seizes Room, Assigned Attribute/Variable, and Nurse Visits.... 18

FIGURE V - Patient was Visited by a Staff Member.............................................. 19

FIGURE VI - Decision on Where the Patient Goes Next........................................... 21

FIGURE VII - X-Ray, Cat-Scan, and Procedure Room Process.................................. 22

FIGURE VIII - Patient Reroutes Through the System or has Last Visit....................... 23

FIGURE IX - Exam Room was Released and Patient Leaves.................................... 23

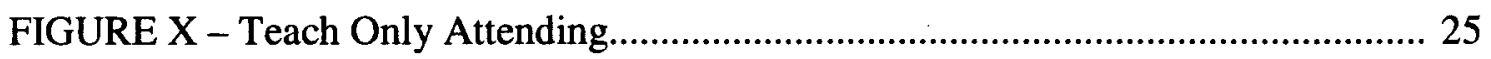

FIGURE XI - Resident with Attending............................................................... 26

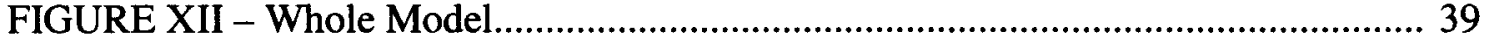




\section{INTRODUCTION}

According to the U.S. Department of Health and Human Services Centers for Disease Control and Prevention (2009), 10 million children (14\% of all children) living in the United States had an emergency department (ED) visit in the previous twelve months, and 5.2 million children ( $7 \%$ of all children) had two or more visits in 2008 . It can be expected from these high numbers of visits to emergency departments that patient wait times have increased. (Thompson \& Yarnold, 1995)

The Kosair Children's Hospital, located in Louisville, Kentucky is the only children's hospital in the state and serves nearly 59,000 patients annually. Recently, Kosair has experienced decreased patient satisfaction in their emergency department, which is a quarterly metric that administration evaluates. Now concerns exist that this decrease has become a trend because the Kosair ED was below the set goal for all four quarters in 2009 (Gentry, 2009).

It has been well documented that a patient's wait time in the emergency department is a key factor in the patient's satisfaction of their visit (Boudreaux, Ary, Mandry, \& McCabe, 2000; Anderson, Camacho, \& Balkrishnan, 2007). In 2009, the average time spent in the emergency department at Kosair Hospital was longer than 4.5 hours compared to a national average of 3.3 hours (Nawar, Niska, \& Xu, 2007). This lengthy amount of time spent in the department has led to the low satisfaction scores obtained by the hospital. Thus, the purpose of this study was to improve the patient 
satisfaction by determining methods and solutions to lower a patient's total time, by means of reducing a patient's wait time, in the emergency department of Kosair Children's Hospital.

The remainder of this study is organized as follows: Chapter II discusses the problems of the emergency department in depth. Chapter III contains a discussion of the literature pertaining to this particular topic. Chapter IV provides insight on the methodology of this study. Chapter V reports the results of the performed analysis. Chapter VI provides recommendations for the hospital to implement. Finally, Chapter VII provides an overview of the important findings and topics of future research areas. 


\section{PROBLEM STATEMENT}

The emergency department at Kosair Children's Hospital is a teaching department for medical students at the University of Louisville. The emergency department has a total of 30 examination rooms, including the trauma rooms, which were split up between three hallways; hallways A, B, and C. A map of the sections of the emergency department that were analyzed is shown in Figure I. There was also an ED section designated as "Kids Express," which was only open during certain times of the day and is used for less severe patients. When Kids Express was not open, all patients use the main emergency department. NOTE: This study focused only on the main emergency department.

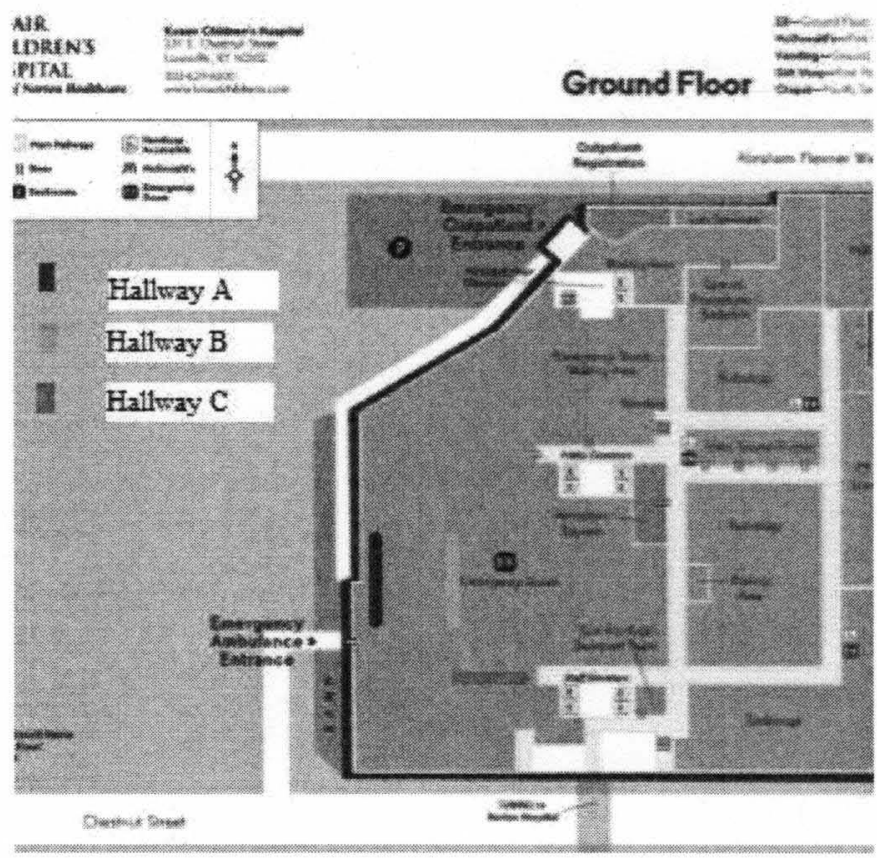

Figure I - Map of Kosair Emergency Department 
For admission, there were multiple ways a patient could enter the ED. Most patients enter the emergency department through the front entrance going through the typical process of registering and being triaged. Severe patients that enter through the waiting room skip the initial registration and were taken straight to triage. Some patients enter the emergency department by ambulance. This study focused strictly on the typical patient who enters via the waiting room.

Ideally, when a patient arrives to the emergency department they should go immediately to the registration desk, where they were put in cue for the triage nurse to determine their priority. The delay while in cue was normally done in the "waiting room." When a patient was triaged, a nurse takes the patient to a triage room where vitals of the patient were taken along with an initial assessment. If possible, the patient or family member explains the patient's symptoms and history that lead up to the arrival at the ED. From this information, the nurse assigns an acuity level (least severe to severe: green, blue, yellow, orange, red) to the patient. Once the patient was triaged they return to the waiting room. After their wait, they were taken back to the examination room. Once in the examination room, the patient was visited by a nurse followed by a possible visit from one to five staff members: the nurse again, a patient care advisor (PCA), a technician, a resident doctor, or an attending doctor. After this initial visit, the patient has the possibility of going to have an X-ray, cat-scan, procedure room, or remaining in their exam room. After, depending on the subjective and objective findings, the attending physician will either make an assessment and subsequent plan or the process may start again do to findings that were not conclusive. Hence, the patient could either be released from the emergency department to go home or admitted for observation and/or further 
test. If the patient was released, a final visit was performed by the nurse to provide the patient with their discharge instructions. Figure II provides a flow chart of the Kosair emergency department.

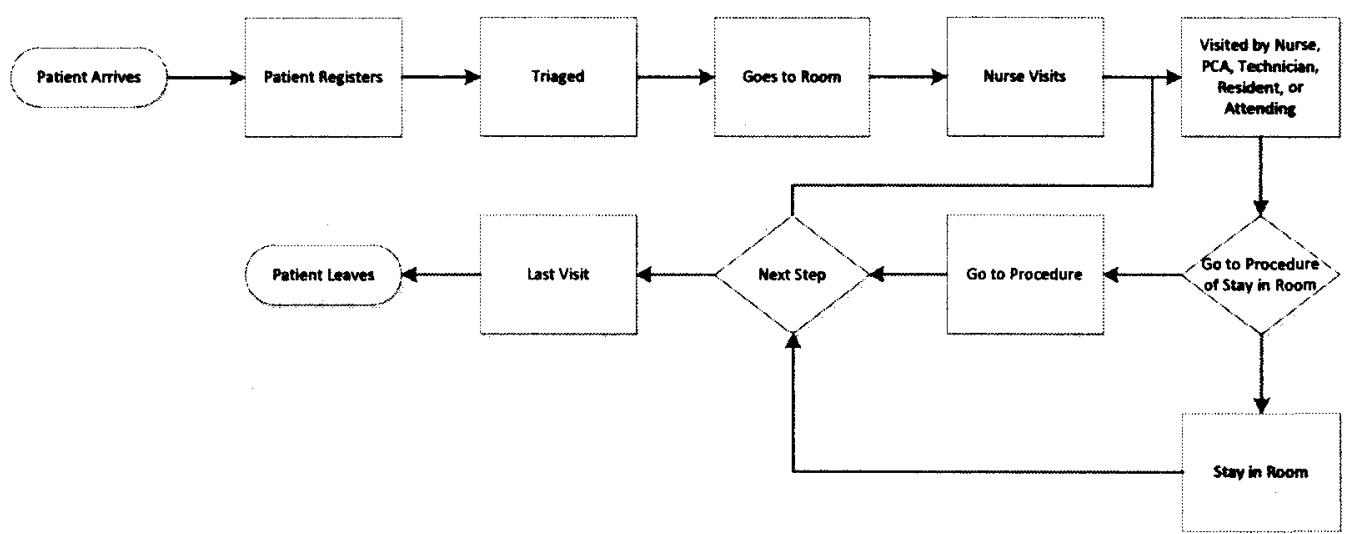

Figure II - Flow Chart of Emergency Department Process

Since the emergency department is a teaching facility, it requires the resident physicians to be supervised by attending physicians. This constant supervision adds extra time in to the process for the patient in the form of additional repeated assessments, increased cue times (delays), etc. For example, any visit to a patient a resident makes, they must then report back to the attending for consultation before the next medical step could be taken. This requirement of constantly reporting back to the attending physicians requires the patient to sit in the ED for an increased amount of time.

To combat this problem of increased wait time for patients, Kosair has asked that a study be conducted to investigate different teaching methods of the resident physicians, in hopes of reducing the length of stay for patients. Therefore, a computer simulation model was proposed and created to simulate the operation of the Kosair Hospital emergency department. The ultimate goal was that the simulation would be used to determine if new, more efficient teaching methods could be developed that would reduce the amount of time patient spend in the emergency department. 
Simulation has become an effective tool in many different areas other than healthcare. Many manufacturing companies use forms of computer simulation to model production lines to determine how to improve upon or implement a new line (Dengiz, 2009). The military has a variety of uses for computer simulation, including measuring the accuracy of new missiles or how to transport supplies (Law, 2007). Additionally, simulations have proven to be very useful in determining the best methods for call centers (Atlason, Epelman, \& Henderson, 2004).

The versatility of simulation shows why it is a viable tool to determine how different teaching methods will affect the length of stay of patients. A key aspect of simulation is that it can be done without interrupting the current system. This is very important because these changes can be studied without creating more problems in the emergency room, which could lead to even longer wait times or more severe consequences. 


\section{LITERATURE REVIEW}

The primary objective of this study is to reduce the patient wait time in the Kosair Children's Hospital's emergency department. The emergency department at Kosair is a medical teaching department that train resident doctors. Therefore, each patient a resident doctor diagnoses must also be evaluated by the attending physician to validate the resident's findings. This was one area of primary concern as a cause for the longer than average wait times for patients in the emergency department. The following is a review of the literature, which will provide insights for possible methods to improve this area. Two areas will be the primary focus for the literature:

1. Simulation methods for personnel scheduling in an emergency department.

2. Alternative methods for training resident physicians.

Recently, there have been numerous issues with increased patient wait time in emergency departments around the world. Many emergency departments have turned to research teams to determine a solution to expedite patients through the emergency department. One of the main tools these researchers use is simulation. Jun, Jacobson, and Swisher (1999) defined simulation in health care as "an operational research technique that allows the end user (namely, hospital administrators or clinic managers) to assess the efficiency of existing health care delivery systems, to ask 'what if?' questions, and to design new systems." The most important aspect of this definition is that simulation allows the user to ask and answer the 'what if?' questions. Researchers were able to test and see what happens when different aspects of the emergency department 
were changed. For example, Samaha, Armel, and Starks (2003) used simulation to determine different methods to decrease the length of stay of patients in a hospital in New Jersey. In particular, Samaha, et al. (2003) wanted to determine if increasing the department from 10,000 square feet to 25,000 square feet, implementing bedside registration for all patients, or creating a fast-track center would decrease the length of stay. They were able to determine that the fast-track center was the best method to decrease the patient length of stay.

As stated earlier, one of the primary focuses of this study was the scheduling of personnel. There have been many studies in this specific area. For instance, Rossetti, Trzcinski, and Syverud (1999) created four alternative physician schedules in order to compare and determine if improvements could be made. Their best physician schedule that was created decreased the wait time by 13 minutes. However, it did cause the utilization of the physicians to be lowered, as well. Evans, Gor, and Unger (1996) provide another use of simulation in determining optimal staffing schedules. In this study, the schedules of the nurses and technicians were adjusted so different numbers of each were on hand at different times of the day. Five different staffing schedules were created and it was determined that one of the proposed schedules was better than what was being implemented at the time. Draeger (1992) also used simulation to evaluate possible schedules for nurses in an emergency department in Cincinnati, Ohio.

Other researchers have also used simulation along with other engineering techniques to determine improved staffing schedules. Centeno, Giachetti, Linn, and Ismail (2003) used integer linear programming with simulation to develop a tool for scheduling staff. The purpose was to create appropriate nurse schedules to minimize the 
cost. With this tool, Centeno, et al. (2003) determined that the hospital could save almost $\$ 440,000$ with the proposed changes. Another engineering tool used by Yeh and Lin (2007) to determine appropriate staff schedules was the creation of a genetic algorithm. The genetic algorithm was developed to determine the near-optimal schedule for the nurses and it was determined that the average wait time for patients with the plan was reduced by $43 \%$.

The second part of this literature review focuses on alternative methods for training resident physicians in emergency departments. To date, there have been very few articles written on methods for training resident physicians. One manuscript, written by Aldeen and Gisondi (2006), focused on bedside teaching within emergency departments. A strategy found for effective bedside teaching was the "teach-only attending." Aldeen and Gisondi (2006) describe this process as, "interns (residents) in the emergency department were observed by attending physicians and given immediate feedback regarding their patient assessments." This "teach only" method could be implemented in Kosair by having one additional attending devoted to visiting and diagnosing patients with the residents, while the remaining attending physicians deal strictly with patient care and not be involved with teaching residents.

Chisholm, Whenmouth, Daly, Cordell, Giles, and Brizendine (2004) list different ways that attending and resident physicians interact with patients in an emergency department. They provided different methods for teaching resident physicians which could be simulated. In particular, two methods were tested in this study: 
1. Attending physician and resident simultaneously interact with a patient (this is different than the method Aldeen and Gisondi described in that all attending and resident physicians will interact with a patient).

2. Resident presents patient information to the attending physician (current operation in the Kosair emergency department).

Further, the primary goal of this study was to consider both areas by simulating how the different methods of teaching resident physicians and how adjusting the physician schedules affect the patient wait time through the overall emergency department. The desired outcome of this goal was to recommend a method for teaching residents that would minimize patient time in the emergency department of Kosair Children's Hospital. 


\section{ANALYSIS}

This chapter first focuses on the methods of collecting data, then addresses the simulation model, refining the simulation model, verifying and validating the simulation model, and testing the various teaching methods.

\section{Data Collection}

A meeting was set up with the management of Kosair Children's Hospital Emergency Department. In this initial meeting, management pointed out that since Kosair is a teaching hospital, a significant amount of the patient's time was spent waiting

for the attending physician to check over what the resident physician has done. A tour of the emergency department was given to provide a better understanding of how the emergency department operates.

Initial observations were performed by this researcher in April and May of 2010. These initial observations were completed strictly to gain a basic understanding of the processes in the emergency department and to collect timings of patients as they progress through the system. The first observations were performed by following a single patient as he/she travels through the emergency department. The patient was unaware of these observations. In these initial observations, six patients were observed. For each patient, basic information was recorded for simulation purposes, including items such as event, time of day related to each event, etc. Table I provides an example of some of the data collected in these initial observations. 
Table I

Sample of Collected Data

\begin{tabular}{|c|c|c|c|}
\hline Event & Time of Day & Event & Time of Day \\
\hline Patient Registers & $3: 11$ & Patient Goes to X-Ray & $4: 46$ \\
\hline Goes to Triage & $3: 15$ & Returns from X-Ray & $5: 01$ \\
\hline Exits Triage & $3: 23$ & Nurse Enters Room & $5: 17$ \\
\hline Goes to Room & $3: 37$ & Nurse Exits Room & $5: 22$ \\
\hline Nurse Enters Room & $3: 38$ & Attending Enters Room & $5: 37$ \\
\hline Nurse Exits Room & $3: 44$ & Attending Exits Room & $5: 39$ \\
\hline Resident Enters Room & $3: 45$ & Technician Enters & $6: 00$ \\
\hline Resident Exits Room & $4: 05$ & Technician Exits & $6: 01$ \\
\hline Attending Enters Room & $4: 16$ & Technician Enters & $6: 05$ \\
\hline Attending Exits Room & $4: 22$ & Nurse Enters Room & $6: 08$ \\
\hline Nurse Enters Room & $4: 31$ & Nurse Exits Room & $6: 10$ \\
\hline Nurse Exits Room & $4: 32$ & Technician Exits & $6: 22$ \\
\hline Nurse Enters Room & $4: 33$ & Patient Leaves & $6: 23$ \\
\hline Nurse Exits Room & $4: 34$ & & \\
\hline
\end{tabular}

In addition to the initial six patient observations, four weeks' of data spanning from April 18, 2010 to May 14, 2010 was provided by Kosair. The four weeks' of data provided 3,000 usable patient data points for each of the processes. Some of the patient data was excluded because the timings were blank. The provided data included, for each patient, total times from arrival to triage, triage to room assignment, room assignment to visit from physician, visit from physician to disposition, and disposition to discharge. In particular, two components of this provided data were used in this study:

1. Amount of time from arrival to patient triage

2. Amount of time from triage until patient enters exam room

The other times provided by Kosair were not useful for the simulation because the times represented a combination of several different tasks that needed to be modeled individually in the simulation. For these particular items/variables, times were collected 
via direct observation in accordance with evidence-based research practices. For this, two observes were utilized who were working on similar studies (Gentry, 2009). Once the data sets were collected, probability distributions were fitted using the Input Analyzer feature of the simulation software Arena@. Table II shows the probability distributions that were fitted using the Input Analyzer for each emergency department process or delay.

Table II

Emergency Department Process/Delay Probability Distributions

\begin{tabular}{|l|l|c|}
\hline \multicolumn{1}{|c|}{$\begin{array}{c}\text { Emergency Department } \\
\text { Process/Delay }\end{array}$} & \multicolumn{1}{|c|}{ Distribution } & $\begin{array}{c}\text { Square } \\
\text { Error }\end{array}$ \\
\hline Nurse Visit Process & $0.5+$ EXPO $(2.04)$ & 0.011 \\
\hline Resident/Attending Visit Process & $0.5+23 *$ BETA $(0.605,1.28)$ & 0.014 \\
\hline PCA Visit Process & $0.5+9 *$ BETA $(0.818,1.33)$ & 0.095 \\
\hline Wait for Triage & LOGN $(15.3,14.8)$ & 0.003 \\
\hline Wait for Room & LOGN $(21.7,36.7)$ & 0.003 \\
\hline Wait for Visit & $0.5+49.5 *$ BETA $(0.629,1.68)$ & 0.012 \\
\hline
\end{tabular}

For a number of the processes and delays, there was not enough data to fit an appropriate distribution. In these instances, the triangular distribution was used. Kelton, Sadowski, and Sturrock (2007) state that the triangular distribution is commonly used in situations in which the exact form of the distribution is not known, but estimates for the minimum, maximum, and most likely values are available. Table III provides the remaining processes and delays with the minimum, maximum, and most likely values. 


\section{Table III}

Triangular Distribution Values for Processes/Delays

\begin{tabular}{|l|c|c|c|}
\hline \multicolumn{1}{|c|}{ Process/Delay } & Minimum & $\begin{array}{c}\text { Most } \\
\text { Likely }\end{array}$ & Maximum \\
\hline X-Ray Process & 6 & 7 & 15 \\
\hline Cat-Scan Process & 6 & 7 & 15 \\
\hline Procedure Room Process & 6 & 7 & 15 \\
\hline Registration Process & 1 & 2 & 3 \\
\hline Triage Process & 3 & 6 & 10 \\
\hline Technician Visits & 1 & 10 & 15 \\
\hline Wait for Nurse & 1 & 3 & 10 \\
\hline
\end{tabular}

Additionally, the x-ray, cat-scan, and procedure room process were assumed to have the same delay because there was not enough data available. Thus, it was assumed that these processes require similar amounts of times to complete.

Finally, the percentage of patients that require an x-ray, cat-scan, or procedure room was calculated, Table IV.

Table IV

Next Procedure Probabilities

\begin{tabular}{|l|c|}
\hline \multicolumn{1}{|c|}{ Procedure } & Percentage \\
\hline Stay in Room & $56.00 \%$ \\
\hline X-Ray & $14.50 \%$ \\
\hline Cat-Scan & $13.50 \%$ \\
\hline Procedure Room & $15.00 \%$ \\
\hline
\end{tabular}




\section{$\underline{\text { Simulation Model }}$}

This study required several different simulation models be created.

1. First, a simulation model of the current systems was made to get an accurate representation of the total amount of time a patient spends in the ED.

2. Then a model representing each of the two teaching methods was created.

3. After these three simulation models were created, each model was modified with an adjusted attending physician schedule. These six models were created to determine which teaching method would be most beneficial for Kosair Children's Hospital.

4. Data was then incorporated into the simulation models. An image of the final simulation can be seen in Appendix I.

The simulation begins with a create module that generates an entity, in this case, a patient. Patient arrivals were created based on a schedule of patients arriving to the emergency department during a particular time of the day. Table $\mathrm{V}$ provides the average number of patients that arrive in the emergency department in a day. Individual patient arrivals were assumed to be Poisson distributed with the mean number of arrivals shown in Table V. 
Table V

Patient Arrival Rates

\begin{tabular}{|c|c|}
\hline Time Period & Average Patients Per Hour \\
\hline 12 AM - 4 AM & 2 \\
\hline 4 AM - 8 AM & 0.72 \\
\hline 8 AM - 12 PM & 4.76 \\
\hline 12 PM - 4 PM & 5.04 \\
\hline 4 PM - 8 PM & 7.14 \\
\hline 8 PM - 12 AM & 6.97 \\
\hline
\end{tabular}

As soon as the patient entity arrives into the system it goes to a process module that represents the registration process. Next a delay module was used for the wait time until triage begins. A triage process module was then in cooperated followed by a delay module for the wait to go to the examination room. Figure III provides an illustration of the first section of the simulation model.

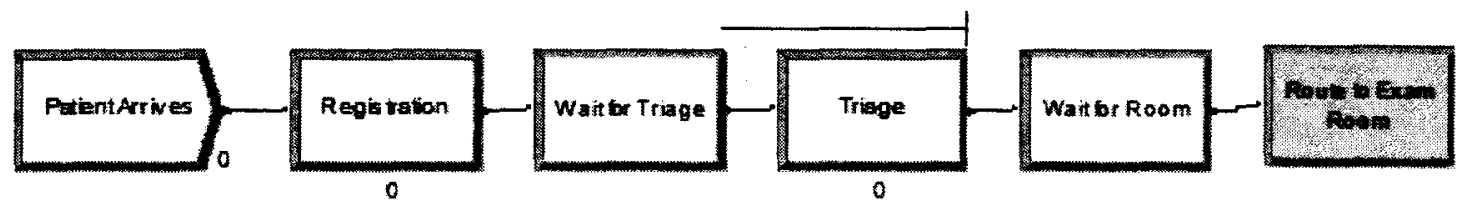

Figure III - Patients Arrive, Register, and were Triaged

The next step for the patient entity was to seize an exam room resource. This was done using the seize module. When a patient seizes an exam room, the room was not released back into the system until the patient leaves the emergency department. After a patient seizes an exam room, an assign module assigned an attribute and a variable to the patient. The attribute determined whether the patient needs to be sent to the procedure room, $\mathrm{X}$-ray, or cat-scan. A probability function was used to decide this. Table IV 
provides the probabilities that a patient will have one of the processes performed after their initial consultation.

Since this simulation was based on the total time that patient spends in the ED, it was imperative to get an accurate representation. To get this accurate representation of the time, the number of visits the patient has from one of the five staff members was counted from the collection of observations. Within the simulation, every time a patient was visited by a staff member, they begin a new loop through the system. A loop of the system consists of a staff member visiting the patient, and then the patient has the possibility of being sent to the x-ray, cat-scan, or procedure room. To determine the number of loops a patient makes, a triangular distribution was used with minimum value of six, most likely value of ten, and maximum value of thirteen visits. These values were determined based on the number of times a staff member visits the patient. This distribution was assigned to a variable that was decremented by one every time the patient starts a new loop. This continues until the variable reaches zero, in which time, the patient leaves the emergency department.

The delay module used represents the wait a patient incurs for a nurse to visit. It was observed in the emergency department that the first visit a patient experiences was always a nurse. After the initial nurse visit, the patient then waits again for the next visit from a staff member. Figure IV provides a representation of this portion of the model. 


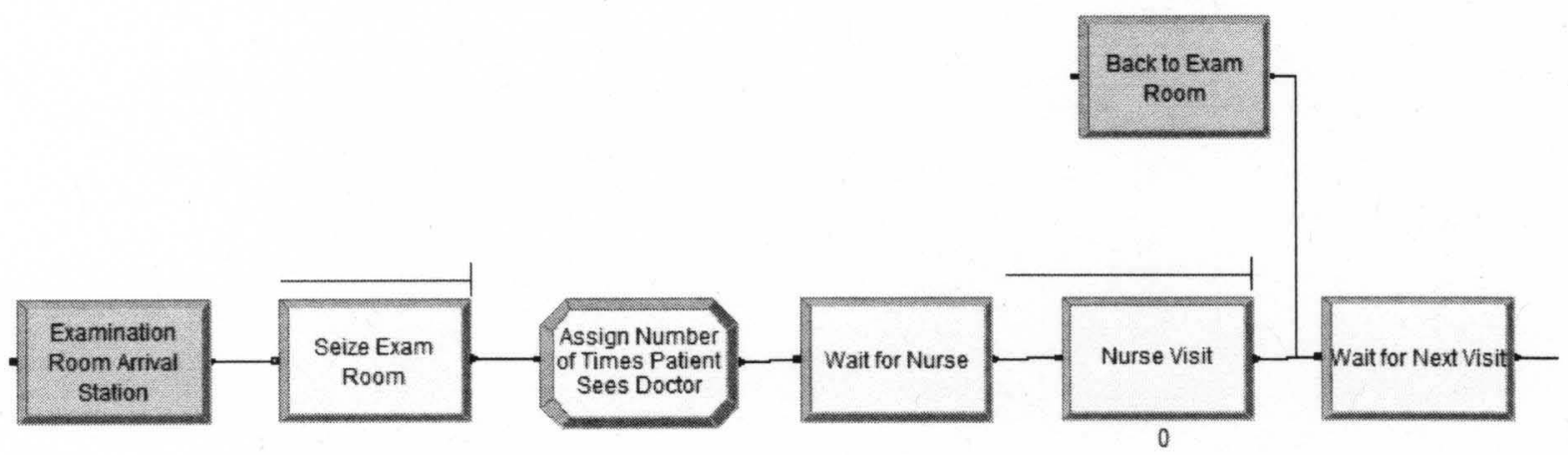

Figure IV - Patient Seizes Room, Assigned Attribute/Variable, and Nurse Visits

After the patient waits for a second time, he/she was then visited by another staff of the emergency department. The patient was visited next by one of five different staff members; including an attending physician, a resident physician, the nurse, the patient care associate (PCA), or a technician. Table VI provides the different probabilities for each staff to visit the patient based on the observations taken and Figure $\mathrm{V}$ provides the Arena $(C)$ model of this section.

Table VI

Percent of Next Staff Members

\begin{tabular}{|l|c|}
\hline \multicolumn{1}{|c|}{ Staff Member } & Percent Chance of Visit \\
\hline Nurse Visit & $29 \%$ \\
\hline Resident Visit & $27 \%$ \\
\hline Attending Visit & $25 \%$ \\
\hline PCA Visit & $15 \%$ \\
\hline Technician Visit & $4 \%$ \\
\hline
\end{tabular}




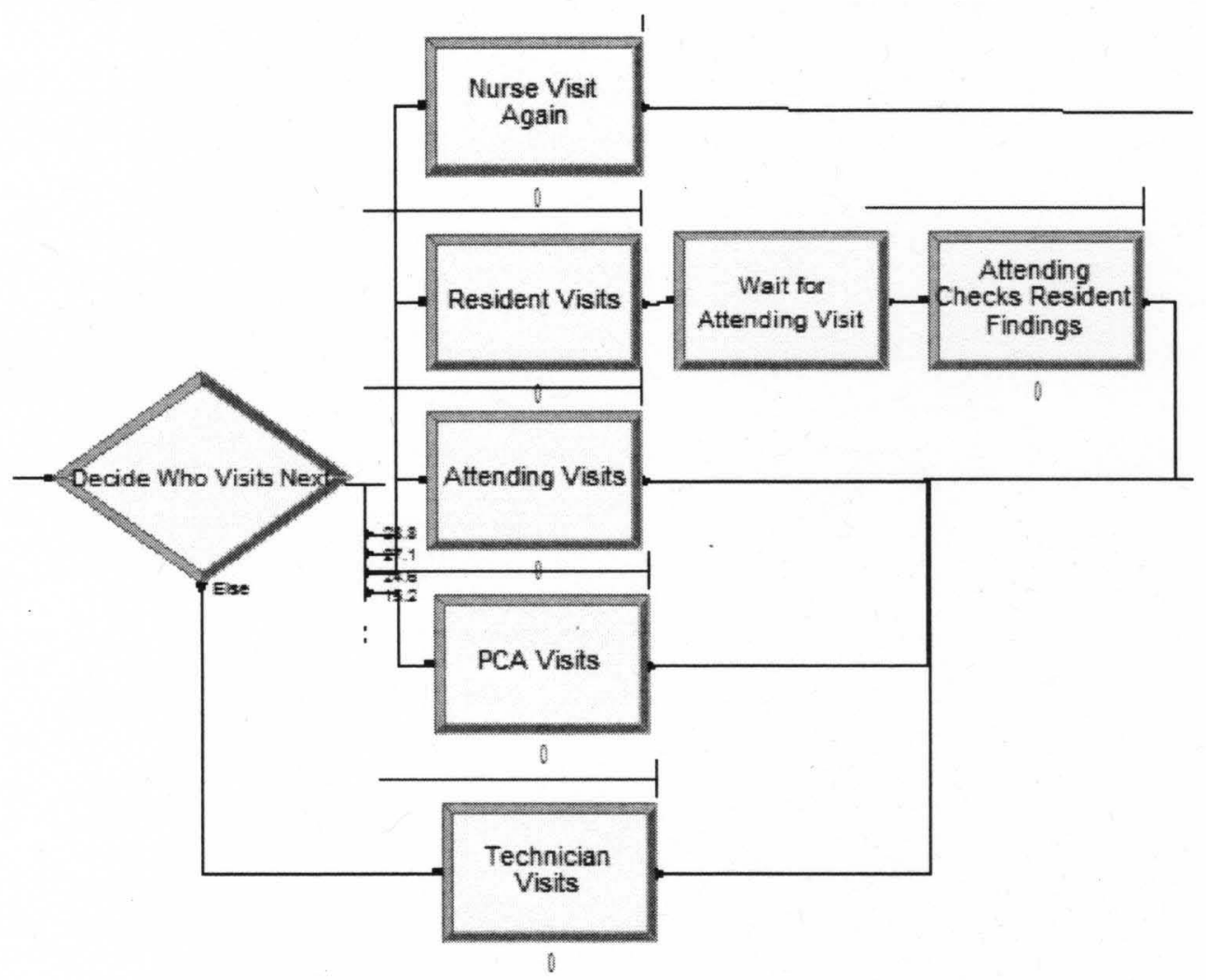

Figure V - Patient was Visited by a Staff Member

Staffing schedules were provided by Kosair for the emergency room for the attending physicians, resident physicians, nurses, and PCAs, which was included in the simulation model. The staffing levels vary depending on the time of the day. Less staff was typically needed in the morning hours, while the highest level of staffing was needed in the late afternoon to early evening time. Table VII provides staffing levels for an entire day at Kosair. 
Table VII

Staff Levels

\begin{tabular}{|r|c|c|c|c|}
\hline Time of Day & Attending & Resident & Nurses & PCA \\
\hline 12:00 AM & 3 & 4 & 12 & 5 \\
\hline 1:00 AM & 3 & 4 & 12 & 5 \\
\hline $2: 00 \mathrm{AM}$ & 3 & 4 & 12 & 5 \\
\hline 3:00 AM & 1 & 4 & 5 & 2 \\
\hline 4:00 AM & 1 & 2 & 5 & 2 \\
\hline 5:00 AM & 1 & 2 & 5 & 2 \\
\hline 6:00 AM & 1 & 2 & 5 & 2 \\
\hline 7:00 AM & 1 & 2 & 5 & 2 \\
\hline 8:00 AM & 1 & 2 & 5 & 2 \\
\hline 9:00 AM & 1 & 2 & 5 & 2 \\
\hline 10:00 AM & 2 & 2 & 5 & 2 \\
\hline $11: 00 \mathrm{AM}$ & 2 & 3 & 8 & 4 \\
\hline $12: 00 \mathrm{PM}$ & 2 & 3 & 8 & 4 \\
\hline $1: 00 \mathrm{PM}$ & 2 & 3 & 8 & 4 \\
\hline $2: 00 \mathrm{PM}$ & 2 & 4 & 8 & 4 \\
\hline 3:00 PM & 2 & 4 & 9 & 5 \\
\hline $4: 00 \mathrm{PM}$ & 2 & 4 & 9 & 5 \\
\hline $5: 00 \mathrm{PM}$ & 2 & 4 & 9 & 5 \\
\hline $6: 00 \mathrm{PM}$ & 2 & 4 & 9 & 5 \\
\hline $7: 00 \mathrm{PM}$ & 2 & 4 & 12 & 5 \\
\hline 8:00 PM & 2 & 4 & 12 & 5 \\
\hline 9:00 PM & 2 & 4 & 12 & 5 \\
\hline 10:00 PM & 2 & 4 & 12 & 5 \\
\hline $11: 00 \mathrm{PM}$ & 3 & 4 & 12 & 5 \\
\hline & & & & \\
\hline
\end{tabular}

Also, if the patient was visited by the resident physician, then the patient must incur another wait and was visited by the attending physician, Figure V. This allowed the attending physician to check the diagnosis and work of the resident.

After the patient was visited by a staff member, a decision module was used to determine if the patient needs to have an $\mathrm{x}$-ray, cat-scan, go to the procedure room, or stay in their room. The decide module uses the attribute that was assigned earlier in the 
model to determine this. If it was decided that the patient goes to $\mathrm{x}$-ray, cat-scan, or the procedure room, a counter increases by one for each procedure and then the patient was transferred to the respective area. If the patient does not go to any of the areas, he/she stays in their room and continues on through the system. Figure VI illustrates the patient's visits to x-ray, cat-scan, and procedure room, if any.

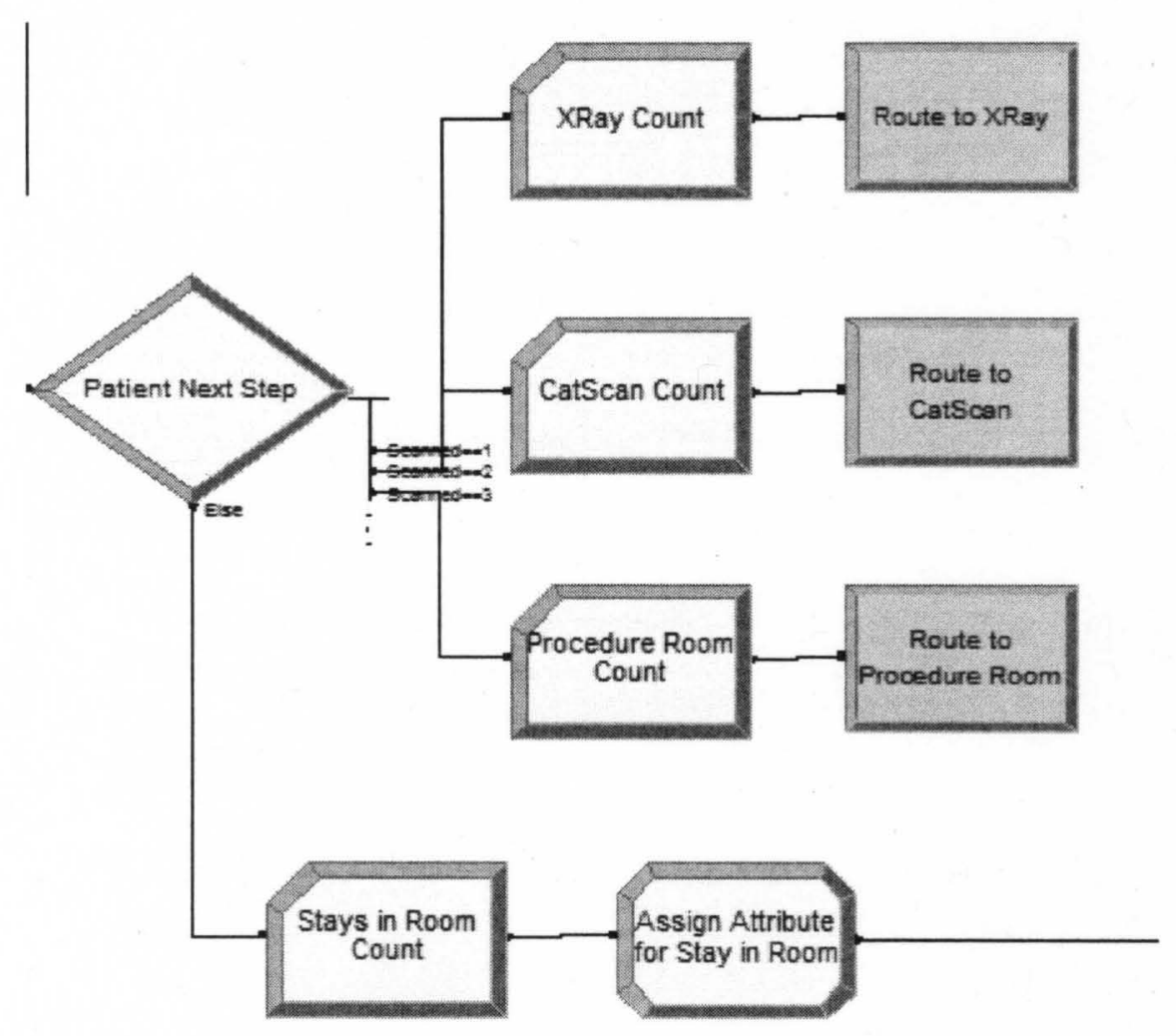

Figure VI - Decision on Where the Patient Goes Next

The next step for the patient was to actually go to the $\mathrm{x}$-ray, cat-scan, or procedure room. Here, process modules represent each of the tasks. After the patient completes the process, an assignment module adjusted the attribute that was assigned to the patient earlier. The attribute was changed to ensure that the patient does not make a return trip to the same process and to ensure that it was highly unlikely they will have another process 
assigned to them after they have already had one, as observed in the ED. This portion of the model is represented in Figure VII.
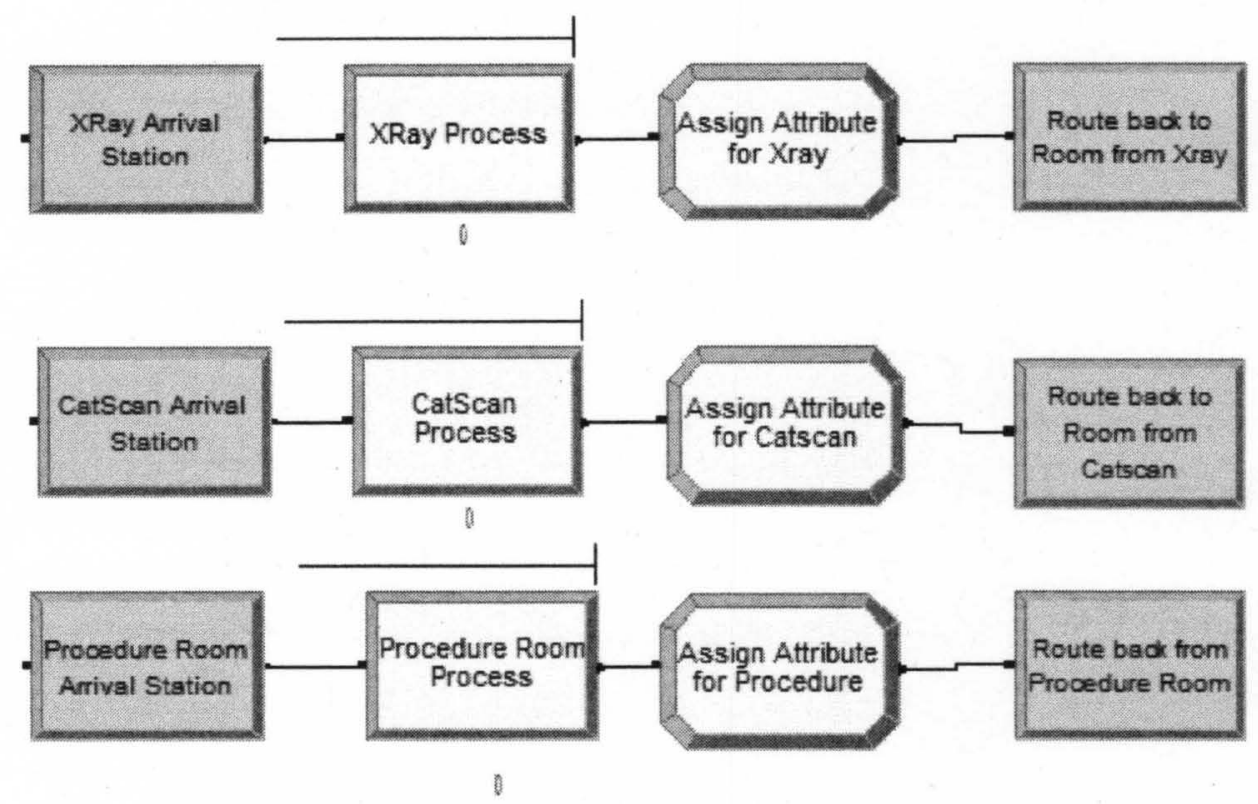

Figure VII - X-Ray, Cat-Scan, and Procedure Room Process

After the patient entity completes the x-ray, cat-scan, or procedure room process if necessary, or if the patient stayed in their ED examination room a decision needed to be made on whether or not the patient will leave the emergency department. This was done based on the earlier looping variable that was assigned to the patient. If the variable had not been reduced to 0 , the patient makes another loop through the system. If the patient's variable counter had reached 0 , then the patient was visited a last time by the nurse. This final visit by a nurse was observed for every patient, as it was the time the nurse provides the patient with final instructions. This portion of the model is represented below in Figure VIII. 


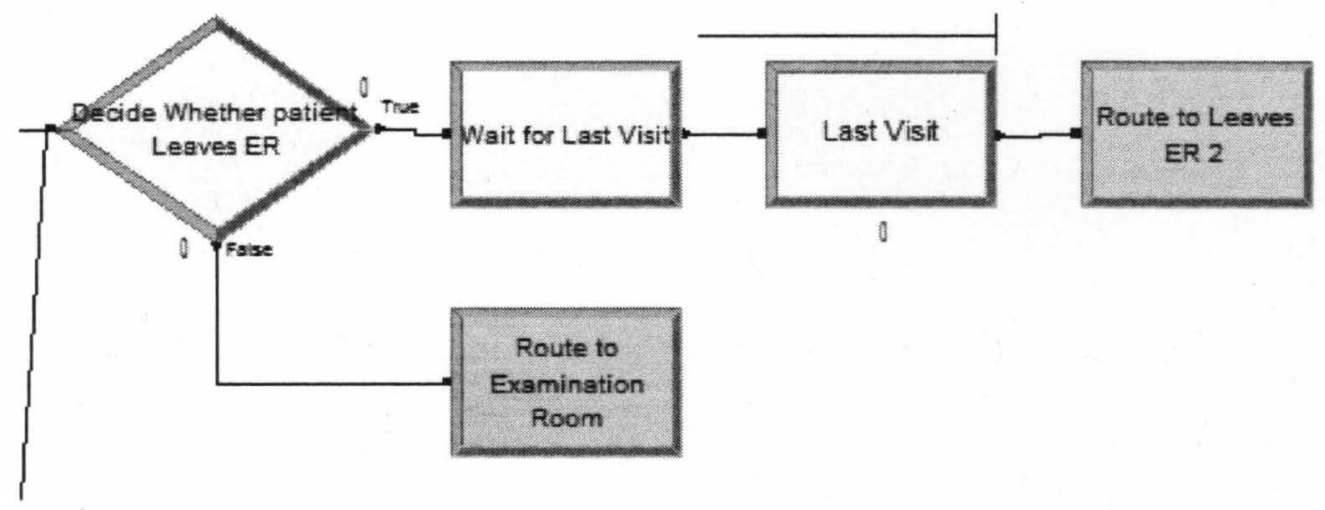

Figure VIII - Patient Reroutes Through the System or has Last Visit After the patient's final nurse visit, the patient leaves the system. A record module records the total number of patients that leave the system. A release module was used to release the exam room resource that was seized at the beginning of the model. Finally, a dispose module was used for the patient to leave the system. These final modules are represented in Figure IX.

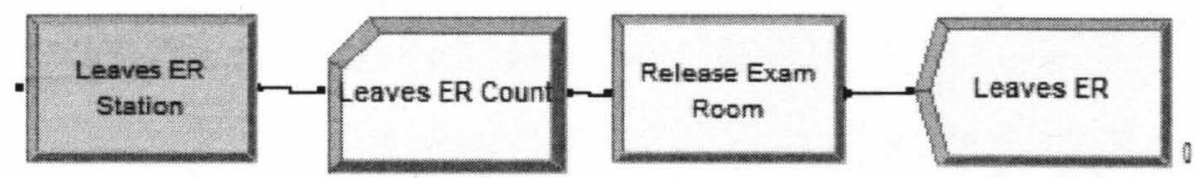

Figure IX - Exam Room was Released and Patient Leaves

\section{Model Verification and Validation}

After the simulation model was completed, the steps of model verification and validation were performed. Rossetti et al. (1999) state, "Verification is the process of ensuring that the simulation model is built correctly and performs as the modeler intended," and "Validation is the process of ensuring that the model is an accurate representation of the actual system and behaves in the same way." According to Averill 
M. Law (2007), there are eight different techniques to verify a simulation model. Of the eight techniques, two were used to verify this model. Technique two suggests having another person knowledgeable about the system walk through the program step-by-step (this is also a form of validation). This was done with a research colleague, who also shared observation times/notes. Technique seven was selected based on its use of quantitative methods. Specifically, comparing sample means and sample variances with historical means and variances. Since this model's purpose was to reduce a patient's length of stay in the system, this specific result was used to verify and validate the model. The historic data shows that the average patient time in the system was 277 minutes. The simulation model was run with 10 replications with a length of 90 days each. With these parameters, the average length in the system was calculated to be 283.83 minutes, with a $95 \%$ confidence interval length of stay to be between 269.57 and 306.26 minutes. Since the calculated time from the Arena $(C$ model was within $2.5 \%$, it was determined to be an accurate representation of the actual emergency department at Kosair Children's Hospital.

\section{Testing Alternative Methods}

Once the simulation model of the current ED was verified and validated, it was used to determine if alternate teaching methods would be beneficial. The first method that was tested was the teach only attending method discussed earlier. This method dedicates an attending physician to work with the resident physicians. The attending accompanies the resident when he/she performs any task with a patient. 
To model this, the only change to the original model that needed to be made was the addition of another resource to the process module for the resident physician. A separate resource, namely, the teach only physician, was added. Figure $\mathrm{X}$ below provides a point of reference as to where in the model this action takes place.

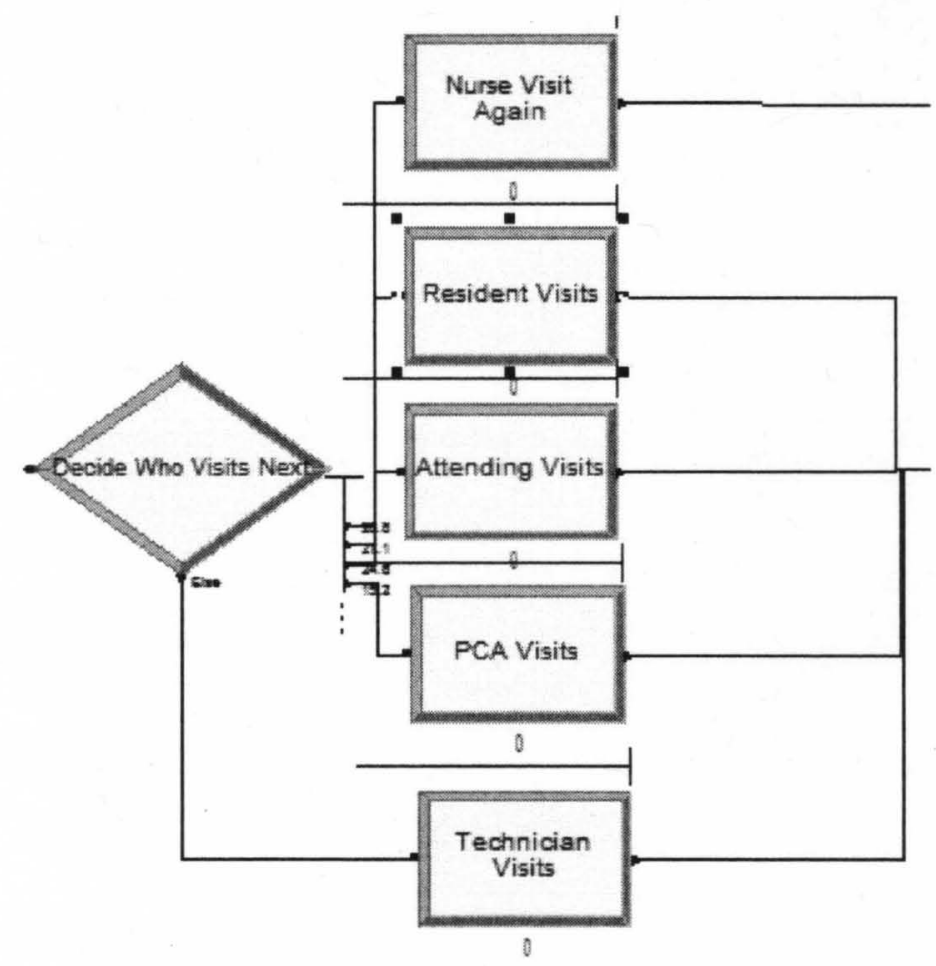

Figure X - Teach Only Attending

The second method of teaching that was tested was the method of having an attending go with the resident physician at all times when they visit a patient. This method was accomplished by adjusting the same portion of the original model. For this method, the resident module was deleted and within the attending physician module, both the attending and the resident resource were used when a patient enters the module. Table IV was updated to correspond with the changes made. A representation of this portion of the model can be seen in Figure XI. 


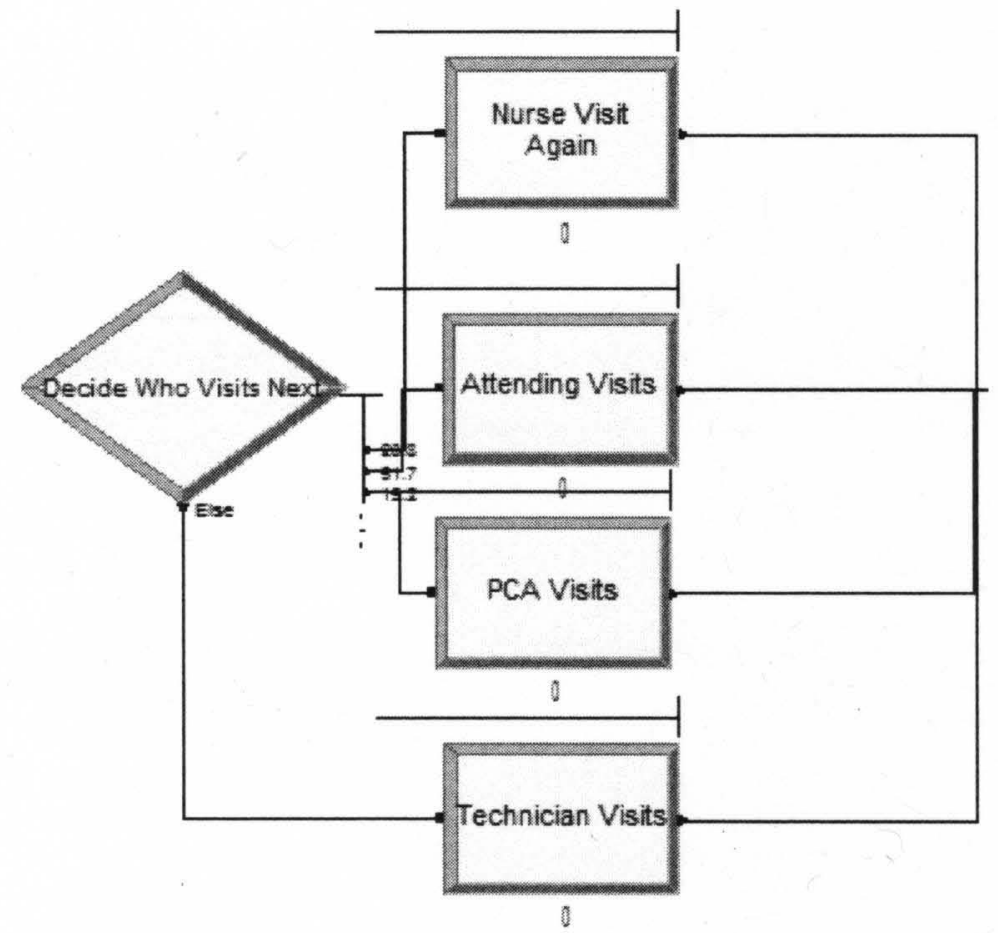

Figure XI - Resident with Attending

A final adjustment that was made concerns the number of attending physicians that were available at given points during the day. Different levels of attending physicians were tested for different times of the day to determine the optimal attending staff level. The results of this method and the rest of the changes mentioned above are explained in detail in the next section. 


\section{RESULTS}

The simulation model of the current emergency department operations was executed for 10 replications each with a length of 90 days. The average patient time in the emergency department was 283.83 minutes. The wait time for the patients for the attending physician was found to be about 27.7 minutes and the utilization of the attending physician was determined to be $75.69 \%$. The utilization was calculated as a percentage of the time a resource was being used.

After the initial model was run, the two different teaching method models were run to determine if either method was more efficient for decreasing the patients wait time. The full Arena@ output files can be seen in Appendix II, III and IV for the current, teach only method, and the resident with an attending method respectively. For an easier summary, the following table, Table VIII, provides the important and useful information.

Table VIII

Results of Current and Two Different Teaching Methods

\begin{tabular}{|c|c|c|c|c|c|}
\hline Method & $\begin{array}{c}\text { Total } \\
\text { Time }\end{array}$ & $\begin{array}{c}\text { Minutes } \\
\text { Decrease from } \\
\text { Current }\end{array}$ & $\begin{array}{c}\text { \% Decrease } \\
\text { in Total } \\
\text { Time }\end{array}$ & $\begin{array}{c}\text { Avg. Wait for } \\
\text { Attending }\end{array}$ & $\begin{array}{c}\text { Attending } \\
\text { Utilization }\end{array}$ \\
\hline Current & 283.83 & 0.00 & 0.00 & 27.7 & 75.69 \\
\hline Teach Only & 270.94 & 12.89 & 4.54 & 2.4 & $37.77 *$ \\
\hline $\begin{array}{c}\text { Resident with } \\
\text { Attending }\end{array}$ & 263.07 & 20.76 & 7.31 & 31.68 & 76.40 \\
\hline
\end{tabular}

*Note: This was average utilization for non-teaching attending physicians

All three of these simulation models were run with the staff schedule provided in Table VII. It can be seen from Table VIII that the teach only method has a $4.5 \%$ decrease 
in the overall time. This method does lower the average attending utilization significantly, and while this could be beneficial at times, it was not in this instance because it lowered it too much. A $37.77 \%$ utilization was not desirable because there were resources, in this case the non-teaching attending physicians, which were often not busy. The average utilization of the teach only attending was $77.76 \%$. A reduction in the number of non-teaching attending physicians could have been tested but this would have had little effect of the reduction of the patient's total time in the system, so this was not performed.

The method of having an attending physician with a resident physician at all times does provides the best results with a reduction in patient wait time of approximately $7 \%$. While this was an improvement, it was not a significant improvement, so it was decided that a change needed to be made elsewhere.

When creating the simulation, and in particular, when creating the schedules for the attending physicians, it was noticed that there seemed to be a lack of attending physicians staffed at the time of day that has the greatest influx of patients entering the ED. There were only two attending physicians scheduled starting at 10:00 AM through 11:00 PM at which time the level was raised to three attending physicians until 3:00 AM. It was discovered in creating the create module that the highest volume of patients enter the emergency department starting around 12:00 PM and continue until 12:00 AM. Thus, it was decided that the staff level for the attending physician would be changed and tested to determine what level was best for the emergency department.

To determine the best staff level for the attending physicians, the levels were changed from two physicians to three physicians starting at 10:00 PM and working 
backwards hour by hour till 12:00 PM. The total time in the system for patients and the attending utilization were collected for each hour to help determine exactly what time the attending physician level should be increased from two to three. For example, at 10:00 PM the attending physician level was changed from two to three and the model was run. The attending physician utilization was $73.69 \%$ and the total time in the system for the patient was 268.24 minutes. Next, the physician level was changed from two to three at 9:00 PM and the utilization was found to be $72.51 \%$ and the total time for the patient was 260.88 minutes. This continues until 12:00 PM. Table IX below shows the data collected for each hour.

Table IX

Adjustments to Attending Staff Schedule

\begin{tabular}{|c|c|c|}
\hline Time Period & $\begin{array}{c}\text { Total } \\
\text { Time }\end{array}$ & $\begin{array}{c}\text { Attending Physician } \\
\text { Utilization }\end{array}$ \\
\hline Current Staff Level & 283.83 & 75.69 \\
\hline 10:00 PM & 268.24 & 73.69 \\
\hline 9:00 PM & 260.88 & 72.51 \\
\hline $8: 00 \mathrm{PM}$ & 252.90 & 71.00 \\
\hline $7: 00 \mathrm{PM}$ & 246.44 & 69.64 \\
\hline $6: 00 \mathrm{PM}$ & 239.73 & 68.78 \\
\hline $5: 00 \mathrm{PM}$ & 234.75 & 67.66 \\
\hline $4: 00 \mathrm{PM}$ & 231.09 & 66.00 \\
\hline $3: 00 \mathrm{PM}$ & 226.74 & 64.55 \\
\hline $2: 00 \mathrm{PM}$ & 223.92 & 63.81 \\
\hline 1:00 PM & 222.86 & 62.86 \\
\hline $12: 00 \mathrm{PM}$ & 221.94 & 61.56 \\
\hline
\end{tabular}

It can be seen from Table IX that as the staff level for the attending physician is increased from two to three for each hour, the total time in the system decreases. While this was what the goal was for this study, the utilization needs to be considered. As 
stated before, a low utilization was not beneficial to a system in that it means there were resources that were not being used. That was why it was decided that the best time for the staff level to be raised from two to three was 3:00 PM. Running the simulation with the change from 4:00 to 3:00 reduced the total time in the system by 4.35 minutes and the utilization only lowered by 0.014 and since the next run from 3:00 to 2:00 only dropped the overall time by 2.82 minutes, it was decided that 3:00 PM would be sufficient.

After 3:00 PM was decided to be the best time of day to increase the attending physician staffing schedule, all three models (current, teach only attending, and attending with resident) were run again with the modification. Table $\mathrm{X}$ contains the results of all three models with the new staff schedule for attending physicians and Appendices V, VI. VII provide the full ArenaC results.

Table X

Results of Teaching Methods with New Staff Level

\begin{tabular}{|c|c|c|c|c|c|}
\hline Method & $\begin{array}{c}\text { Total } \\
\text { Time }\end{array}$ & $\begin{array}{c}\text { Minutes } \\
\text { Decrease from } \\
\text { Current }\end{array}$ & $\begin{array}{c}\text { \% } \\
\text { Decrease in } \\
\text { Total Time }\end{array}$ & $\begin{array}{c}\text { Avg. Wait } \\
\text { for } \\
\text { Attending }\end{array}$ & $\begin{array}{c}\text { Attending } \\
\text { Utilization }\end{array}$ \\
\hline New Current & 226.74 & 57.09 & 20.11 & 9.4 & 64.55 \\
\hline Teach Only & 268.15 & 15.68 & 5.52 & 1.35 & 32.19 \\
\hline $\begin{array}{c}\text { Resident with } \\
\text { Attending }\end{array}$ & 204.03 & 79.8 & 28.12 & 11.59 & 65.42 \\
\hline
\end{tabular}

As shown in Table $\mathrm{X}$ the teach only method provided a $5.5 \%$ decrease in total time in the ED from the original model (283.83 minutes) of the current ED operation. Much like the first teach only method with no change to the staff schedule, this teach only method has a small percent decrease of the overall total time. Again, like the first run of this method, there was a significantly low utilization for the attending physician which was not desired. 
The adjustment of the attending physician's staff level to the current operation of the ED produced a reduction in time of 57 minutes or $20 \%$. The utilization for the attending physicians for this method was $64.55 \%$ which was an acceptable level. Also, the average wait for the patients to see the physicians for this method was calculated to be 9.4 minutes which was almost an 18 minute reduction from 27.7 minutes from the current method.

The other teaching method, having an attending physician with a resident physician at all times produced the best results. This method without adjustments to the attending staff level produced a reduction of time by $7 \%$ and with the adjustments it produced a reduction of time of $28 \%$. This $28 \%$ reduction of total time was equivalent to an 80 minute reduction. The utilization of the attending physician for this method was $65.42 \%$ which was within acceptable levels. 


\section{RECOMMENDATIONS}

The recommendations chapter will discuss the benefits that adjusting the staff level for the attending physicians and the method of teaching in which an attending physician will be with a resident at all times will have on the total time that patients spend in the emergency department at Kosair Children's Hospital.

Based on the results, the first recommendation to be made is to implement the extra hours for the attending physicians. If there were 3 attending physicians on staff starting at 3:00 PM until 11:00 PM, then the patient's time in the system could be reduced by $20 \%$ or 57 minutes. The increase of the attending level from 2 to 3 from 3:00 PM to 10:00 PM is equivalent to an 8 hour shift. To cover these extra 8 hours, another attending physician could be hired or the current attending physicians could pick up extra hours each day if possible. The hiring of another attending physician obviously requires more money to be spent for the salary of the new physician; however, it is believed that the money would be well spent because patients would spend a significantly less amount of time in the emergency room.

The second recommendation is to change the current teaching method to the method of always having an attending physician with a resident physician at the time of the patient visit. This eliminates the extra time wasted when the resident has to report back to the attending after every visit with a patient. If this teaching method could be implemented in Kosair Children's Hospital, along with the change in attending 
physician staff, there is the potential for the hospital to reduce the patient's time through the system by $28 \%$ or nearly 80 minutes. This reduction in total time equates to 204 minutes for patients to travel through the system. This reduction would most certainly help Kosair to increase the satisfaction scores to desirable levels. This recommendation does require a major change to take place within the emergency department and with the protocols associated with the teaching and training of the resident physicians. However, if new teaching protocols were created and implemented with little confusion, then the change is definitely worth the time spent and training needed that would be required to make these changes.

Both of these recommendations require that change happen within the emergency department of Kosair Hospital. Nevertheless, it is believed that the results from the changes greatly outweigh the time and money required to make said changes. Thus, it is believed that for Kosair to increase their patient's satisfaction, it would be greatly beneficial for them to make the recommended changes. 


\section{CONCLUSIONS AND FUTURE RESEARCH}

Kosair Children's Hospital's study objective was to increase their patient satisfaction goal by means of decreasing the amount of time patients spend in the emergency department. By implementing a new staff level for the attending physicians or by changing the methods of teaching the resident physicians, the hospital could potentially reduce the length of stay of the their patients by $20 \%$ and $28 \%$ respectively.

Kosair can continue to improve their emergency department through a number of different ways. First, the computer simulation that was used in this study could be expanded even more. There were a number of factors that were excluded from this study that could be included in future models. For instance, creating a simulation model that allows patients to enter the ED from either the waiting room or an ambulance would represent the actual emergency department even more accurately.

Another factor that could be added to the simulation is the attribute of the patients which is based on acuity level. In Kosair Hospital, there were 5 different levels of acuity that were used to classify patients. The higher acuity patients have a higher priority throughout their stay. This aspect was left out of this current simulation simply because the data that was given did not provide this information for each patient that was needed to model these patient acuities. 
The next item that could be added to the simulation is more accurate data. Some of the timings in this study were based on a small amount of data while others were based on a significantly larger number of data. If large amounts of data were used to calculate all of the timings then the simulation would use timings that were even representative of what is actually happen.

Another factor that could be taken in to consideration and added to the simulation is the Kids Express. The Kids Express provides an opportunity for patients with less severe conditions another method for getting treatment. When the Kids Express was not open, these patients proceeded through the emergency department like everyone else. Since this has an effect on the emergency department, modeling this within the simulation would provide a more accurate representation of the emergency department. Finally, the last thing that could be done to help continually improve Kosair is after Kosair implements any of the recommendations; have the simulation adjusted to mirror the new emergency department. Once this is done, even more adjustments could be researched to determine if the emergency department could improve even more. 
REFERENCES 
Aldeen, A. Z., \& Gisondi, M. A. (2006). Bedside Teaching in the Emergency Department. Educational Advances, 860-866.

Anderson, R. T., Camacho, F. T., \& Balkrishnan, R. (2007). Willing to wait?: The influence of patient wait on satisfaction with primary care. BMC Health Services Research.

Arena. (n.d.). 13. Wexford, Pennsylvania: Rockwell Automation.

Atlason, J., Epelman, M. A., \& Henderson, S. G. (2004). Call Center Staffing with Simulation and Cutting Plane Methods. Annals of Operations Research, 333-358.

Boudreaux, E. D., Ary, R. D., Mandry, C. V., \& McCabe, B. (2000). Determinants of Patient Satisfaction in a Large, Municipal ED: The Role of Demographic Variables, Visit Charavteristics, and Patient Perceptions. American Journal of Emergency Medicine, 394-400.

Centeno, M. A., Giachetti, R., Linn, R., \& Ismail, A. M. (2003). A Simulation-ILP Based Tool for Scheduling ER Staff. 2003 Winter Simulation Conference, (pp. 19301938).

Centers for Disease Control and Prevention. (2009, December). Summary Health Statistics for U.S. Children: National Health Interview Survey, 2008. Retrieved September 27, 2010, from Centers for Disease Control and Prevention: http://www.cdc.gov/nchs/data/series/sr_10/sr10_244.pdf

Chisholm, C. D., Whenmouth, L. F., Daly, E. A., Cordell, W. H., Giles, B. K., \& Brizendine, E. J. (2004). An Evaluation of Emergency Medicine Resident Interaction Time with Faculty in Different Teaching Venues. Academic Emergency Medicine, 149-155.

Dengiz, B. (2009). Redesign of PCB Production Line with Simulation and Taguchi Design. Proceedings of the 2009 Winter Simulation Conference, 2197-2204.

Draeger, M. A. (1992). An Emergency Department Simulatino Model Used to Evaluate Alternative Nurse Staffing and Patient Population Scenarios. 1992 Winter Simulation Conference, (pp. 1057-1064).

Evans, G. W., Gor, T. B., \& Unger, E. (1996). A Simulation Model for Evaluating Personnel Schedules in a Hospital Emergency Department. 1996 Winter Simulation Conference, (pp. 1205-1209).

Gentry, E. (2009). Analysis of Patient Throughput Time at Kosair Children's Hospital Emergency Room. 
Jun, J. B., Jacobson, S. H., \& Swisher, J. (1999). Applications of Discrete-Event Simulation in Health Care Clinics: A Survey. The Journal of the Operational Research Society, 50(2), 109-123.

Kelton, W. D., Sadowski, R. P., \& Sturrock, D. T. (2007). Simulation with Arena (4th ed.). New York: McGraw-Hill.

Law, A. M. (2007). Simulation Modeling \& Analysis. New York: McGraw-Hill.

Nawar, E. W., Niska, R. W., \& Xu, J. (2007). Hospital Ambulatory Medical Care Survey: 2005 Emergency Department Summary. Vital and Health Statistics.

Rossetti, M. D. (2010). Simulation Modeling and Arena. Hoboken: John Wiley \& Sons.

Rossetti, M. D., Trzcinski, G. F., \& Syverud, S. A. (1999). Emergency Department Simulation and Determination of Optimal Attending Physician Staffing Schedules. 1999 Winter Simulation Conference, (pp. 1532-1540).

Samaha, S., Aremel, W. S., \& Starks, D. W. (2003). The Use of simulation to Reduce the Length of Stay in an Emergency Department. 2003 Winter Simulation Conference, (pp. 1907-1911).

Thompson, D. A., \& Yarnold, P. R. (1995). Relating Patient Satisfaction to Waiting Time Perceptions and Expectations: The Disconfirmation Paradigm. Academic Emergency Medicine, 1057-1062.

University of Louisville/Kosair Children's Hospital. (n.d.). Retrieved September 27, 2010, from PPRU Pediatric Pharmacology Research Unit Network: http://www.ppru.org/louisville.html

Yeh, J.-Y., \& Lin, W.-S. (2007). Using simulation technique and genetic algorithm to improve the quality care of a hospital emergency department. Expert systems with Applications, 1073-1083. 


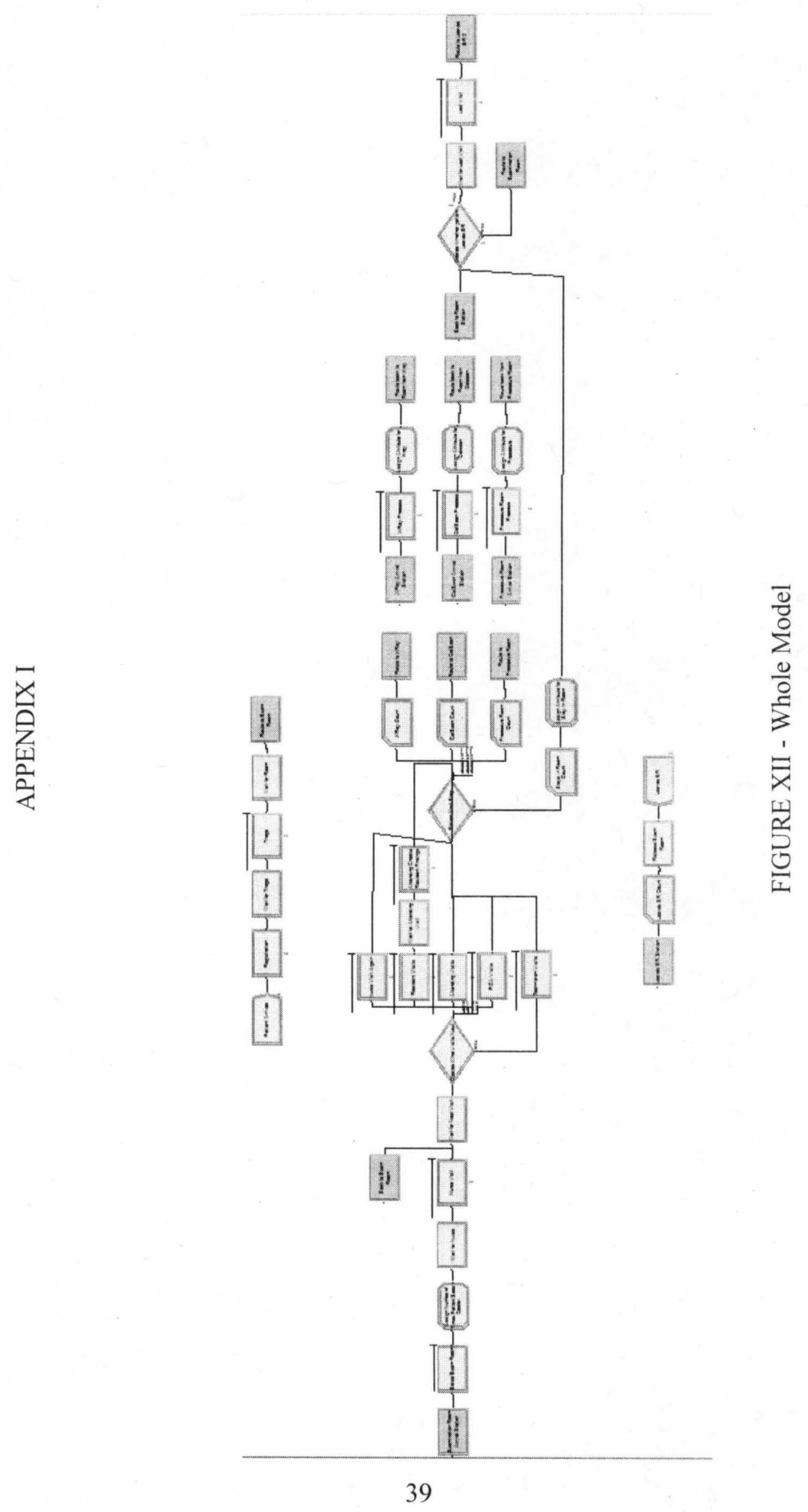


APPENDIX II

ARENA RESULTS FOR ORGINAL MODEL 
Kosairs ER Simulation

Replications:

10

Time Units:

Minutes

Key Performance Indicators

\section{System}

Number Out
Average

9,255 
values Across All Replications

Kosairs ER Simulation

Replications: 10 Time Units: Minutes

\section{Entity}

\section{Time}

\begin{tabular}{|c|c|c|c|c|c|c|}
\hline VA Time & Average & Half Width & $\begin{array}{c}\text { Minimum } \\
\text { Average }\end{array}$ & $\begin{array}{c}\text { Maximum } \\
\text { Average }\end{array}$ & $\begin{array}{c}\text { Minimum } \\
\text { Value }\end{array}$ & $\begin{array}{c}\text { Maximum } \\
\text { Value }\end{array}$ \\
\hline Patient 1 & 56.0696 & 0.26 & 55.6397 & 56.7190 & 7.9148 & 415.42 \\
\hline NVA Time & Average & Half Width & $\begin{array}{c}\text { Minimum } \\
\text { Average }\end{array}$ & $\begin{array}{r}\text { Maximum } \\
\text { Average }\end{array}$ & $\begin{array}{c}\text { Minimum } \\
\text { Value }\end{array}$ & $\begin{array}{l}\text { Maximum } \\
\text { Value }\end{array}$ \\
\hline Patient 1 & 0.00 & 0.00 & 0.00 & 0.00 & 0.00 & 0.00 \\
\hline Wait Time & Average & Half Width & $\begin{array}{c}\text { Minimum } \\
\text { Average }\end{array}$ & $\begin{array}{c}\text { Maximum } \\
\text { Average }\end{array}$ & $\begin{array}{c}\text { Minimum } \\
\text { Value }\end{array}$ & $\begin{array}{c}\text { Maximum } \\
\text { Value }\end{array}$ \\
\hline Patient 1 & 225.10 & 6.61 & 210.92 & 246.87 & 11.1238 & 2031.44 \\
\hline Transfer Time & Average & Half Width & $\begin{array}{c}\text { Minimum } \\
\text { Average }\end{array}$ & $\begin{array}{c}\text { Maximum } \\
\text { Average }\end{array}$ & $\begin{array}{c}\text { Minimum } \\
\text { Value }\end{array}$ & $\begin{array}{c}\text { Maximum } \\
\text { Value }\end{array}$ \\
\hline Patient 1 & 2.6639 & 0.01 & 2.6511 & 2.6745 & 2.0000 & 8.0000 \\
\hline Other Time & Average & Half Width & $\begin{array}{c}\text { Minimum } \\
\text { Average }\end{array}$ & $\begin{array}{c}\text { Maximum } \\
\text { Average }\end{array}$ & $\begin{array}{c}\text { Minimum } \\
\text { Value }\end{array}$ & $\begin{array}{c}\text { Maximum } \\
\text { Value }\end{array}$ \\
\hline Patient 1 & 0.00 & 0.00 & 0.00 & 0.00 & 0.00 & 0.00 \\
\hline Total Time & Average & Half Width & $\begin{array}{c}\text { Minimum } \\
\text { Average }\end{array}$ & $\begin{array}{r}\text { Maximum } \\
\text { Average }\end{array}$ & $\begin{array}{c}\text { Minimum } \\
\text { Value }\end{array}$ & $\begin{array}{l}\text { Maximum } \\
\text { Value }\end{array}$ \\
\hline Patient 1 & 283.83 & 6.80 & 269.57 & 306.26 & 29.8049 & 2324.76 \\
\hline
\end{tabular}

\section{Other}

\begin{tabular}{|c|c|c|c|c|c|c|}
\hline Number In & Average & Half Width & $\begin{array}{c}\text { Minimum } \\
\text { Average }\end{array}$ & $\begin{array}{r}\text { Maximum } \\
\text { Average }\end{array}$ & & \\
\hline Patient 1 & 9256.60 & 68.24 & 9093.00 & 9376.00 & & \\
\hline Number Out & Average & Half Width & $\begin{array}{c}\text { Minimum } \\
\text { Average }\end{array}$ & $\begin{array}{r}\text { Maximum } \\
\text { Average }\end{array}$ & & \\
\hline Patient 1 & 9255.30 & 67.91 & 9095.00 & 9377.00 & & \\
\hline WIP & Average & Half Width & $\begin{array}{c}\text { Minimum } \\
\text { Average }\end{array}$ & $\begin{array}{r}\text { Maximum } \\
\text { Average }\end{array}$ & $\begin{array}{c}\text { Minimum } \\
\text { Value }\end{array}$ & $\begin{array}{l}\text { Maximum } \\
\text { Value }\end{array}$ \\
\hline Patient 1 & 20.9716 & 0.58 & 19.5753 & 22.9011 & 0.00 & 79.0000 \\
\hline
\end{tabular}




\section{Kosairs ER Simulation}

Replications: 10 Time Units: Minutes

\section{Queue}

\section{Time}

\begin{tabular}{|c|c|c|c|c|c|c|}
\hline Waiting Time & Average & Half Width & $\begin{array}{c}\text { Minimum } \\
\text { Average }\end{array}$ & $\begin{array}{c}\text { Maximum } \\
\text { Average }\end{array}$ & $\begin{array}{c}\text { Minimum } \\
\text { Value }\end{array}$ & $\begin{array}{l}\text { Maximum } \\
\text { Value }\end{array}$ \\
\hline $\begin{array}{l}\text { Attending Checks Resident } \\
\text { Findings. Queue }\end{array}$ & 27.7899 & 1.38 & 24.3769 & 32.2127 & 0.00 & 260.88 \\
\hline Attending Visits.Queue & 27.5550 & 1.52 & 23.7851 & 32.1533 & 0.00 & 255.09 \\
\hline CatScan Process.Queue & 0.6505 & 0.04 & 0.5852 & 0.7714 & 0.00 & 29.0105 \\
\hline Last Visit.Queue & 0.00025929 & 0.00 & 0.00 & 0.00103757 & 0.00 & 1.9631 \\
\hline Nurse Visit Again.Queue & 0.00009235 & 0.00 & 0.00 & 0.00035361 & 0.00 & 1.8517 \\
\hline Nurse Visit.Queue & 0.00010594 & 0.00 & 0.00 & 0.00033793 & 0.00 & 1.7668 \\
\hline PCA Visits.Queue & 0.00341234 & 0.00 & 0.00087303 & 0.00933406 & 0.00 & 6.8227 \\
\hline Procedure Room Process.Queue & 0.02404576 & 0.00 & 0.01374755 & 0.03491487 & 0.00 & 9.3944 \\
\hline Resident Visits.Queue & 0.1425 & 0.01 & 0.1144 & 0.1735 & 0.00 & 28.7400 \\
\hline Seize Exam Room.Queue & 16.0284 & 2.72 & 10.0482 & 24.9841 & 0.00 & 404.58 \\
\hline Technician Visits.Queue & 0.9642 & 0.05 & 0.8406 & 1.0707 & 0.00 & 35.4974 \\
\hline Triage.Queue & 0.4057 & 0.02 & 0.3640 & 0.4306 & 0.00 & 22.8737 \\
\hline XRay Process.Queve & 0.7086 & 0.05 & 0.5893 & 0.8401 & 0.00 & 31.4370 \\
\hline \multicolumn{7}{|l|}{ Other } \\
\hline Number Waiting & Average & Half Width & $\begin{array}{l}\text { Minimum } \\
\text { Average }\end{array}$ & $\begin{array}{c}\text { Maximum } \\
\text { Average }\end{array}$ & $\begin{array}{l}\text { Minimum } \\
\text { Value }\end{array}$ & $\begin{array}{r}\text { Maximum } \\
\text { Value }\end{array}$ \\
\hline $\begin{array}{l}\text { Attending Checks Resident } \\
\text { Findings.Queue }\end{array}$ & 2.6392 & 0.16 & 2.2768 & 3.1655 & 0.00 & 19.0000 \\
\hline Attending Visits.Queue & 2.3742 & 0.14 & 2.0201 & 2.8063 & 0.00 & 17.0000 \\
\hline CatScan Process.Queue & 0.00707747 & 0.00 & 0.00635129 & 0.00855236 & 0.00 & 3.0000 \\
\hline Last Visit.Queue & 0.00001925 & 0.00 & 0.00 & 0.00007749 & 0.00 & 4.0000 \\
\hline Nurse Visit Again.Queue & 0.00000945 & 0.00 & 0.00 & 0.00003671 & 0.00 & 2.0000 \\
\hline Nurse Visit.Queue & 0.00000788 & 0.00 & 0.00 & 0.00002530 & 0.00 & 2.0000 \\
\hline PCA Visits.Queue & 0.00018192 & 0.00 & 0.00004614 & 0.00049554 & 0.00 & 4.0000 \\
\hline Procedure Room Process.Queue & 0.00027267 & 0.00 & 0.00015407 & 0.00039770 & 0.00 & 2.0000 \\
\hline Resident Visits.Queue & 0.01352493 & 0.00 & 0.01077678 & 0.01635168 & 0.00 & 6.0000 \\
\hline Seize Exam Room.Queue & 1.1862 & 0.21 & 0.7296 & 1.8681 & 0.00 & 42.0000 \\
\hline Technician Visits.Queue & 0.01445622 & 0.00 & 0.01274368 & 0.01615158 & 0.00 & 4.0000 \\
\hline Triage.Queue & 0.02998601 & 0.00 & 0.02667696 & 0.03188222 & 0.00 & 6.0000 \\
\hline XRay Process.Queue & 0.00765690 & 0.00 & 0.00621853 & 0.00891171 & 0.00 & 4.0000 \\
\hline
\end{tabular}




\section{Kosairs ER Simulation}

Replications: $10 \quad$ Time Units: Minutes

\section{Resource}

\section{Usage}

\begin{tabular}{|c|c|c|c|c|c|c|}
\hline Instantaneous Utilization & Average & Half Width & $\begin{array}{c}\text { Minimum } \\
\text { Average }\end{array}$ & $\begin{array}{c}\text { Maximum } \\
\text { Average }\end{array}$ & $\begin{array}{l}\text { Minimum } \\
\text { Value }\end{array}$ & $\begin{array}{l}\text { Maximum } \\
\text { Value }\end{array}$ \\
\hline Attending & 0.7569 & 0.01 & 0.7377 & 0.7864 & 0.00 & 1.0000 \\
\hline Catscan Machine & 0.1017 & 0.00 & 0.0972 & 0.1046 & 0.00 & 1.0000 \\
\hline Exam Room & 0.5441 & 0.01 & 0.5152 & 0.5854 & 0.00 & 1.0000 \\
\hline Nurse & 0.07277248 & 0.00 & 0.07063978 & 0.07488978 & 0.00 & 1.0000 \\
\hline Patient & 0.00 & 0.00 & 0.00 & 0.00 & 0.00 & 0.00 \\
\hline PCA & 0.05379264 & 0.00 & 0.05086539 & 0.05604741 & 0.00 & 1.0000 \\
\hline ProcedureRoom & 0.05287234 & 0.00 & 0.04925528 & 0.05471368 & 0.00 & 1.0000 \\
\hline Resident & 0.2242 & 0.00 & 0.2191 & 0.2335 & 0.00 & 1.0000 \\
\hline Technician & 0.1303 & 0.00 & 0.1255 & 0.1378 & 0.00 & 1.0000 \\
\hline Triage Nurse & 0.2340 & 0.00 & 0.2295 & 0.2378 & 0.00 & 1.0000 \\
\hline Triage Room & 0.2340 & 0.00 & 0.2295 & 0.2378 & 0.00 & 1.0000 \\
\hline Xray Machine & 0.1009 & 0.00 & 0.0976 & 0.1054 & 0.00 & 1.0000 \\
\hline Number Busy & Average & Half Width & $\begin{array}{c}\text { Minimum } \\
\text { Average }\end{array}$ & $\begin{array}{c}\text { Maximum } \\
\text { Average }\end{array}$ & $\begin{array}{c}\text { Minimum } \\
\text { Value }\end{array}$ & $\begin{array}{l}\text { Maximum } \\
\text { Value }\end{array}$ \\
\hline Attending & 1.4694 & 0.01 & 1.4385 & 1.5066 & 0.00 & 3.0000 \\
\hline Catscan Machine & 0.1017 & 0.00 & 0.0972 & 0.1046 & 0.00 & 1.0000 \\
\hline Exam Room & 16.3240 & 0.37 & 15.4565 & 17.5614 & 0.00 & 30.0000 \\
\hline Nurse & 0.6338 & 0.01 & 0.6250 & 0.6481 & 0.00 & 9.0000 \\
\hline Patient & 0.00 & 0.00 & 0.00 & 0.00 & 0.00 & 0.00 \\
\hline PCA & 0.2125 & 0.00 & 0.2023 & 0.2176 & 0.00 & 5.0000 \\
\hline ProcedureRoom & 0.1057 & 0.00 & 0.0985 & 0.1094 & 0.00 & 2.0000 \\
\hline Resident & 0.7719 & 0.01 & 0.7572 & 0.8008 & 0.00 & 4.0000 \\
\hline Technician & 0.1303 & 0.00 & 0.1255 & 0.1378 & 0.00 & 1.0000 \\
\hline Triage Nurse & 0.4679 & 0.00 & 0.4591 & 0.4756 & 0.00 & 2.0000 \\
\hline Triage Room & 0.4679 & 0.00 & 0.4591 & 0.4756 & 0.00 & 2.0000 \\
\hline Xray Machine & 0.1009 & 0.00 & 0.0976 & 0.1054 & 0.00 & 1.0000 \\
\hline
\end{tabular}




\section{Kosairs ER Simulation}

Replications: 10 Time Units: Minutes

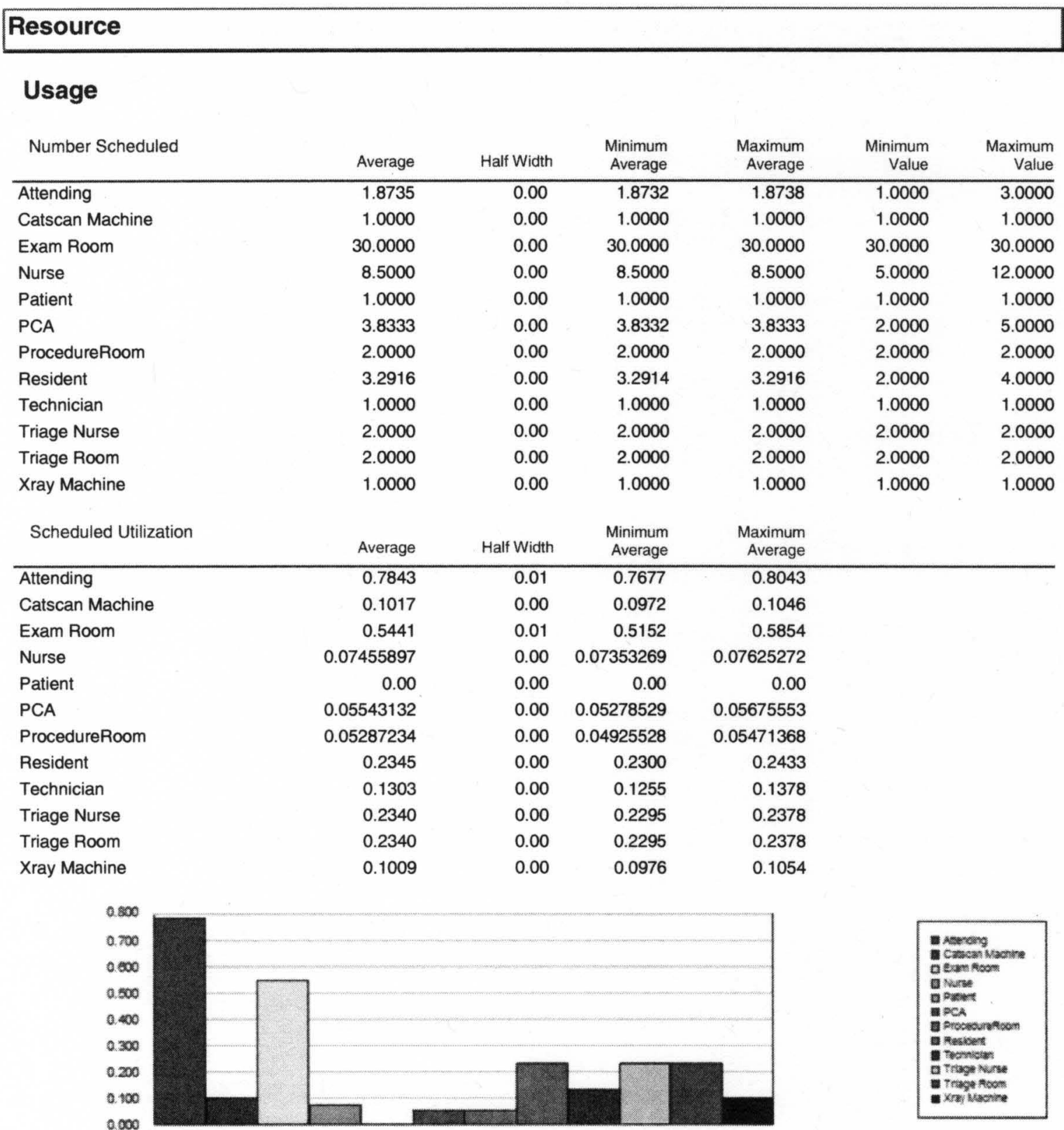


Kosairs ER Simulation

Replications: $10 \quad$ Time Units: Minutes

\section{Resource}

\section{Usage}

\begin{tabular}{lrrrr} 
Total Number Seized & Average & Half Width & $\begin{array}{r}\text { Minimum } \\
\text { Average }\end{array}$ & $\begin{array}{r}\text { Maximum } \\
\text { Average }\end{array}$ \\
\hline Attending & 22672.50 & 209.69 & 22332.00 & 23248.00 \\
Catscan Machine & 1363.70 & 24.17 & 1310.00 & 1400.00 \\
Exam Room & 9255.10 & 67.79 & 9095.00 & 9377.00 \\
Nurse & 31237.30 & 215.04 & 30871.00 & 31754.00 \\
Patient & 0.00 & 0.00 & 0.00 & 0.00 \\
PCA & 6670.10 & 70.53 & 6440.00 & 6792.00 \\
ProcedureRoom & 1418.00 & 31.75 & 1320.00 & 1473.00 \\
Resident & 11887.20 & 153.04 & 11648.00 & 12312.00 \\
Technician & 1879.10 & 36.23 & 1805.00 & 1974.00 \\
Triage Nurse & 9257.00 & 68.59 & 9095.00 & 9377.00 \\
Triage Room & 9257.00 & 68.59 & 9095.00 & 9377.00 \\
Xray Machine & 1353.70 & 27.56 & 1304.00 & 1434.00
\end{tabular}

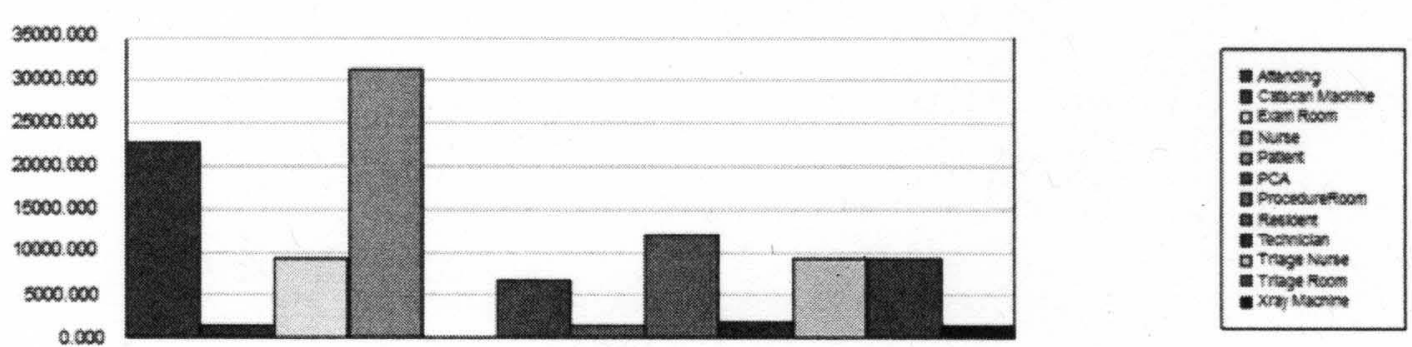


Kosairs ER Simulation

Values Across All Replications

Replications: $10 \quad$ Time Units: Minutes

User Specified

\section{Counter}

\begin{tabular}{lrrrr} 
Count & Average & Half Width & $\begin{array}{r}\text { Minimum } \\
\text { Average }\end{array}$ & $\begin{array}{r}\text { Maximum } \\
\text { Average }\end{array}$ \\
\hline CatScan Count & 1363.60 & 24.13 & 1310.00 & 1400.00 \\
Leaves ER Count & 9255.30 & 67.91 & 9095.00 & 9377.00 \\
Procedure Room Count & 1418.00 & 31.75 & 1320.00 & 1473.00 \\
Stays in Room Count & 39814.60 & 314.79 & 39181.00 & 40658.00 \\
XRay Count & 1353.60 & 27.50 & 1304.00 & 1434.00
\end{tabular}

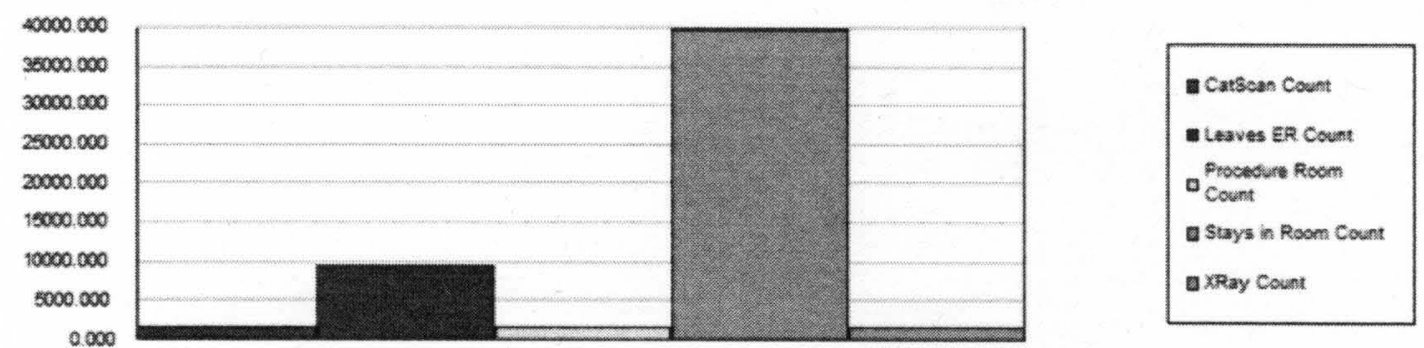


APPENDIX III

ARENA RESULTS FOR TEACH ONLY METHOD 
Kosairs ER Simulation

Replications: $10 \quad$ Time Units: Minutes

Key Performance Indicators

\section{System}

Number Out

Average

9,281 
Kosairs ER Simulation

Replications: 10 Time Units: Minutes

Entity

Time

\begin{tabular}{|c|c|c|c|c|c|c|}
\hline VA Time & Average & Half Width & $\begin{array}{c}\text { Minimum } \\
\text { Average }\end{array}$ & $\begin{array}{c}\text { Maximum } \\
\text { Average }\end{array}$ & $\begin{array}{c}\text { Minimum } \\
\text { Value }\end{array}$ & $\begin{array}{l}\text { Maximum } \\
\text { Value }\end{array}$ \\
\hline Patient 1 & 45.8649 & 0.15 & 45.3911 & 46.1359 & 7.4285 & 386.27 \\
\hline NVA Time & Average & Half Width & $\begin{array}{c}\text { Minimum } \\
\text { Average }\end{array}$ & $\begin{array}{r}\text { Maximum } \\
\text { Average }\end{array}$ & $\begin{array}{c}\text { Minimum } \\
\text { Value }\end{array}$ & $\begin{array}{l}\text { Maximum } \\
\text { Value }\end{array}$ \\
\hline Patient 1 & 0.00 & 0.00 & 0.00 & 0.00 & 0.00 & 0.00 \\
\hline Wait Time & Average & Half Width & $\begin{array}{c}\text { Minimum } \\
\text { Average }\end{array}$ & $\begin{array}{r}\text { Maximum } \\
\text { Average }\end{array}$ & $\begin{array}{c}\text { Minimum } \\
\text { Value }\end{array}$ & $\begin{array}{l}\text { Maximum } \\
\text { Value }\end{array}$ \\
\hline Patient 1 & 222.41 & 5.67 & 206.55 & 230.54 & 10.4484 & 2592.78 \\
\hline Transfer Time & Average & Half Width & $\begin{array}{c}\text { Minimum } \\
\text { Average }\end{array}$ & $\begin{array}{c}\text { Maximum } \\
\text { Average }\end{array}$ & $\begin{array}{c}\text { Minimum } \\
\text { Value }\end{array}$ & $\begin{array}{l}\text { Maximum } \\
\text { Value }\end{array}$ \\
\hline Patient 1 & 2.6655 & 0.01 & 2.6577 & 2.6774 & 2.0000 & 8.5000 \\
\hline Other Time & Average & Half Width & $\begin{array}{c}\text { Minimum } \\
\text { Average }\end{array}$ & $\begin{array}{c}\text { Maximum } \\
\text { Average }\end{array}$ & $\begin{array}{c}\text { Minimum } \\
\text { Value }\end{array}$ & $\begin{array}{l}\text { Maximum } \\
\text { Value }\end{array}$ \\
\hline Patient 1 & 0.00 & 0.00 & 0.00 & 0.00 & 0.00 & 0.00 \\
\hline Total Time & Average & Half Width & $\begin{array}{c}\text { Minimum } \\
\text { Average }\end{array}$ & $\begin{array}{c}\text { Maximum } \\
\text { Average }\end{array}$ & $\begin{array}{c}\text { Minimum } \\
\text { Value }\end{array}$ & $\begin{array}{l}\text { Maximum } \\
\text { Value }\end{array}$ \\
\hline Patient 1 & 270.94 & 5.76 & 254.97 & 279.34 & 30.1870 & 2675.26 \\
\hline \multicolumn{7}{|l|}{ Other } \\
\hline Number In & Average & Half Width & $\begin{array}{c}\text { Minimum } \\
\text { Average }\end{array}$ & $\begin{array}{c}\text { Maximum } \\
\text { Average }\end{array}$ & & \\
\hline Patient 1 & 9276.90 & 69.03 & 9118.00 & 9438.00 & & \\
\hline Number Out & Average & Half Width & $\begin{array}{c}\text { Minimum } \\
\text { Average }\end{array}$ & $\begin{array}{c}\text { Maximum } \\
\text { Average }\end{array}$ & & \\
\hline Patient 1 & 9281.30 & 69.95 & 9116.00 & 9436.00 & & \\
\hline WIP & Average & Half Width & $\begin{array}{c}\text { Minimum } \\
\text { Average }\end{array}$ & $\begin{array}{r}\text { Maximum } \\
\text { Average }\end{array}$ & $\begin{array}{c}\text { Minimum } \\
\text { Value }\end{array}$ & $\begin{array}{l}\text { Maximum } \\
\text { Value }\end{array}$ \\
\hline Patient 1 & 20.0732 & 0.53 & 18.5576 & 20.9948 & 0.00 & 77.0000 \\
\hline
\end{tabular}


Kosairs ER Simulation

Replications: $10 \quad$ Time Units: Minutes

\section{Queue}

Time

\begin{tabular}{lrrrrrr} 
Waiting Time & Average & Half Width & $\begin{array}{r}\text { Minimum } \\
\text { Average }\end{array}$ & $\begin{array}{r}\text { Maximum } \\
\text { Average }\end{array}$ & $\begin{array}{r}\text { Minimum } \\
\text { Value }\end{array}$ & $\begin{array}{r}\text { Maximum } \\
\text { Value }\end{array}$ \\
\hline Attending Visits.Queue & 2.4537 & 0.16 & 2.0249 & 2.8809 & 0.00 & 141.81 \\
CatScan Process.Queue & 0.6907 & 0.06 & 0.5811 & 0.8052 & 0.00 & 32.0881 \\
Last Visit.Queue & 0.00001705 & 0.00 & 0.00 & 0.00010221 & 0.00 & 0.5414 \\
Nurse Visit Again.Queue & 0.00002553 & 0.00 & 0.00 & 0.00010758 & 0.00 & 0.7907 \\
Nurse Visit.Queue & 0.00002935 & 0.00 & 0.00 & 0.00009928 & 0.00 & 0.9158 \\
PCA Visits.Queue & 0.00459646 & 0.00 & 0.00202463 & 0.00778166 & 0.00 & 7.3884 \\
Procedure Room Process.Queue & 0.01976558 & 0.01 & 0.00796516 & 0.04687998 & 0.00 & 10.5531 \\
& & & & & & \\
Resident Visits.Queue & 64.3359 & 2.70 & 56.4865 & 68.8587 & 0.00 & 283.74 \\
Seize Exam Room.Queue & 11.9675 & 1.68 & 8.0760 & 15.2008 & 0.00 & 407.53 \\
Technician Visits.Queve & 1.0239 & 0.07 & 0.8742 & 1.1638 & 0.00 & 42.4349 \\
Triage.Queue & 0.4033 & 0.01 & 0.3669 & 0.4380 & 0.00 & 19.8763 \\
XRay Process.Queue & 0.6501 & 0.05 & 0.5355 & 0.7451 & 0.00 & 26.1925
\end{tabular}

\section{Other}

\begin{tabular}{|c|c|c|c|c|c|c|}
\hline Number Waiting & Average & Half Width & $\begin{array}{c}\text { Minimum } \\
\text { Average }\end{array}$ & $\begin{array}{r}\text { Maximum } \\
\text { Average }\end{array}$ & $\begin{array}{l}\text { Minimum } \\
\text { Value }\end{array}$ & $\begin{array}{c}\text { Maximum } \\
\text { Value }\end{array}$ \\
\hline Attending Visits.Queue & 0.2153 & 0.02 & 0.1761 & 0.2538 & 0.00 & 14.0000 \\
\hline CatScan Process.Queue & 0.00754346 & 0.00 & 0.00622519 & 0.00888005 & 0.00 & 3.0000 \\
\hline Last Visit.Queue & 0.00000127 & 0.00 & 0.00 & 0.00000759 & 0.00 & 1.0000 \\
\hline Nurse Visit Again.Queve & 0.00000264 & 0.00 & 0.00 & 0.00001125 & 0.00 & 2.0000 \\
\hline Nurse Visit.Queue & 0.00000217 & 0.00 & 0.00 & 0.00000731 & 0.00 & 2.0000 \\
\hline PCA Visits.Queue & 0.00024789 & 0.00 & 0.00011020 & 0.00041896 & 0.00 & 4.0000 \\
\hline Procedure Room Process.Queue & 0.00022276 & 0.00 & 0.00008933 & 0.00051116 & 0.00 & 2.0000 \\
\hline Resident Visits.Queue & 6.1800 & 0.31 & 5.3005 & 6.6276 & 0.00 & 27.0000 \\
\hline Seize Exam Room.Queue & 0.8880 & 0.13 & 0.5917 & 1.1200 & 0.00 & 44.0000 \\
\hline Technician Visits.Queue & 0.01565099 & 0.00 & 0.01239292 & 0.01827431 & 0.00 & 5.0000 \\
\hline Triage.Queue & 0.02987556 & 0.00 & 0.02670942 & 0.03258338 & 0.00 & 7.0000 \\
\hline XRay Process.Queue & 0.00708680 & 0.00 & 0.00569782 & 0.00845189 & 0.00 & 3.0000 \\
\hline
\end{tabular}




\section{Kosairs ER Simulation}

Replications: $10 \quad$ Time Units: Minutes

\section{Resource}

\section{Usage}

\begin{tabular}{|c|c|c|c|c|c|c|}
\hline Instantaneous Utilization & Average & Half Width & $\begin{array}{l}\text { Minimum } \\
\text { Average }\end{array}$ & $\begin{array}{l}\text { Maximum } \\
\text { Average }\end{array}$ & $\begin{array}{c}\text { Minimum } \\
\text { Value }\end{array}$ & $\begin{array}{l}\text { Maximum } \\
\text { Value }\end{array}$ \\
\hline Additional Attending Physician & 0.7768 & 0.01 & 0.7515 & 0.7931 & 0.00 & 1.0000 \\
\hline Attending & 0.3777 & 0.00 & 0.3697 & 0.3905 & 0.00 & 1.0000 \\
\hline Catscan Machine & 0.1018 & 0.00 & 0.0987 & 0.1052 & 0.00 & 1.0000 \\
\hline Exam Room & 0.5233 & 0.01 & 0.4857 & 0.5444 & 0.00 & 1.0000 \\
\hline Nurse & 0.07513450 & 0.00 & 0.07285113 & 0.07738615 & 0.00 & 1.0000 \\
\hline Patient & 0.00 & 0.00 & 0.00 & 0.00 & 0.00 & 0.00 \\
\hline PCA & 0.05611219 & 0.00 & 0.05467699 & 0.05745249 & 0.00 & 1.0000 \\
\hline ProcedureRoom & 0.05283800 & 0.00 & 0.05105378 & 0.05602421 & 0.00 & 1.0000 \\
\hline Resident & 0.2382 & 0.00 & 0.2280 & 0.2444 & 0.00 & 0.5000 \\
\hline Technician & 0.1321 & 0.00 & 0.1229 & 0.1377 & 0.00 & 1.0000 \\
\hline Triage Nurse & 0.2346 & 0.00 & 0.2308 & 0.2389 & 0.00 & 1.0000 \\
\hline Triage Room & 0.2346 & 0.00 & 0.2308 & 0.2389 & $0 . \infty 0$ & 1.0000 \\
\hline Xray Machine & 0.1016 & 0.00 & 0.0991 & 0.1062 & 0.00 & 1.0000 \\
\hline Number Busy & Average & Half Width & $\begin{array}{l}\text { Minimum } \\
\text { Average }\end{array}$ & $\begin{array}{c}\text { Maximum } \\
\text { Average }\end{array}$ & $\begin{array}{c}\text { Minimum } \\
\text { Value }\end{array}$ & $\begin{array}{l}\text { Maximum } \\
\text { Value }\end{array}$ \\
\hline Additional Aftending Physician & 0.7768 & 0.01 & 0.7515 & 0.7931 & 0.00 & 1.0000 \\
\hline Attending & 0.7082 & 0.01 & 0.6946 & 0.7303 & 0.00 & 3.0000 \\
\hline Catscan Machine & 0.1018 & 0.00 & 0.0987 & 0.1052 & 0.00 & 1.0000 \\
\hline Exam Room & 15.6998 & 0.39 & 14.5723 & 16.3316 & 0.00 & 30.0000 \\
\hline Nurse & 0.6356 & 0.01 & 0.6218 & 0.6524 & $0 . \infty$ & 9.0000 \\
\hline Patient & 0.00 & 0.00 & 0.00 & 0.00 & 0.00 & 0.00 \\
\hline PCA & 0.2166 & 0.00 & 0.2122 & 0.2211 & 0.00 & 5.0000 \\
\hline ProcedureRoom & 0.1057 & 0.00 & 0.1021 & 0.1120 & 0.00 & 2.0000 \\
\hline Resident & 0.7768 & 0.01 & 0.7515 & 0.7931 & 0.00 & 1.0000 \\
\hline Technician & 0.1321 & 0.00 & 0.1229 & 0.1377 & 0.00 & 1.0000 \\
\hline Triage Nurse & 0.4693 & 0.00 & 0.4615 & 0.4777 & 0.00 & 2.0000 \\
\hline Triage Room & 0.4693 & 0.00 & 0.4615 & 0.4777 & 0.00 & 2.0000 \\
\hline Xray Machine & 0.1016 & 0.00 & 0.0991 & 0.1062 & 0.00 & 1.0000 \\
\hline
\end{tabular}


Kosairs ER Simulation

Replications: $10 \quad$ Time Units: Minutes

Resource

Usage

\begin{tabular}{lrrrrrr} 
Number Scheduled & Average & Half Width & $\begin{array}{r}\text { Minimum } \\
\text { Average }\end{array}$ & $\begin{array}{r}\text { Maximum } \\
\text { Average }\end{array}$ & $\begin{array}{r}\text { Minimum } \\
\text { Value }\end{array}$ & $\begin{array}{r}\text { Maximum } \\
\text { Value }\end{array}$ \\
\hline Additional Attending Physician & 1.0000 & 0.00 & 1.0000 & 1.0000 & 1.0000 & 1.0000 \\
Attending & 1.8745 & 0.00 & 1.8741 & 1.8747 & 1.0000 & 3.0000 \\
Catscan Machine & 1.0000 & 0.00 & 1.0000 & 1.0000 & 1.0000 & 1.0000 \\
Exam Room & 30.0000 & 0.00 & 30.0000 & 30.0000 & 30.0000 & 30.0000 \\
Nurse & 8.5000 & 0.00 & 8.5000 & 8.5000 & 5.0000 & 12.0000 \\
Patient & 1.0000 & 0.00 & 1.0000 & 1.0000 & 1.0000 & 1.0000 \\
PCA & 3.8333 & 0.00 & 3.8333 & 3.8333 & 2.0000 & 5.0000 \\
ProcedureRoom & 2.0000 & 0.00 & 2.0000 & 2.0000 & 2.0000 & 2.0000 \\
Resident & 3.2917 & 0.00 & 3.2917 & 3.2917 & 2.0000 & 4.0000 \\
Technician & 1.0000 & 0.00 & 1.0000 & 1.0000 & 1.0000 & 1.0000 \\
Triage Nurse & 2.0000 & 0.00 & 2.0000 & 2.0000 & 2.0000 & 2.0000 \\
Triage Room & 2.0000 & 0.00 & 2.0000 & 2.0000 & 2.0000 & 2.0000 \\
Xray Machine & 1.0000 & 0.00 & 1.0000 & 1.0000 & 1.0000 & 1.0000
\end{tabular}


Kosairs ER Simulation

Replications: 10 Time Units: Minutes

\section{Resource}

\section{Usage}

\begin{tabular}{|c|c|c|c|c|c|c|}
\hline Scheduled Utilization & Average & Half Width & $\begin{array}{c}\text { Minimum } \\
\text { Average }\end{array}$ & $\begin{array}{r}\text { Maximum } \\
\text { Average }\end{array}$ & & \\
\hline Additional Attending Physician & 0.7768 & 0.01 & 0.7515 & \multicolumn{2}{|l|}{0.7931} & \\
\hline Attending & 0.3778 & 0.00 & 0.3706 & \multicolumn{2}{|l|}{0.3896} & \\
\hline Catscan Machine & 0.1018 & 0.00 & 0.0987 & \multicolumn{2}{|l|}{0.1052} & \\
\hline Exam Room & 0.5233 & 0.01 & 0.4857 & \multicolumn{2}{|l|}{0.5444} & \\
\hline Nurse & 0.07477665 & 0.00 & 0.07314906 & \multicolumn{2}{|l|}{0.07674709} & \\
\hline Patient & 0.00 & 0.00 & 0.00 & \multicolumn{2}{|l|}{0.00} & \\
\hline PCA & 0.05651104 & 0.00 & 0.05534570 & \multicolumn{2}{|l|}{0.05767873} & \\
\hline ProcedureRoom & 0.05283800 & 0.00 & 0.05105378 & \multicolumn{2}{|l|}{0.05602421} & \\
\hline Resident & 0.2360 & 0.00 & 0.2283 & \multicolumn{2}{|l|}{0.2410} & \\
\hline Technician & 0.1321 & 0.00 & 0.1229 & \multicolumn{2}{|l|}{0.1377} & \\
\hline Triage Nurse & 0.2346 & 0.00 & 0.2308 & \multicolumn{2}{|l|}{0.2389} & \\
\hline Triage Room & 0.2346 & 0.00 & 0.2308 & \multicolumn{2}{|l|}{0.2389} & \\
\hline Xray Machine & 0.1016 & 0.00 & 0.0991 & \multicolumn{2}{|l|}{0.1062} & \\
\hline 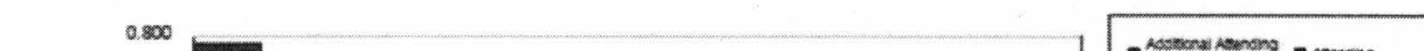 & \multirow{2}{*}{\multicolumn{4}{|c|}{$\begin{array}{l}0.300 \\
0.700\end{array}$}} & \multirow{7}{*}{\multicolumn{2}{|c|}{ 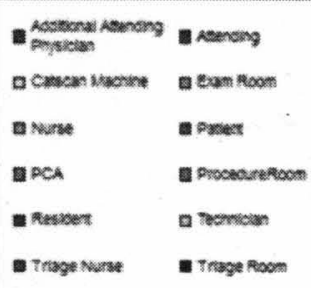 }} \\
\hline 0.000 & & & & & & \\
\hline 0.800 & & & & & & \\
\hline 0.400 & & & & & & \\
\hline 0.300 & & & & & & \\
\hline 0.200 & & & & & & \\
\hline 0.100 & & & & & & \\
\hline
\end{tabular}


Kosairs ER Simulation

Replications: $10 \quad$ Time Units: Minutes

\section{Resource}

Usage

\begin{tabular}{|c|c|c|c|c|c|c|}
\hline Total Number Seized & Average & Half Width & $\begin{array}{c}\text { Minimum } \\
\text { Average }\end{array}$ & $\begin{array}{r}\text { Maximum } \\
\text { Average }\end{array}$ & & \\
\hline Additional Attending Physician & 12024.10 & 120.25 & 11735.00 & 12297.00 & & \\
\hline Attending & 10989.00 & 85.76 & 10805.00 & 11218.00 & & \\
\hline Catscan Machine & 1366.80 & 19.26 & 1330.00 & 1414.00 & & \\
\hline Exam Room & 9277.20 & 69.51 & 9116.00 & 9435.00 & & \\
\hline Nurse & 31383.80 & 300.25 & 30826.00 & 32134.00 & & \\
\hline Patient & 0.00 & 0.00 & 0.00 & 0.00 & & \\
\hline PCA & 6767.40 & 83.76 & 6599.00 & 6980.00 & & \\
\hline ProcedureRoom & 1418.80 & 30.22 & 1366.00 & 1498.00 & & \\
\hline Resident & 12024.10 & 120.25 & 11735.00 & 12297.00 & & \\
\hline Technician & 1911.00 & 49.21 & 1776.00 & 2005.00 & & \\
\hline Triage Nurse & 9277.70 & 68.98 & 9121.00 & 9439.00 & & \\
\hline Triage Room & 9277.70 & 68.98 & 9121.00 & 9439.00 & & \\
\hline Xray Machine & 1363.90 & 24.29 & 1326.00 & 1421.00 & & \\
\hline $\begin{array}{l}30000,000 \\
30000,000\end{array}$ & & & & & 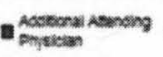 & ID neromg \\
\hline 20000000 & & & & & 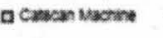 & at zan noon \\
\hline 20000000 & & & & & a Nuse & apoes \\
\hline 15000000 & & & & & apea & a Procenountion \\
\hline 10000,000 & & & & & aneweent & a rancian \\
\hline 5000.000 & & & & & - Trage Nonse & - trage from \\
\hline 0.000 & & & & & a xas Masive & \\
\hline
\end{tabular}


Kosairs ER Simulation

Replications: $10 \quad$ Time Units: Minutes

User Specified

\section{Counter}

\begin{tabular}{lrrrr} 
Count & Average & Half Width & $\begin{array}{r}\text { Minimum } \\
\text { Average }\end{array}$ & $\begin{array}{r}\text { Maximum } \\
\text { Average }\end{array}$ \\
\hline CatScan Count & 1366.80 & 19.26 & 1330.00 & 1414.00 \\
Leaves ER Count & 9281.30 & 69.95 & 9116.00 & 9436.00 \\
Procedure Room Count & 1418.80 & 30.22 & 1366.00 & 1498.00 \\
Stays in Room Count & 40367.80 & 356.16 & 39656.00 & 41144.00 \\
XRay Count & 1364.00 & 24.27 & 1326.00 & 1421.00
\end{tabular}

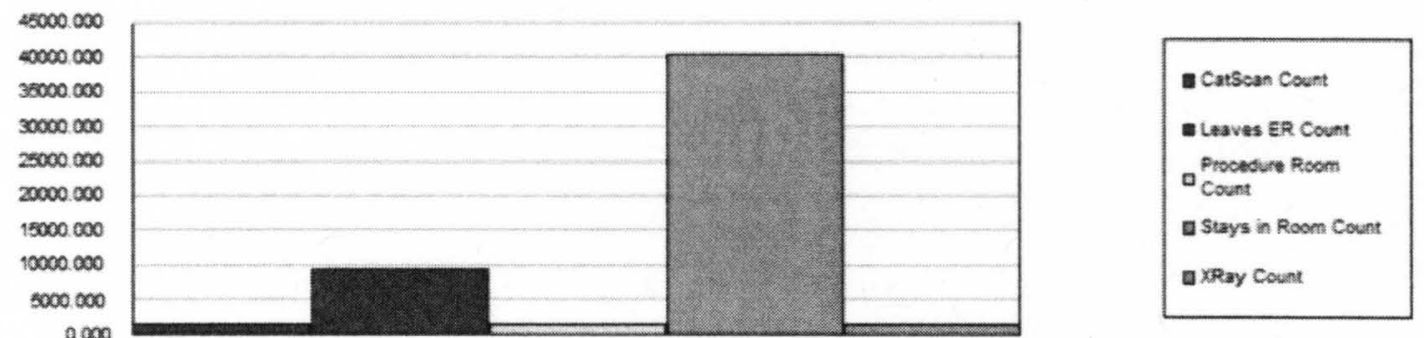




\section{APPENDIX IV}

ARENA RESULTS FOR ATTENDING WITH RESIDENT METHOD 
Kosairs ER Simulation

Replications:

10

Time Units:

Minutes

Key Performance Indicators

System

Number Out
Average

9,305 
Kosairs ER Simulation

Replications: 10 Time Units: Minutes

\section{Entity}

Time

\begin{tabular}{|c|c|c|c|c|c|c|}
\hline VA Time & Average & Half Width & $\begin{array}{c}\text { Minimum } \\
\text { Average }\end{array}$ & $\begin{array}{c}\text { Maximum } \\
\text { Average }\end{array}$ & $\begin{array}{l}\text { Minimum } \\
\text { Value }\end{array}$ & $\begin{array}{l}\text { Maximum } \\
\text { Value }\end{array}$ \\
\hline Patient 1 & 45.7309 & 0.25 & 45.2860 & 46.2834 & 7.1054 & 294.68 \\
\hline NVA Time & Average & Half Width & $\begin{array}{c}\text { Minimum } \\
\text { Average }\end{array}$ & $\begin{array}{c}\text { Maximum } \\
\text { Average }\end{array}$ & $\begin{array}{c}\text { Minimum } \\
\text { Value }\end{array}$ & $\begin{array}{l}\text { Maximum } \\
\text { Value }\end{array}$ \\
\hline Patient 1 & 0.00 & 0.00 & 0.00 & 0.00 & 0.00 & 0.00 \\
\hline Wait Time & Average & Half Width & $\begin{array}{c}\text { Minimum } \\
\text { Average }\end{array}$ & $\begin{array}{c}\text { Maximum } \\
\text { Average }\end{array}$ & $\begin{array}{c}\text { Minimum } \\
\text { Value }\end{array}$ & $\begin{array}{c}\text { Maximum } \\
\text { Value }\end{array}$ \\
\hline Patient 1 & 214.68 & 4.12 & 205.07 & 223.78 & 12.0649 & 2508.40 \\
\hline Transfer Time & Average & Half Width & $\begin{array}{c}\text { Minimum } \\
\text { Average }\end{array}$ & $\begin{array}{c}\text { Maximum } \\
\text { Average }\end{array}$ & $\begin{array}{c}\text { Minimum } \\
\text { Value }\end{array}$ & $\begin{array}{l}\text { Maximum } \\
\text { Value }\end{array}$ \\
\hline Patient 1 & 2.6640 & 0.00 & 2.6529 & 2.6712 & 2.0000 & 8.5000 \\
\hline Other Time & Average & Half Width & $\begin{array}{c}\text { Minimum } \\
\text { Average }\end{array}$ & $\begin{array}{c}\text { Maximum } \\
\text { Average }\end{array}$ & $\begin{array}{c}\text { Minimum } \\
\text { Value }\end{array}$ & $\begin{array}{c}\text { Maximum } \\
\text { Value }\end{array}$ \\
\hline Patient 1 & 0.00 & 0.00 & 0.00 & 0.00 & 0.00 & 0.00 \\
\hline Total Time & Average & Half Width & $\begin{array}{c}\text { Minimum } \\
\text { Average }\end{array}$ & $\begin{array}{c}\text { Maximum } \\
\text { Average }\end{array}$ & $\begin{array}{l}\text { Minimum } \\
\text { Value }\end{array}$ & $\begin{array}{c}\text { Maximum } \\
\text { Value }\end{array}$ \\
\hline Patient 1 & 263.07 & 4.17 & 253.67 & 272.72 & 33.5644 & 2585.96 \\
\hline \multicolumn{7}{|l|}{ Other } \\
\hline Number in & Average & Half Width & $\begin{array}{c}\text { Minimum } \\
\text { Average }\end{array}$ & $\begin{array}{c}\text { Maximum } \\
\text { Average }\end{array}$ & & \\
\hline Patient 1 & 9298.70 & 60.57 & 9193.00 & 9480.00 & & \\
\hline Number Out & Average & Half Width & $\begin{array}{c}\text { Minimum } \\
\text { Average }\end{array}$ & $\begin{array}{c}\text { Maximum } \\
\text { Average }\end{array}$ & & \\
\hline Patient 1 & 9305.10 & 64.56 & 9205.00 & 9504.00 & & \\
\hline WIP & Average & Half Width & $\begin{array}{c}\text { Minimum } \\
\text { Average }\end{array}$ & $\begin{array}{c}\text { Maximum } \\
\text { Average }\end{array}$ & $\begin{array}{c}\text { Minimum } \\
\text { Value }\end{array}$ & $\begin{array}{l}\text { Maximum } \\
\text { Value }\end{array}$ \\
\hline Patient 1 & 19.5301 & 0.37 & 18.7335 & 20.2272 & 0.00 & 75.0000 \\
\hline
\end{tabular}


Kosairs ER Simulation

Replications: 10 Time Units: Minutes

\section{Queue}

\section{Time}

\begin{tabular}{|c|c|c|c|c|c|c|}
\hline Waiting Trme & Average & Half Width & $\begin{array}{c}\text { Minimum } \\
\text { Average }\end{array}$ & $\begin{array}{c}\text { Maximum } \\
\text { Average }\end{array}$ & $\begin{array}{c}\text { Minimum } \\
\text { Value }\end{array}$ & $\begin{array}{r}\text { Maximum } \\
\text { Value }\end{array}$ \\
\hline Attending Visits.Queue & 31.6874 & 1.20 & 28.9566 & 34.1011 & 0.00 & 266.05 \\
\hline CatScan Process.Queue & 0.6496 & 0.02 & 0.6027 & 0.6885 & 0.00 & 26.4459 \\
\hline Last Visit.Queue & 0.00013549 & 0.00 & 0.00 & 0.00041601 & 0.00 & 1.5818 \\
\hline Nurse Visit Again.Queue & 0.00002801 & 0.00 & 0.00 & 0.00011283 & 0.00 & 1.0093 \\
\hline Nurse Visit.Queue & 0.00002303 & 0.00 & 0.00 & 0.00016035 & 0.00 & 1.1597 \\
\hline PCA Visits. Queue & 0.00393476 & 0.00 & 0.00127249 & 0.00623607 & 0.00 & 6.7366 \\
\hline Procedure Room Process.Queue & 0.02308232 & 0.01 & 0.00557266 & 0.03559870 & 0.00 & 10.9154 \\
\hline Seize Exam Room.Queue & 12.7968 & 1.33 & 9.5137 & 16.4650 & 0.00 & 261.61 \\
\hline Technician Visits.Queue & 1.0317 & 0.05 & 0.9567 & 1.1453 & 0.00 & 28.2207 \\
\hline Triage.Queve & 0.4103 & 0.02 & 0.3500 & 0.4567 & 0.00 & 19.3268 \\
\hline XRay Process.Queue & 0.6687 & 0.07 & 0.5477 & 0.8484 & 0.00 & 27.1750 \\
\hline \multicolumn{7}{|l|}{ Other } \\
\hline Number Waiting & Average & Half Width & $\begin{array}{c}\text { Minimum } \\
\text { Average }\end{array}$ & $\begin{array}{c}\text { Maximum } \\
\text { Average }\end{array}$ & $\begin{array}{c}\text { Minimum } \\
\text { Value }\end{array}$ & $\begin{array}{l}\text { Maximum } \\
\text { Value }\end{array}$ \\
\hline Attending Visits.Queue & 5.8058 & 0.25 & 5.2872 & 6.3442 & 0.00 & 29.0000 \\
\hline CatScan Process.Queue & 0.00713174 & 0.00 & 0.00674471 & 0.00755938 & 0.00 & 3.0000 \\
\hline Last Visit.Queue & 0.00001006 & 0.00 & 0.00 & 0.00003089 & 0.00 & 3.0000 \\
\hline Nurse Visit Again.Queue & 0.00000287 & 0.00 & 0.00 & 0.00001152 & 0.00 & 1.0000 \\
\hline Nurse Visit.Queue & 0.00000172 & 0.00 & 0.00 & 0.00001200 & 0.00 & 1.0000 \\
\hline PCA Visits.Queue & 0.00021161 & 0.00 & 0.00007080 & 0.00033022 & 0.00 & 2.0000 \\
\hline Procedure Room Process.Queue & 0.00025849 & 0.00 & 0.00006263 & 0.00040264 & 0.00 & 2.0000 \\
\hline Seize Exam Room.Queue & 0.9493 & 0.10 & 0.7044 & 1.2381 & 0.00 & 35.0000 \\
\hline Technician Visits.Queue & 0.01586972 & 0.00 & 0.01404560 & 0.01846698 & 0.00 & 4.0000 \\
\hline Triage.Queue & 0.03046794 & 0.00 & 0.02584601 & 0.03456996 & 0.00 & 7.0000 \\
\hline XRay Process.Queue & 0.00729906 & 0.00 & 0.00581919 & 0.00971084 & 0.00 & 3.0000 \\
\hline
\end{tabular}


Kosairs ER Simulation

Replications: $10 \quad$ Time Units: Minutes

Resource

Usage

\begin{tabular}{lrrrrrr} 
Instantaneous Utilization & Average & Half Width & $\begin{array}{r}\text { Minimum } \\
\text { Average }\end{array}$ & $\begin{array}{r}\text { Maximum } \\
\text { Average }\end{array}$ & $\begin{array}{r}\text { Minimum } \\
\text { Value }\end{array}$ & $\begin{array}{r}\text { Maximum } \\
\text { Value }\end{array}$ \\
\hline Attending & 0.7640 & 0.01 & 0.7452 & 0.7823 & 0.00 & 1.0000 \\
Catscan Machine & 0.1025 & 0.00 & 0.0980 & 0.1055 & 0.00 & 1.0000 \\
Exam Room & 0.5032 & 0.01 & 0.4836 & 0.5240 & 0.00 & 1.0000 \\
Nurse & 0.07301921 & 0.00 & 0.07200640 & 0.07458016 & 0.00 & 1.0000 \\
Patient & 0.00 & 0.00 & 0.00 & 0.00 & 0.00 & 0.00 \\
PCA & 0.05478615 & 0.00 & 0.05346073 & 0.05602734 & 0.00 & 1.0000 \\
ProcedureRoom & 0.05231864 & 0.00 & 0.05031763 & 0.05434356 & 0.00 & 1.0000 \\
Resident & 0.4290 & 0.00 & 0.4203 & 0.4387 & 0.00 & 1.0000 \\
Technician & 0.1330 & 0.00 & 0.1262 & 0.1391 & 0.00 & 1.0000 \\
Triage Nurse & 0.2350 & 0.00 & 0.2319 & 0.2397 & 0.00 & 1.0000 \\
Triage Room & 0.2350 & 0.00 & 0.2319 & 0.2397 & 0.00 & 1.0000 \\
Xray Machine & 0.1016 & 0.00 & 0.0975 & 0.1070 & 0.00 & 1.0000 \\
& & & & & & \\
Number Busy & & & Minimum & Maximum & Minimum & Maximum \\
& Vavilue & Value \\
\hline Attending & Average & Half Width & Average & Average & Value & 3.0000 \\
Catscan Machine & 1.4837 & 0.01 & 1.4627 & 1.5124 & 0.00 & 1.0000 \\
Exam Room & 0.1025 & 0.00 & 0.0980 & 0.1055 & 0.00 & 30.0000 \\
Nurse & 15.0947 & 0.28 & 14.5085 & 15.7187 & 0.00 & 9.0000 \\
Patient & 0.6369 & 0.00 & 0.6302 & 0.6489 & 0.00 & 0.00 \\
PCA & 0.00 & 0.00 & 0.00 & 0.00 & 0.00 & 5.0000 \\
ProcedureRoom & 0.2155 & 0.00 & 0.2105 & 0.2219 & 0.00 & 2.0000 \\
Resident & 0.1046 & 0.00 & 0.1006 & 0.1087 & 0.00 & 3.0000 \\
Technician & 1.4837 & 0.01 & 1.4627 & 1.5124 & 0.00 & 1.0000 \\
Triage Nurse & 0.1330 & 0.00 & 0.1262 & 0.1391 & 0.00 & 2.0000 \\
Triage Room & 0.4700 & 0.00 & 0.4638 & 0.4795 & 0.00 & 2.0000 \\
Xray Machine & 0.4700 & 0.00 & 0.4638 & 0.4795 & 0.00 & 1.0000
\end{tabular}


Kosairs ER Simulation

Replications: $10 \quad$ Time Units: Minutes

\begin{tabular}{|c|c|c|c|c|c|c|}
\hline \multicolumn{7}{|l|}{ Resource } \\
\hline \multicolumn{7}{|l|}{ Usage } \\
\hline Number Scheduled & Average & Half Width & $\begin{array}{c}\text { Minimum } \\
\text { Average }\end{array}$ & $\begin{array}{r}\text { Maximum } \\
\text { Average }\end{array}$ & $\begin{array}{c}\text { Minimum } \\
\text { Value }\end{array}$ & $\begin{array}{c}\text { Maximum } \\
\text { Value }\end{array}$ \\
\hline Attending & 1.8737 & 0.00 & 1.8735 & 1.8738 & 1.0000 & 3.0000 \\
\hline Catscan Machine & 1.0000 & 0.00 & 1.0000 & 1.0000 & 1.0000 & 1.0000 \\
\hline Exam Room & 30.0000 & 0.00 & 30.0000 & 30.0000 & 30.0000 & 30.0000 \\
\hline Nurse & 8.5000 & 0.00 & 8.5000 & 8.5000 & 5.0000 & 12.0000 \\
\hline Patient & 1.0000 & 0.00 & 1.0000 & 1.0000 & 1.0000 & 1.0000 \\
\hline PCA & 3.8333 & 0.00 & 3.8333 & 3.8333 & 2.0000 & 5.0000 \\
\hline ProcedureRoom & 2.0000 & 0.00 & 2.0000 & 2.0000 & 2.0000 & 2.0000 \\
\hline Resident & 3.2913 & 0.00 & 3.2908 & 3.2915 & 2.0000 & 4.0000 \\
\hline Technician & 1.0000 & 0.00 & 1.0000 & 1.0000 & 1.0000 & 1.0000 \\
\hline Triage Nurse & 2.0000 & 0.00 & 2.0000 & 2.0000 & 2.0000 & 2.0000 \\
\hline Triage Room & 2.0000 & 0.00 & 2.0000 & 2.0000 & 2.0000 & 2.0000 \\
\hline Xray Machine & 1.0000 & 0.00 & 1.0000 & 1.0000 & 1.0000 & 1.0000 \\
\hline Scheduled Utilization & Average & Half Width & $\begin{array}{c}\text { Minimum } \\
\text { Average }\end{array}$ & $\begin{array}{c}\text { Maximum } \\
\text { Average }\end{array}$ & & \\
\hline Attending & 0.7919 & 0.01 & 0.7807 & 0.8072 & & \\
\hline Catscan Machine & 0.1025 & 0.00 & 0.0980 & 0.1055 & & \\
\hline Exam Room & 0.5032 & 0.01 & 0.4836 & 0.5240 & & \\
\hline Nurse & 0.07492825 & 0.00 & 0.07414034 & 0.07633976 & & \\
\hline Patient & 0.00 & 0.00 & 0.00 & 0.00 & & \\
\hline PCA & 0.05622607 & 0.00 & 0.05490377 & 0.05789114 & & \\
\hline ProcedureRoom & 0.05231864 & 0.00 & 0.05031763 & 0.05434356 & & \\
\hline Resident & 0.4508 & 0.00 & 0.4445 & 0.4595 & & \\
\hline Technician & 0.1330 & 0.00 & 0.1262 & 0.1391 & & \\
\hline Triage Nurse & 0.2350 & 0.00 & 0.2319 & 0.2397 & & \\
\hline Triage Room & 0.2350 & 0.00 & 0.2319 & 0.2397 & & \\
\hline Xray Machine & 0.1016 & 0.00 & 0.0975 & 0.1070 & & \\
\hline 0.800 & & & & & & \\
\hline 0.700 & & & & & & 9 \\
\hline 0.000 & & & & & & noom \\
\hline 0.500 & & & & & & \\
\hline 0.400 & & & & & & ourentoom \\
\hline 0.300 & & & & & & ent \\
\hline 0.200 & & & & & & e Nurse \\
\hline 0.100 & & & & & & \\
\hline
\end{tabular}


Kosairs ER Simulation

Replications: $10 \quad$ Time Units: Minutes

\section{Resource}

Usage

\begin{tabular}{lrrrr} 
Total Number Seized & Average & Half Width & $\begin{array}{r}\text { Minimum } \\
\text { Average }\end{array}$ & $\begin{array}{r}\text { Maximum } \\
\text { Average }\end{array}$ \\
\hline Attending & 22942.60 & 151.64 & 22641.00 & 23315.00 \\
Catscan Machine & 1375.60 & 25.68 & 1321.00 & 1416.00 \\
Exam Room & 9304.90 & 64.26 & 9201.00 & 9501.00 \\
Nurse & 31436.80 & 152.29 & 31092.00 & 31854.00 \\
Patient & 0.00 & 0.00 & 0.00 & 0.00 \\
PCA & 6759.70 & 83.28 & 6634.00 & 6970.00 \\
ProcedureRoom & 1402.30 & 22.64 & 1351.00 & 1443.00 \\
Resident & 22942.60 & 151.64 & 22641.00 & 23315.00 \\
Technician & 1924.90 & 39.17 & 1838.00 & 2020.00 \\
Triage Nurse & 9299.90 & 60.68 & 9194.00 & 9483.00 \\
Triage Room & 9299.90 & 60.68 & 9194.00 & 9483.00 \\
Xray Machine & 1363.50 & 25.00 & 1317.00 & 1434.00
\end{tabular}

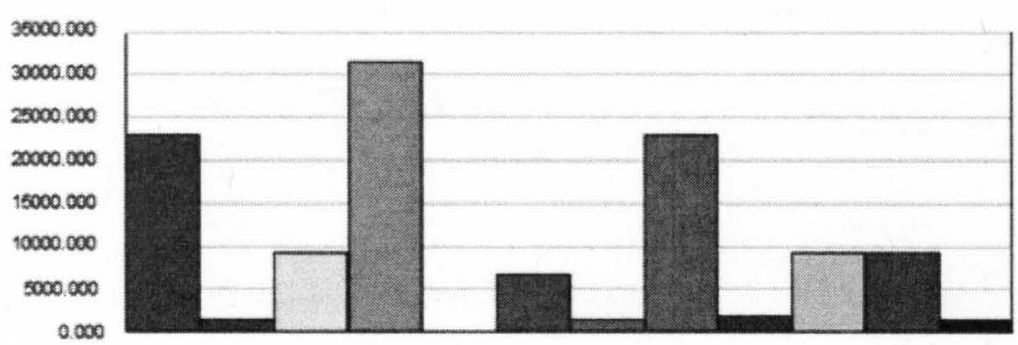


Kosairs ER Simulation

Replications: $10 \quad$ Time Units: Minutes

\section{User Specified}

\section{Counter}

\begin{tabular}{lrrrr} 
Count & Average & Half Width & $\begin{array}{r}\text { Minimum } \\
\text { Average }\end{array}$ & $\begin{array}{r}\text { Maximum } \\
\text { Average }\end{array}$ \\
\hline CatScan Count & 1375.60 & 25.76 & 1321.00 & 1416.00 \\
Leaves ER Count & 9305.10 & 64.56 & 9205.00 & 9504.00 \\
Procedure Room Count & 1402.30 & 22.64 & 1351.00 & 1443.00 \\
Stays in Room Count & 40312.90 & 272.22 & 39829.00 & 41020.00 \\
XRay Count & 1363.60 & 24.90 & 1318.00 & 1434.00
\end{tabular}

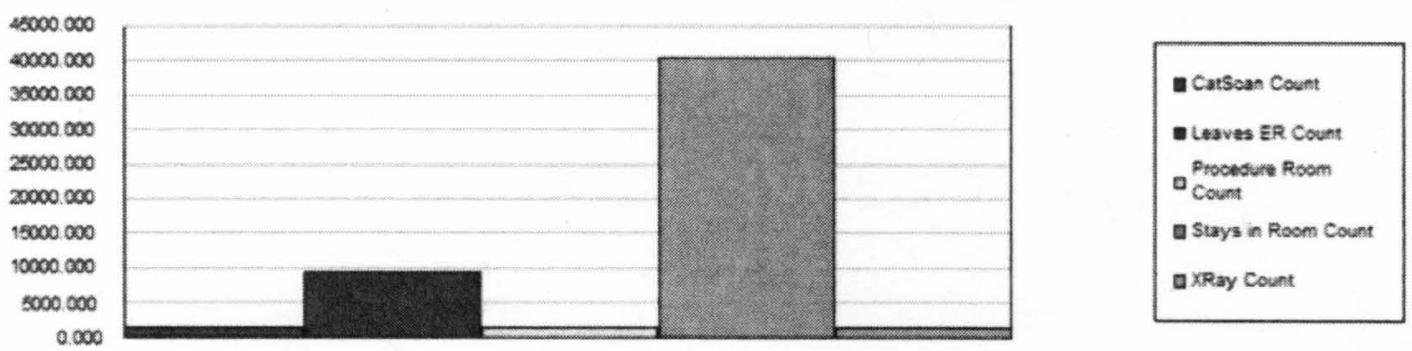


APPENDIX V

ARENA RESULTS OF CURRENT WITH ADJUSTED ATTENDING SCHEDULE 
Kosairs ER Simulation

Replications:

10

Time Units:

Minutes

Key Performance Indicators

System

Number Out
Average

9,248 
Kosairs ER Simulation

Replications: 10 Time Units: Minutes

\section{Entity}

Time

\begin{tabular}{|c|c|c|c|c|c|c|}
\hline VA Time & Average & Half Width & $\begin{array}{c}\text { Minimum } \\
\text { Average }\end{array}$ & $\begin{array}{c}\text { Maximum } \\
\text { Average }\end{array}$ & $\begin{array}{c}\text { Minimum } \\
\text { Value }\end{array}$ & $\begin{array}{c}\text { Maximum } \\
\text { Value }\end{array}$ \\
\hline Patient 1 & 56.5719 & 0.24 & 55.9910 & 57.0269 & 7.8613 & 426.65 \\
\hline NVA Time & Average & Half Width & $\begin{array}{c}\text { Minimum } \\
\text { Average }\end{array}$ & $\begin{array}{c}\text { Maximum } \\
\text { Average }\end{array}$ & $\begin{array}{c}\text { Minimum } \\
\text { Value }\end{array}$ & $\begin{array}{r}\text { Maximum } \\
\text { Value }\end{array}$ \\
\hline Patient 1 & 0.00 & 0.00 & 0.00 & 0.00 & 0.00 & 0.00 \\
\hline Wait Time & Average & Half Width & $\begin{array}{c}\text { Minimum } \\
\text { Average }\end{array}$ & $\begin{array}{c}\text { Maximum } \\
\text { Average }\end{array}$ & $\begin{array}{c}\text { Minimum } \\
\text { Value }\end{array}$ & $\begin{array}{c}\text { Maximum } \\
\text { Value }\end{array}$ \\
\hline Patient 1 & 167.50 & 2.07 & 162.99 & 172.01 & 10.7888 & 4276.30 \\
\hline Transfer Time & Average & Half Width & $\begin{array}{c}\text { Minimum } \\
\text { Average }\end{array}$ & $\begin{array}{c}\text { Maximum } \\
\text { Average }\end{array}$ & $\begin{array}{c}\text { Minimum } \\
\text { Value }\end{array}$ & $\begin{array}{l}\text { Maximum } \\
\text { Value }\end{array}$ \\
\hline Patient 1 & 2.6595 & 0.01 & 2.6405 & 2.6729 & 2.0000 & 6.5000 \\
\hline Other Time & Average & Half Width & $\begin{array}{c}\text { Minimum } \\
\text { Average }\end{array}$ & $\begin{array}{c}\text { Maximum } \\
\text { Average }\end{array}$ & $\begin{array}{c}\text { Minimum } \\
\text { Value }\end{array}$ & $\begin{array}{c}\text { Maximum } \\
\text { Value }\end{array}$ \\
\hline Patient 1 & 0.00 & 0.00 & 0.00 & 0.00 & 0.00 & 0.00 \\
\hline Total Time & Average & Hall Width & $\begin{array}{c}\text { Minimum } \\
\text { Average }\end{array}$ & $\begin{array}{r}\text { Maximum } \\
\text { Average }\end{array}$ & $\begin{array}{c}\text { Minimum } \\
\text { Value }\end{array}$ & $\begin{array}{l}\text { Maximum } \\
\text { Value }\end{array}$ \\
\hline Patient 1 & 226.74 & 2.19 & 221.89 & 231.31 & 30.6188 & 4389.18 \\
\hline
\end{tabular}

\section{Other}

\begin{tabular}{lcccccr} 
Number In & Average & Half Width & $\begin{array}{c}\text { Minimum } \\
\text { Average }\end{array}$ & $\begin{array}{c}\text { Maximum } \\
\text { Average }\end{array}$ \\
\hline Patient 1 & 9247.60 & 78.86 & 9065.00 & 9423.00 \\
Number Out & Average & Hall Width & $\begin{array}{c}\text { Minimum } \\
\text { Average }\end{array}$ & $\begin{array}{r}\text { Maximum } \\
\text { Average }\end{array}$ \\
\hline Patient 1 & 9248.40 & 81.22 & 9060.00 & 9440.00 & & \\
WIP & Average & Half Width & $\begin{array}{c}\text { Minimum } \\
\text { Average }\end{array}$ & $\begin{array}{r}\text { Maximum } \\
\text { Average }\end{array}$ & $\begin{array}{r}\text { Minimum } \\
\text { Value }\end{array}$ & $\begin{array}{r}\text { Maximum } \\
\text { Value }\end{array}$ \\
\hline Patient 1 & 16.7388 & 0.26 & 16.2491 & 17.4014 & 0.00 & 54.0000
\end{tabular}


Kosairs ER Simulation

Replications: 10 Time Units: Minutes

\section{Queue}

\section{Time}

\begin{tabular}{lrrrrrr} 
Waiting Time & Average & Half Width & $\begin{array}{r}\text { Minimum } \\
\text { Average }\end{array}$ & $\begin{array}{r}\text { Maximum } \\
\text { Average }\end{array}$ & $\begin{array}{r}\text { Minimum } \\
\text { Value }\end{array}$ & $\begin{array}{r}\text { Maximum } \\
\text { Value }\end{array}$ \\
\hline Attending Checks Resident & 9.4231 & 0.63 & 8.1768 & 11.1869 & 0.00 & 140.23 \\
Findings.Queue & & & & & & \\
Attending Visits. Queue & 9.3629 & 0.66 & 8.0892 & 11.0281 & 0.00 & 131.03 \\
CatScan Process.Queue & 0.6815 & 0.04 & 0.6188 & 0.7613 & 0.00 & 29.8019 \\
Last Visit.Queue & 0.00000571 & 0.00 & 0.00 & 0.00003479 & 0.00 & 0.3189 \\
Nurse Visit Again.Queue & 0.00000388 & 0.00 & 0.00 & 0.00003879 & 0.00 & 0.5020 \\
Nurse Visit.Queue & 0.00 & 0.00 & 0.00 & 0.00 & 0.00 & 0.00 \\
PCA Visits.Queue & 0.00137962 & 0.00 & 0.00049882 & 0.00253719 & 0.00 & 6.6693 \\
Procedure Room Process.Queue & 0.02635137 & 0.01 & 0.00704408 & 0.04633458 & 0.00 & 8.5467 \\
& & & & & 0.00 & \\
Resident Visits.Queue & 0.1677 & 0.02 & 0.1258 & 0.2026 & 0.00 & 29.6059 \\
Seize Exam Room.Queue & 1.6213 & 0.29 & 1.2100 & 2.5489 & 0.00 & 129.65 \\
Technician Visits.Queue & 1.1329 & 0.06 & 0.9853 & 1.2703 & 0.00 & 38.3797 \\
Triage.Queue & 0.4045 & 0.01 & 0.3795 & 0.4343 & 0.00 & 20.8140 \\
XRay Process.Queue & 0.7158 & 0.06 & 0.6030 & 0.8336 & 0.00 & 39.2260
\end{tabular}

Other

\begin{tabular}{lrrrrrr} 
Number Waiting & Average & Half Width & $\begin{array}{r}\text { Minimum } \\
\text { Average }\end{array}$ & $\begin{array}{r}\text { Maximum } \\
\text { Average }\end{array}$ & $\begin{array}{r}\text { Minimum } \\
\text { Value }\end{array}$ & $\begin{array}{r}\text { Maximum } \\
\text { Value }\end{array}$ \\
\hline Attending Checks Resident & 0.9093 & 0.07 & 0.7913 & 1.0921 & 0.00 & 16.0000 \\
Findings.Queue & & & & & & \\
Attending Visits.Queue & 0.8201 & 0.07 & 0.6949 & 0.9983 & 0.00 & 17.0000 \\
CatScan Process.Queue & 0.00738646 & 0.00 & 0.00639896 & 0.00855596 & 0.00 & 4.0000 \\
Last Visit.Queue & 0.00000042 & 0.00 & 0.00 & 0.00000255 & 0.00 & 1.0000 \\
Nurse Visit Again.Queue & 0.00000040 & 0.00 & 0.00 & 0.00000401 & 0.00 & 1.0000 \\
Nurse Visit.Queue & 0.00 & 0.00 & 0.00 & 0.00 & 0.00 & 0.00 \\
PCA Visits.Queue & 0.00007419 & 0.00 & 0.00002728 & 0.00013753 & 0.00 & 2.0000 \\
Procedure Room Process.Queue & 0.00029782 & 0.00 & 0.00007731 & 0.00050188 & 0.00 & 2.0000 \\
& & & & & 0.00 & \\
Resident Visits.Queue & 0.01618692 & 0.00 & 0.01188969 & 0.01992283 & 0.00 & 7.0000 \\
Seize Exam Room.Queue & 0.1199 & 0.02 & 0.08856824 & 0.1911 & 0.00 & 18.0000 \\
Technician Visits.Queue & 0.01737527 & 0.00 & 0.01479352 & 0.01964048 & 0.00 & 4.0000 \\
Triage.Queue & 0.02984401 & 0.00 & 0.02814792 & 0.03166935 & 0.00 & 6.0000 \\
XRay Process.Queue & 0.00765076 & 0.00 & 0.00621859 & 0.00869693 & 0.00 & 4.0000
\end{tabular}




\section{Kosairs ER Simulation}

Replications: $10 \quad$ Time Units: Minutes

\section{Resource}

\section{Usage}

\begin{tabular}{lrrrrrr} 
Instantaneous Utilization & Average & Half Width & $\begin{array}{r}\text { Minimum } \\
\text { Average }\end{array}$ & $\begin{array}{r}\text { Maximum } \\
\text { Average }\end{array}$ & $\begin{array}{r}\text { Minimum } \\
\text { Value }\end{array}$ & $\begin{array}{r}\text { Maximum } \\
\text { Value }\end{array}$ \\
\hline Attending & 0.6455 & 0.01 & 0.6320 & 0.6718 & 0.00 & 1.0000 \\
Catscan Machine & 0.1009 & 0.00 & 0.0960 & 0.1072 & 0.00 & 1.0000 \\
Exam Room & 0.4389 & 0.01 & 0.4262 & 0.4590 & 0.00 & 1.0000 \\
Nurse & 0.07120155 & 0.00 & 0.06937674 & 0.07294503 & 0.00 & 1.0000 \\
Patient & 0.00 & 0.00 & 0.00 & 0.00 & 0.00 & 0.00 \\
PCA & 0.05338837 & 0.00 & 0.05117285 & 0.05557399 & 0.00 & 1.0000 \\
ProcedureRoom & 0.05266095 & 0.00 & 0.05042512 & 0.05464256 & 0.00 & 1.0000 \\
Resident & 0.2259 & 0.00 & 0.2191 & 0.2311 & 0.00 & 1.0000 \\
Technician & 0.1330 & 0.00 & 0.1262 & 0.1386 & 0.00 & 1.0000 \\
Triage Nurse & 0.2335 & 0.00 & 0.2294 & 0.2369 & 0.00 & 1.0000 \\
Triage Room & 0.2335 & 0.00 & 0.2294 & 0.2369 & 0.00 & 1.0000 \\
Xray Machine & 0.0998 & 0.00 & 0.0960 & 0.1048 & 0.00 & 1.0000 \\
& & & & & & \\
Number Busy & & & Minimum & Maximum & Minimum & Maximum \\
& Average & Half Width & Average & Average & Value & Value \\
\hline Attending & 1.4902 & 0.02 & 1.4655 & 1.5313 & 0.00 & 3.0000 \\
Catscan Machine & 0.1009 & 0.00 & 0.0960 & 0.1072 & 0.00 & 1.0000 \\
Exam Room & 13.1657 & 0.23 & 12.7870 & 13.7702 & 0.00 & 30.0000 \\
Nurse & 0.6354 & 0.01 & 0.6221 & 0.6489 & 0.00 & 9.0000 \\
Patient & 0.00 & 0.00 & 0.00 & 0.00 & 0.00 & 0.00 \\
PCA & 0.2146 & 0.00 & 0.2079 & 0.2218 & 0.00 & 5.0000 \\
ProcedureRoom & 0.1053 & 0.00 & 0.1009 & 0.1093 & 0.00 & 2.0000 \\
Resident & 0.7815 & 0.01 & 0.7606 & 0.8014 & 0.00 & 4.0000 \\
Technician & 0.1330 & 0.00 & 0.1262 & 0.1386 & 0.00 & 1.0000 \\
Triage Nurse & 0.4669 & 0.00 & 0.4587 & 0.4739 & 0.00 & 2.0000 \\
Triage Room & 0.4669 & 0.00 & 0.4587 & 0.4739 & 0.00 & 2.0000 \\
Xray Machine & 0.0998 & 0.00 & 0.0960 & 0.1048 & 0.00 & 1.0000
\end{tabular}




\section{Kosairs ER Simulation}

Replications: $10 \quad$ Time Units: Minutes

\section{Resource}

\section{Usage}

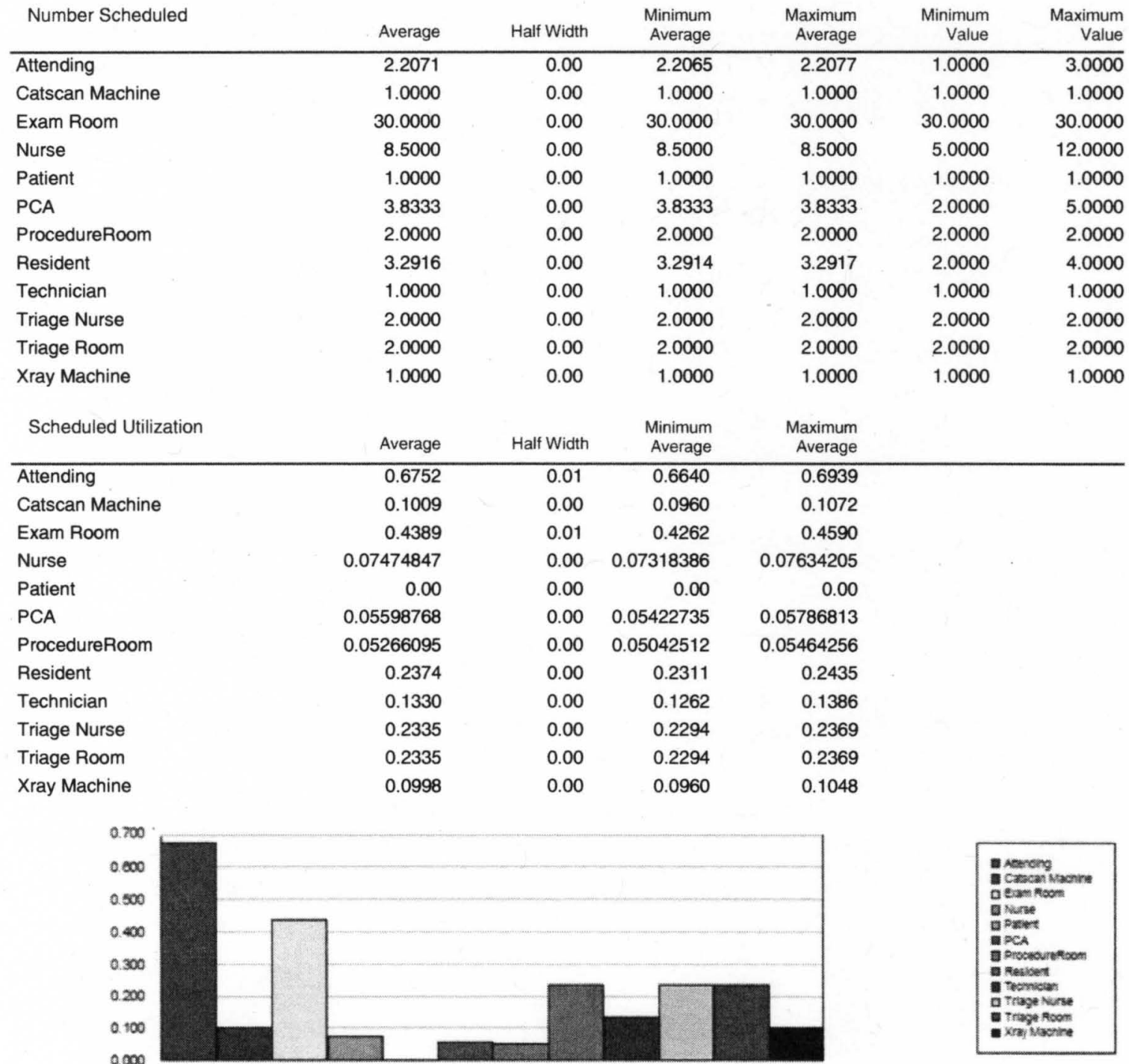

Model Filename: F:IThesis IFinal modelsWew Staff SchedulelERSimulation Final Model with staff 
Kosairs ER Simulation

Replications: 10 Time Units: Minutes

Resource

Usage

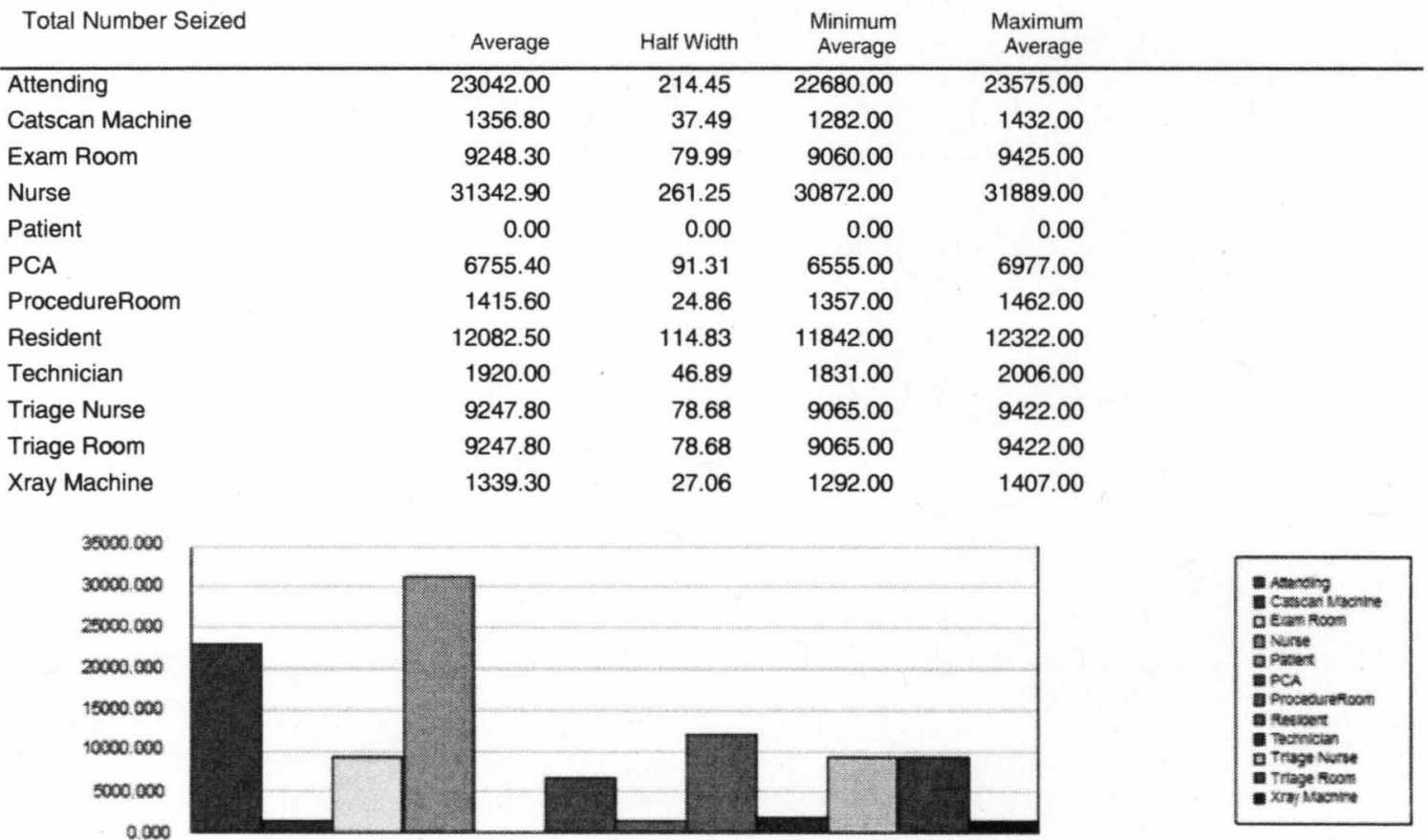

Model Filename: F:IThesis\Final modelsWNew Staff SchedulelERSimulation Final Model with staff 


\section{Kosairs ER Simulation}

Replications: 10 Time Units: Minutes

User Specified

\section{Counter}

\begin{tabular}{lrrrr} 
Count & Average & Half Width & $\begin{array}{r}\text { Minimum } \\
\text { Average }\end{array}$ & $\begin{array}{r}\text { Maximum } \\
\text { Average }\end{array}$ \\
\hline CatScan Count & 1356.80 & 37.49 & 1282.00 & 1432.00 \\
Leaves ER Count & 9248.40 & 81.22 & 9060.00 & 9440.00 \\
Procedure Room Count & 1415.60 & 24.86 & 1357.00 & 1462.00 \\
Stays in Room Count & 40453.10 & 389.38 & 39850.00 & 41232.00 \\
XRay Count & 1339.30 & 27.06 & 1292.00 & 1407.00
\end{tabular}

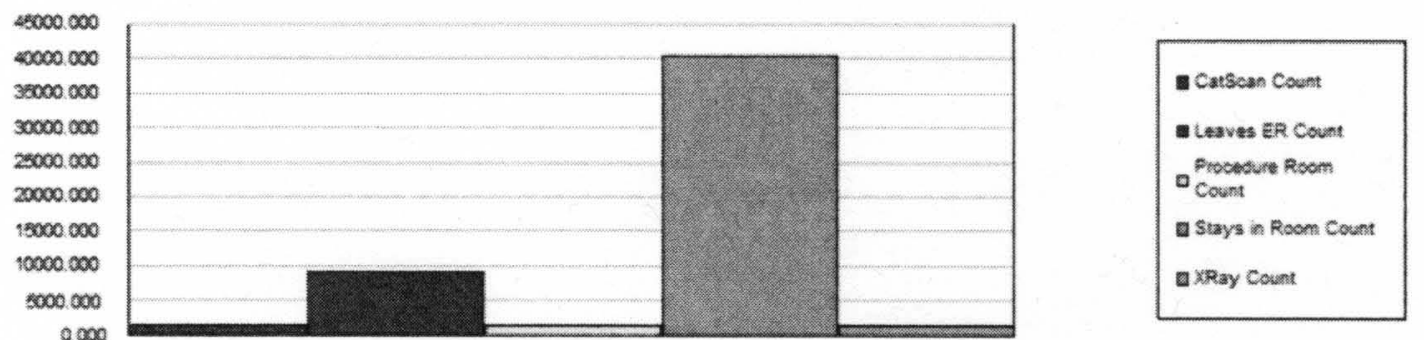


APPENDIX VI

ARENA RESULTS OF TEACH ONLY METHOD WITH STAFF CHANGES 
Values Across All Replications

Kosairs ER Simulation

Replications: 10 Time Units: Minutes

Key Performance Indicators

System

Number Out
Average

9,228 
Kosairs ER Simulation

Replications: 10 Time Units: Minutes

Entity

Time

\begin{tabular}{|c|c|c|c|c|c|c|}
\hline VA Time & Average & Half Width & $\begin{array}{c}\text { Minimum } \\
\text { Average }\end{array}$ & $\begin{array}{r}\text { Maximum } \\
\text { Average }\end{array}$ & $\begin{array}{l}\text { Minimum } \\
\text { Value }\end{array}$ & $\begin{array}{l}\text { Maximum } \\
\text { Value }\end{array}$ \\
\hline Patient 1 & 45.9626 & 0.17 & 45.7253 & 46.5984 & 7.3039 & $\overline{272.44}$ \\
\hline NVA Time & Average & Half Width & $\begin{array}{c}\text { Minimum } \\
\text { Average }\end{array}$ & $\begin{array}{c}\text { Maximum } \\
\text { Average }\end{array}$ & $\begin{array}{l}\text { Minimum } \\
\text { Value }\end{array}$ & $\begin{array}{l}\text { Maximum } \\
\text { Value }\end{array}$ \\
\hline Patient 1 & 0.00 & 0.00 & 0.00 & 0.00 & 0.00 & 0.00 \\
\hline Wait Time & Average & Half Width & $\begin{array}{c}\text { Minimum } \\
\text { Average }\end{array}$ & $\begin{array}{c}\text { Maximum } \\
\text { Average }\end{array}$ & $\begin{array}{c}\text { Minimum } \\
\text { Value }\end{array}$ & $\begin{array}{c}\text { Maximum } \\
\text { Value }\end{array}$ \\
\hline Patient 1 & 219.52 & 4.22 & 210.83 & 229.07 & 8.7076 & 1966.62 \\
\hline Transfer Time & Average & Half Width & $\begin{array}{c}\text { Minimum } \\
\text { Average }\end{array}$ & $\begin{array}{c}\text { Maximum } \\
\text { Average }\end{array}$ & $\begin{array}{c}\text { Minimum } \\
\text { Value }\end{array}$ & $\begin{array}{c}\text { Maximum } \\
\text { Value }\end{array}$ \\
\hline Patient 1 & 2.6646 & 0.00 & 2.6552 & 2.6756 & 2.0000 & 8.0000 \\
\hline Other Time & Average & Half Width & $\begin{array}{c}\text { Minimum } \\
\text { Average }\end{array}$ & $\begin{array}{c}\text { Maximum } \\
\text { Average }\end{array}$ & $\begin{array}{c}\text { Minimum } \\
\text { Value }\end{array}$ & $\begin{array}{c}\text { Maximum } \\
\text { Value }\end{array}$ \\
\hline Patient 1 & 0.00 & 0.00 & 0.00 & 0.00 & 0.00 & 0.00 \\
\hline Total Time & Average & Half Width & $\begin{array}{c}\text { Minimum } \\
\text { Average }\end{array}$ & $\begin{array}{c}\text { Maximum } \\
\text { Average }\end{array}$ & $\begin{array}{c}\text { Minimum } \\
\text { Value }\end{array}$ & $\begin{array}{c}\text { Maximum } \\
\text { Value }\end{array}$ \\
\hline Patient 1 & 268.15 & 4.26 & 259.25 & 277.70 & 32.3556 & 2089.82 \\
\hline
\end{tabular}

Other

\begin{tabular}{|c|c|c|c|c|c|c|}
\hline Number in & Average & Half Width & $\begin{array}{c}\text { Minimum } \\
\text { Average }\end{array}$ & $\begin{array}{c}\text { Maximum } \\
\text { Average }\end{array}$ & & \\
\hline Patient 1 & 9235.20 & 38.27 & 9163.00 & 9315.00 & & \\
\hline Number Out & Average & Half Width & $\begin{array}{c}\text { Minimum } \\
\text { Average }\end{array}$ & $\begin{array}{c}\text { Maximum } \\
\text { Average }\end{array}$ & & \\
\hline Patient 1 & 9227.50 & 40.89 & 9146.00 & 9320.00 & & \\
\hline WIP & Average & Half Width & $\begin{array}{c}\text { Minimum } \\
\text { Average }\end{array}$ & $\begin{array}{r}\text { Maximum } \\
\text { Average }\end{array}$ & $\begin{array}{c}\text { Minimum } \\
\text { Value }\end{array}$ & $\begin{array}{l}\text { Maximum } \\
\text { Value }\end{array}$ \\
\hline Patient 1 & 19.7757 & 0.33 & 19.0155 & 20.6124 & 0.00 & 67.0000 \\
\hline
\end{tabular}




\section{Kosairs ER Simulation}

Replications: 10 Time Units: Minutes

\section{Queue}

\section{Time}

\begin{tabular}{|c|c|c|c|c|c|c|}
\hline Waiting Time & Average & Half Width & $\begin{array}{c}\text { Minimum } \\
\text { Average }\end{array}$ & $\begin{array}{c}\text { Maximum } \\
\text { Average }\end{array}$ & $\begin{array}{c}\text { Minimum } \\
\text { Value }\end{array}$ & $\begin{array}{r}\text { Maximum } \\
\text { Value }\end{array}$ \\
\hline Attending Visits.Queue & 1.3593 & 0.13 & 1.1684 & 1.7763 & 0.00 & 137.17 \\
\hline CatScan Process.Queue & 0.6790 & 0.08 & 0.5144 & 0.8365 & 0.00 & 25.0359 \\
\hline Last Visit.Queue & 0.00007480 & 0.00 & 0.00 & 0.00030846 & 0.00 & 1.3328 \\
\hline Nurse Visit Again.Queue & 0.00003118 & 0.00 & 0.00 & 0.00012930 & 0.00 & 1.6288 \\
\hline Nurse Visit.Queue & 0.00000226 & 0.00 & 0.00 & 0.00002189 & 0.00 & 0.1761 \\
\hline PCA Visits.Queue & 0.00469053 & 0.00 & 0.00240873 & 0.00687196 & 0.00 & 7.6731 \\
\hline Procedure Room Process.Queue & 0.02247312 & 0.01 & 0.00861242 & 0.03233452 & 0.00 & 10.5564 \\
\hline Resident Visits.Queue & 64.6702 & 1.69 & 61.5155 & 68.0701 & 0.00 & 288.78 \\
\hline Seize Exam Room.Queue & 10.2796 & 1.64 & 8.1838 & 15.5103 & 0.00 & 477.37 \\
\hline Technician Visits.Queue & 0.9519 & 0.04 & 0.8745 & 1.0725 & 0.00 & 30.1112 \\
\hline Triage.Queue & 0.3893 & 0.02 & 0.3555 & 0.4323 & 0.00 & 15.8813 \\
\hline XRay Process.Queue & 0.6428 & 0.05 & 0.5450 & 0.7634 & 0.00 & 26.5632 \\
\hline \multicolumn{7}{|l|}{ Other } \\
\hline Number Waiting & Average & Half Width & $\begin{array}{l}\text { Minimum } \\
\text { Average }\end{array}$ & $\begin{array}{c}\text { Maximum } \\
\text { Average }\end{array}$ & $\begin{array}{l}\text { Minimum } \\
\text { Value }\end{array}$ & $\begin{array}{r}\text { Maximum } \\
\text { Value }\end{array}$ \\
\hline Attending Visits.Queue & 0.1188 & 0.01 & 0.1027 & 0.1567 & 0.00 & 15.0000 \\
\hline CatScan Process.Queue & 0.00733453 & 0.00 & 0.00534235 & 0.00916052 & 0.00 & 3.0000 \\
\hline Last Visit.Queue & 0.00000552 & 0.00 & 0.00 & 0.00002286 & 0.00 & 2.0000 \\
\hline Nurse Visit Again.Queue & 0.00000316 & 0.00 & 0.00 & 0.00001300 & 0.00 & 1.0000 \\
\hline Nurse Visit.Queue & 0.00000017 & 0.00 & 0.00 & 0.00000161 & 0.00 & 1.0000 \\
\hline PCA Visits.Queue & 0.00025303 & 0.00 & 0.00013028 & 0.00037327 & 0.00 & 2.0000 \\
\hline Procedure Room Process.Queue & 0.00025501 & 0.00 & 0.00009384 & 0.00035669 & 0.00 & 2.0000 \\
\hline Resident Visits.Queve & 6.1913 & 0.20 & 5.7410 & 6.5405 & 0.00 & 28.0000 \\
\hline Seize Exam Room.Queve & 0.7601 & 0.12 & 0.6054 & 1.1531 & 0.00 & 33.0000 \\
\hline Technician Visits.Queue & 0.01442107 & 0.00 & 0.01282377 & 0.01629131 & 0.00 & 4.0000 \\
\hline Triage.Queue & 0.02869647 & 0.00 & 0.02644300 & 0.03203570 & 0.00 & 6.0000 \\
\hline XRay Process.Queue & 0.00701355 & 0.00 & 0.00574704 & 0.00841368 & 0.00 & 3.0000 \\
\hline
\end{tabular}




\section{Kosairs ER Simulation}

Replications: 10 Time Units: Minutes

\section{Resource}

\section{Usage}

\begin{tabular}{|c|c|c|c|c|c|c|}
\hline Instantaneous Utilization & Average & Half Width & $\begin{array}{c}\text { Minimum } \\
\text { Average }\end{array}$ & $\begin{array}{c}\text { Maximum } \\
\text { Average }\end{array}$ & $\begin{array}{c}\text { Minimum } \\
\text { Value }\end{array}$ & $\begin{array}{c}\text { Maximum } \\
\text { Value }\end{array}$ \\
\hline Additional Attending Physician & 0.7776 & 0.01 & 0.7591 & 0.7918 & 0.00 & 1.0000 \\
\hline Attending & 0.3219 & 0.00 & 0.3133 & 0.3288 & 0.00 & 1.0000 \\
\hline Catscan Machine & 0.1006 & 0.00 & 0.0962 & 0.1038 & 0.00 & 1.0000 \\
\hline Exam Room & 0.5191 & 0.01 & 0.5001 & 0.5327 & 0.00 & 1.0000 \\
\hline Nurse & 0.07487078 & 0.00 & 0.07418263 & 0.07634992 & 0.00 & 1.0000 \\
\hline Patient & 0.00 & 0.00 & 0.00 & 0.00 & 0.00 & 0.00 \\
\hline PCA & 0.05574445 & 0.00 & 0.05456896 & 0.05743551 & 0.00 & 1.0000 \\
\hline ProcedureRoom & 0.05267935 & 0.00 & 0.05090603 & 0.05442780 & 0.00 & 1.0000 \\
\hline Resident & 0.2384 & 0.00 & 0.2319 & 0.2443 & 0.00 & 0.5000 \\
\hline Technician & 0.1313 & 0.00 & 0.1254 & 0.1341 & 0.00 & 1.0000 \\
\hline Triage Nurse & 0.2332 & 0.00 & 0.2304 & 0.2355 & 0.00 & 1.0000 \\
\hline Triage Room & 0.2332 & 0.00 & 0.2304 & 0.2355 & 0.00 & 1.0000 \\
\hline Xray Machine & 0.1018 & 0.00 & 0.0972 & 0.1072 & 0.00 & 1.0000 \\
\hline Number Busy & Average & Half Width & $\begin{array}{c}\text { Minimum } \\
\text { Average }\end{array}$ & $\begin{array}{c}\text { Maximum } \\
\text { Average }\end{array}$ & $\begin{array}{c}\text { Minimum } \\
\text { Value }\end{array}$ & $\begin{array}{l}\text { Maximum } \\
\text { Value }\end{array}$ \\
\hline Additional Attending Physician & 0.7776 & 0.01 & 0.7591 & 0.7918 & 0.00 & 1.0000 \\
\hline Attending & 0.7096 & 0.01 & 0.6916 & 0.7285 & 0.00 & 3.0000 \\
\hline Catscan Machine & 0.1006 & 0.00 & 0.0962 & 0.1038 & 0.00 & 1.0000 \\
\hline Exam Room & 15.5742 & 0.22 & 15.0041 & 15.9801 & 0.00 & 30.0000 \\
\hline Nurse & 0.6322 & 0.00 & 0.6262 & 0.6435 & 0.00 & 9.0000 \\
\hline Patient & 0.00 & 0.00 & 0.00 & 0.00 & 0.00 & 0.00 \\
\hline PCA & 0.2147 & 0.00 & 0.2100 & 0.2221 & 0.00 & 5.0000 \\
\hline ProcedureRoom & 0.1054 & 0.00 & 0.1018 & 0.1089 & 0.00 & 2.0000 \\
\hline Resident & 0.7776 & 0.01 & 0.7591 & 0.7918 & 0.00 & 1.0000 \\
\hline Technician & 0.1313 & 0.00 & 0.1254 & 0.1341 & 0.00 & 1.0000 \\
\hline Triage Nurse & 0.4665 & 0.00 & 0.4609 & 0.4710 & 0.00 & 2.0000 \\
\hline Triage Room & 0.4665 & 0.00 & 0.4609 & 0.4710 & 0.00 & 2.0000 \\
\hline Xray Machine & 0.1018 & 0.00 & 0.0972 & 0.1072 & 0.00 & 1.0000 \\
\hline
\end{tabular}

Model Filename: F:IThesisiFinal modelsWew Staff SchedulelERSimulation Teach Only Attending 
Kosairs ER Simulation

Replications: $10 \quad$ Time Units: Minutes

Resource

Usage

\begin{tabular}{lrrrrrr} 
Number Scheduled & Average & Half Width & $\begin{array}{r}\text { Minimum } \\
\text { Average }\end{array}$ & $\begin{array}{r}\text { Maximum } \\
\text { Average }\end{array}$ & $\begin{array}{r}\text { Minimum } \\
\text { Value }\end{array}$ & $\begin{array}{r}\text { Maximum } \\
\text { Value }\end{array}$ \\
\hline Additional Attending Physician & 1.0000 & 0.00 & 1.0000 & 1.0000 & 1.0000 & 1.0000 \\
Attending & 2.2078 & 0.00 & 2.2074 & 2.2081 & 1.0000 & 3.0000 \\
Catscan Machine & 1.0000 & 0.00 & 1.0000 & 1.0000 & 1.0000 & 1.0000 \\
Exam Room & 30.0000 & 0.00 & 30.0000 & 30.0000 & 30.0000 & 30.0000 \\
Nurse & 8.5000 & 0.00 & 8.5000 & 8.5000 & 5.0000 & 12.0000 \\
Patient & 1.0000 & 0.00 & 1.0000 & 1.0000 & 1.0000 & 1.0000 \\
PCA & 3.8333 & 0.00 & 3.8333 & 3.8333 & 2.0000 & 5.0000 \\
ProcedureRoom & 2.0000 & 0.00 & 2.0000 & 2.0000 & 2.0000 & 2.0000 \\
Resident & 3.2917 & 0.00 & 3.2917 & 3.2917 & 2.0000 & 4.0000 \\
Technician & 1.0000 & 0.00 & 1.0000 & 1.0000 & 1.0000 & 1.0000 \\
Triage Nurse & 2.0000 & 0.00 & 2.0000 & 2.0000 & 2.0000 & 2.0000 \\
Triage Room & 2.0000 & 0.00 & 2.0000 & 2.0000 & 2.0000 & 2.0000 \\
Xray Machine & 1.0000 & 0.00 & 1.0000 & 1.0000 & 1.0000 & 1.0000
\end{tabular}




\section{Kosairs ER Simulation}

Replications: 10 Time Units: Minutes

\section{Resource}

Usage

\begin{tabular}{lrrrr} 
Scheduled Utilization & Average & Half Width & $\begin{array}{r}\text { Minimum } \\
\text { Average }\end{array}$ & $\begin{array}{r}\text { Maximum } \\
\text { Average }\end{array}$ \\
\hline Additional Attending Physician & 0.7776 & 0.01 & 0.7591 & 0.7918 \\
Attending & 0.3214 & 0.00 & 0.3132 & 0.3299 \\
Catscan Machine & 0.1006 & 0.00 & 0.0962 & 0.1038 \\
Exam Room & 0.5191 & 0.01 & 0.5001 & 0.5327 \\
Nurse & 0.07438097 & 0.00 & 0.07367590 & 0.07570075 \\
Patient & 0.00 & 0.00 & 0.00 & 0.00 \\
PCA & 0.05601642 & 0.00 & 0.05478411 & 0.05794634 \\
ProcedureRoom & 0.05267935 & 0.00 & 0.05090603 & 0.05442780 \\
Resident & 0.2362 & 0.00 & 0.2306 & 0.2406 \\
Technician & 0.1313 & 0.00 & 0.1254 & 0.1341 \\
Triage Nurse & 0.2332 & 0.00 & 0.2304 & 0.2355 \\
Triage Room & 0.2332 & 0.00 & 0.2304 & 0.2355 \\
Xray Machine & 0.1018 & 0.00 & 0.0972 & 0.1072
\end{tabular}

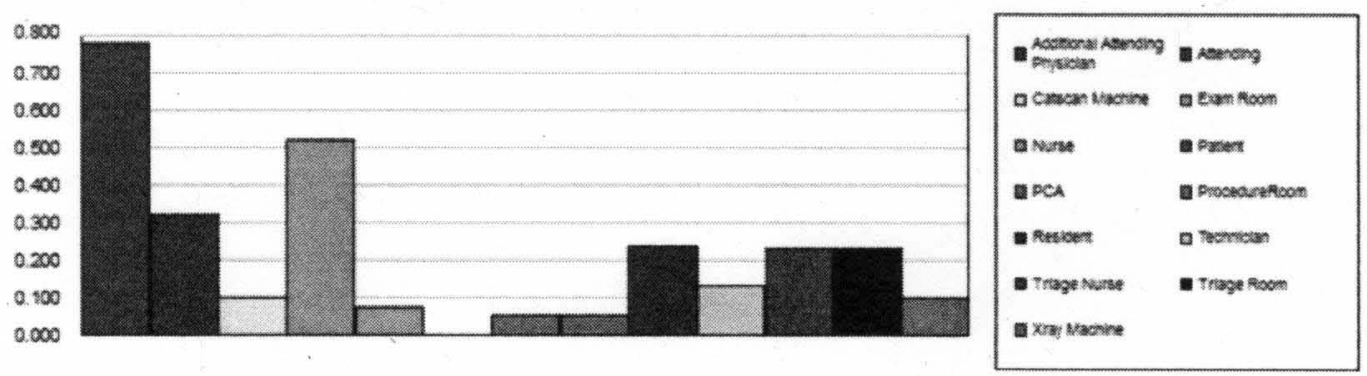




\section{Kosairs ER Simulation}

Replications: $10 \quad$ Time Units: Minutes

\section{Resource}

\section{Usage}

\begin{tabular}{|c|c|c|c|c|c|c|}
\hline Total Number Seized & Average & Half Width & $\begin{array}{c}\text { Minimum } \\
\text { Average }\end{array}$ & $\begin{array}{r}\text { Maximum } \\
\text { Average }\end{array}$ & & \\
\hline Additional Attending Physician & 11983.00 & 91.36 & 11679.00 & 12116.00 & & \\
\hline Attending & 10939.30 & 101.13 & 10691.00 & 11153.00 & & \\
\hline Catscan Machine & 1350.60 & 19.71 & 1301.00 & 1391.00 & & \\
\hline Exam Room & 9231.50 & 38.48 & 9155.00 & 9320.00 & & \\
\hline Nurse & 31224.00 & 170.46 & 30899.00 & 31633.00 & & \\
\hline Patient & 0.00 & 0.00 & 0.00 & 0.00 & & \\
\hline PCA & 6766.50 & 64.62 & 6616.00 & 6931.00 & & \\
\hline ProcedureRoom & 1415.10 & 24.29 & 1365.00 & 1464.00 & & \\
\hline Resident & 11983.00 & 91.36 & 11679.00 & 12116.00 & & \\
\hline Technician & 1897.30 & 33.72 & 1811.00 & 1951.00 & & \\
\hline Triage Nurse & 9236.00 & 37.64 & 9164.00 & 9318.00 & & \\
\hline Triage Room & 9236.00 & 37.64 & 9164.00 & 9318.00 & & \\
\hline Xray Machine & 1364.30 & 28.18 & 1300.00 & 1440.00 & & \\
\hline 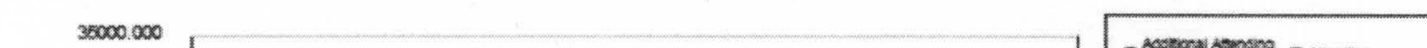 & & & & & 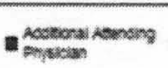 & In anows \\
\hline 25000,000 & & & & & a comen warien & a cam form \\
\hline 20000000 & & & & & a wase & apres \\
\hline 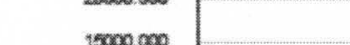 & & & & & apea & a propencertion \\
\hline 100000000 & & & & & newoen & a somean \\
\hline 5000.000 & & & & & - Troge Nusese & Irouge room \\
\hline 0.000 & & & & & axom vantse & \\
\hline
\end{tabular}


Kosairs ER Simulation

Replications: 10 Time Units: Minutes

User Specified

\section{Counter}

\begin{tabular}{lrrrr} 
Count & Average & Half Width & $\begin{array}{r}\text { Minimum } \\
\text { Average }\end{array}$ & $\begin{array}{r}\text { Maximum } \\
\text { Average }\end{array}$ \\
\hline CatScan Count & 1350.60 & 19.71 & 1301.00 & 1391.00 \\
Leaves ER Count & 9227.50 & 40.89 & 9146.00 & 9320.00 \\
Procedure Room Count & 1415.10 & 24.29 & 1365.00 & 1464.00 \\
Stays in Room Count & 40221.00 & 227.42 & 39719.00 & 40656.00 \\
XRay Count & 1364.30 & 28.00 & 1301.00 & 1440.00
\end{tabular}

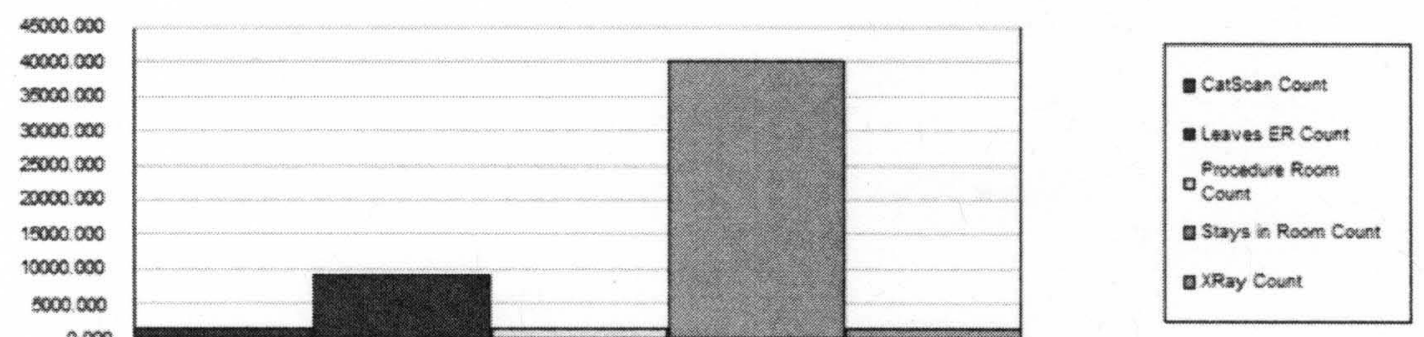


APPENDIX VII

ARENA RESULTS OF ATTENDING WITH RESIDENT METHOD WITH STAFF

CHANGES 
Kosairs ER Simulation

Replications: 10 Time Units: Minutes

Key Performance Indicators

System

Average

Number Out

9,261 
Values Across All Replications

Kosairs ER Simulation

Replications: 10 Time Unils: Minutes

\section{Entity}

\section{Time}

\begin{tabular}{|c|c|c|c|c|c|c|}
\hline VA Time & Average & Half Width & $\begin{array}{c}\text { Minimum } \\
\text { Average }\end{array}$ & $\begin{array}{l}\text { Maximum } \\
\text { Average }\end{array}$ & $\begin{array}{c}\text { Minimum } \\
\text { Value }\end{array}$ & $\begin{array}{l}\text { Maximum } \\
\text { Value }\end{array}$ \\
\hline Patient 1 & 46.3370 & 0.17 & 45.9985 & 46.7845 & 6.4396 & 308.96 \\
\hline NVA Time & Average & Half Width & $\begin{array}{l}\text { Minimum } \\
\text { Average }\end{array}$ & $\begin{array}{c}\text { Maximum } \\
\text { Average }\end{array}$ & $\begin{array}{l}\text { Minimum } \\
\text { Value }\end{array}$ & $\begin{array}{l}\text { Maximum } \\
\text { Value }\end{array}$ \\
\hline Patient 1 & 0.00 & 0.00 & 0.00 & 0.00 & 0.00 & $\overline{0.00}$ \\
\hline Wait Time & Average & Half Width & $\begin{array}{c}\text { Minimum } \\
\text { Average }\end{array}$ & $\begin{array}{r}\text { Maximum } \\
\text { Average }\end{array}$ & $\begin{array}{c}\text { Minimum } \\
\text { Value }\end{array}$ & $\begin{array}{r}\text { Maximum } \\
\text { Value }\end{array}$ \\
\hline Patient 1 & 155.03 & 2.58 & 149.65 & 159.91 & 12.4166 & 1772.94 \\
\hline Transfer Time & Average & Half Width & $\begin{array}{c}\text { Minimum } \\
\text { Average }\end{array}$ & $\begin{array}{r}\text { Maximum } \\
\text { Average }\end{array}$ & $\begin{array}{c}\text { Minimum } \\
\text { Value }\end{array}$ & $\begin{array}{l}\text { Maximum } \\
\text { Value }\end{array}$ \\
\hline Patient 1 & 2.6692 & 0.01 & 2.6467 & 2.6790 & 2.0000 & 8.0000 \\
\hline Other Time & Average & Haff Width & $\begin{array}{c}\text { Minimum } \\
\text { Average }\end{array}$ & $\begin{array}{c}\text { Maximum } \\
\text { Average }\end{array}$ & $\begin{array}{c}\text { Minimum } \\
\text { Value }\end{array}$ & $\begin{array}{l}\text { Maximum } \\
\text { Value }\end{array}$ \\
\hline Patient 1 & 0.00 & 0.00 & 0.00 & 0.00 & 0.00 & $\overline{0.00}$ \\
\hline Total Time & Average & Half Width & $\begin{array}{c}\text { Minimum } \\
\text { Average }\end{array}$ & $\begin{array}{c}\text { Maximum } \\
\text { Average }\end{array}$ & $\begin{array}{c}\text { Minimum } \\
\text { Value }\end{array}$ & $\begin{array}{l}\text { Maximum } \\
\text { Value }\end{array}$ \\
\hline $\begin{array}{l}\text { Patient } 1 \\
\text { Other }\end{array}$ & 204.03 & 2.68 & 198.48 & 209.12 & 30.5352 & 1826.57 \\
\hline Number in & Average & Half Width & $\begin{array}{l}\text { Minimum } \\
\text { Average }\end{array}$ & $\begin{array}{r}\text { Maximum } \\
\text { Average }\end{array}$ & & \\
\hline Patient 1 & 9262.20 & 58.64 & 9138.00 & 9384.00 & & \\
\hline Number Out & Average & Half Width & $\begin{array}{l}\text { Minimum } \\
\text { Average }\end{array}$ & $\begin{array}{c}\text { Maximum } \\
\text { Average }\end{array}$ & & \\
\hline Patient 1 & 9261.20 & 58.12 & 9128.00 & 9385.00 & & \\
\hline WIP & Average & Half Width & $\begin{array}{c}\text { Minimum } \\
\text { Average }\end{array}$ & $\begin{array}{r}\text { Maximum } \\
\text { Average }\end{array}$ & $\begin{array}{c}\text { Minimum } \\
\text { Value }\end{array}$ & $\begin{array}{l}\text { Maximum } \\
\text { Value }\end{array}$ \\
\hline Patient 1 & 15.0844 & 0.27 & 14.5475 & 15.6349 & 0.00 & 56.0000 \\
\hline
\end{tabular}




\section{Kosairs ER Simulation}

Replications: $10 \quad$ Time Units: Minutes

\section{Queue}

\section{Time}

\begin{tabular}{|c|c|c|c|c|c|c|}
\hline Waiting Time & Average & Half Width & $\begin{array}{l}\text { Minimum } \\
\text { Average }\end{array}$ & $\begin{array}{c}\text { Maximum } \\
\text { Average }\end{array}$ & $\begin{array}{c}\text { Minimum } \\
\text { Value }\end{array}$ & $\begin{array}{c}\text { Maximum } \\
\text { Value }\end{array}$ \\
\hline Attending Visits.Queue & 11.5912 & 0.74 & 10.2105 & 13.1129 & 0.00 & 254.53 \\
\hline CatScan Process.Queue & 0.6990 & 0.08 & 0.5467 & 0.8348 & 0.00 & 30.5339 \\
\hline Last Visit.Queue & 0.00003141 & 0.00 & 0.00 & 0.00031409 & 0.00 & 1.5126 \\
\hline Nurse Visit Again.Queue & 0.00 & 0.00 & 0.00 & 0.00 & 0.00 & 0.00 \\
\hline Nurse Visit.Queue & 0.00 & 0.00 & 0.00 & 0.00 & 0.00 & 0.00 \\
\hline PCA Visits.Queue & 0.00225344 & 0.00 & 0.00048661 & 0.00521946 & 0.00 & 4.9002 \\
\hline Procedure Room Process.Queue & 0.03068447 & 0.01 & 0.01724990 & 0.04935227 & 0.00 & 10.5108 \\
\hline Seize Exam Room.Queue & 1.4945 & 0.53 & 0.7218 & 3.3226 & 0.00 & 304.73 \\
\hline Technician Visits.Queue & 1.1505 & 0.08 & 1.0176 & 1.3477 & 0.00 & 34.0178 \\
\hline Triage.Queue & 0.4031 & 0.02 & 0.3628 & 0.4345 & 0.00 & 25.9730 \\
\hline XRay Process.Queue & 0.7105 & 0.05 & 0.5955 & 0.8941 & 0.00 & 24.5577 \\
\hline \multicolumn{7}{|l|}{ Other } \\
\hline Number Waiting & Average & Half Width & $\begin{array}{l}\text { Minimum } \\
\text { Average }\end{array}$ & $\begin{array}{c}\text { Maximum } \\
\text { Average }\end{array}$ & $\begin{array}{l}\text { Minimum } \\
\text { Value }\end{array}$ & $\begin{array}{l}\text { Maximum } \\
\text { Value }\end{array}$ \\
\hline Attending Visits.Queue & 2.1524 & 0.15 & 1.8674 & 2.4622 & 0.00 & 28.0000 \\
\hline CatScan Process.Queue & 0.00761260 & 0.00 & 0.00566804 & 0.00915658 & 0.00 & 4.0000 \\
\hline Last Visit.Queue & 0.00000232 & 0.00 & 0.00 & 0.00002325 & 0.00 & 1.0000 \\
\hline Nurse Visit Again.Queue & 0.00 & 0.00 & 0.00 & 0.00 & 0.00 & 0.00 \\
\hline Nurse Visit.Queue & 0.00 & 0.00 & 0.00 & 0.00 & 0.00 & 0.00 \\
\hline PCA Visits.Queue & 0.00012389 & 0.00 & 0.00002726 & 0.00028593 & 0.00 & 2.0000 \\
\hline Procedure Room Process.Queue & 0.00034797 & 0.00 & 0.00018891 & 0.00057830 & 0.00 & 2.0000 \\
\hline Seize Exam Room.Queue & 0.1108 & 0.04 & 0.05275888 & 0.2489 & 0.00 & 21.0000 \\
\hline Technician Visits.Queue & 0.01794808 & 0.00 & 0.01575524 & 0.02154667 & 0.00 & 5.0000 \\
\hline Triage.Queue & 0.02981751 & 0.00 & 0.02650861 & 0.03248610 & 0.00 & 8.0000 \\
\hline XRay Process.Queue & 0.00784559 & 0.00 & 0.00641702 & 0.01012683 & 0.00 & 3.0000 \\
\hline
\end{tabular}


Kosairs ER Simulation

Replications: 10 Time Units: Minutes

\section{Resource}

\section{Usage}

\begin{tabular}{|c|c|c|c|c|c|c|}
\hline Instantaneous Utilization & Average & Half Width & $\begin{array}{c}\text { Minimum } \\
\text { Average }\end{array}$ & $\begin{array}{r}\text { Maximum } \\
\text { Average }\end{array}$ & $\begin{array}{c}\text { Minimum } \\
\text { Value }\end{array}$ & $\begin{array}{l}\text { Maximum } \\
\text { Value }\end{array}$ \\
\hline Attending & 0.6542 & 0.01 & 0.6396 & 0.6648 & 0.00 & 1.0000 \\
\hline Catscan Machine & 0.1013 & 0.00 & 0.0961 & 0.1054 & 0.00 & 1.0000 \\
\hline Exam Room & 0.3844 & 0.01 & 0.3687 & 0.3973 & 0.00 & 1.0000 \\
\hline Nurse & 0.07175336 & 0.00 & 0.07057247 & 0.07304316 & 0.00 & 1.0000 \\
\hline Patient & 0.00 & 0.00 & 0.00 & 0.00 & 0.00 & 0.00 \\
\hline PCA & 0.05505216 & 0.00 & 0.05388464 & 0.05606498 & 0.00 & 1.0000 \\
\hline ProcedureRoom & 0.05281930 & 0.00 & 0.05114711 & 0.05481613 & 0.00 & 1.0000 \\
\hline Resident & 0.4338 & 0.00 & 0.4256 & 0.4407 & 0.00 & 1.0000 \\
\hline Technician & 0.1349 & 0.00 & 0.1308 & 0.1414 & 0.00 & 1.0000 \\
\hline Triage Nurse & 0.2338 & 0.00 & 0.2306 & 0.2371 & 0.00 & 1.0000 \\
\hline Triage Room & 0.2338 & 0.00 & 0.2306 & 0.2371 & 0.00 & 1.0000 \\
\hline Xray Machine & 0.1030 & 0.00 & 0.0989 & 0.1062 & 0.00 & 1.0000 \\
\hline Number Busy & Average & Half Width & $\begin{array}{l}\text { Minimum } \\
\text { Average }\end{array}$ & $\begin{array}{c}\text { Maximum } \\
\text { Average }\end{array}$ & $\begin{array}{c}\text { Minimum } \\
\text { Value }\end{array}$ & $\begin{array}{c}\text { Maximum } \\
\text { Value }\end{array}$ \\
\hline Attending & 1.5070 & 0.02 & 1.4693 & 1.5420 & 0.00 & 3.0000 \\
\hline Catscan Machine & 0.1013 & 0.00 & 0.0961 & 0.1054 & 0.00 & 1.0000 \\
\hline Exam Room & 11.5325 & 0.22 & 11.0606 & 11.9189 & 0.00 & 30.0000 \\
\hline Nurse & 0.6384 & 0.00 & 0.6268 & 0.6461 & 0.00 & 9.0000 \\
\hline Patient & 0.00 & 0.00 & 0.00 & 0.00 & 0.00 & 0.00 \\
\hline PCA & 0.2200 & 0.00 & 0.2156 & 0.2236 & 0.00 & 5.0000 \\
\hline ProcedureRoom & 0.1056 & 0.00 & 0.1023 & 0.1096 & 0.00 & 2.0000 \\
\hline Resident & 1.5070 & 0.02 & 1.4693 & 1.5420 & 0.00 & 3.0000 \\
\hline Technician & 0.1349 & 0.00 & 0.1308 & 0.1414 & 0.00 & 1.0000 \\
\hline Triage Nurse & 0.4676 & 0.00 & 0.4612 & 0.4742 & 0.00 & 2.0000 \\
\hline Triage Room & 0.4676 & 0.00 & 0.4612 & 0.4742 & 0.00 & 2.0000 \\
\hline Xray Machine & 0.1030 & 0.00 & 0.0989 & 0.1062 & 0.00 & 1.0000 \\
\hline
\end{tabular}




\section{Kosairs ER Simulation}

Replications: 10 Time Units: Minutes

\section{Resource}

Usage

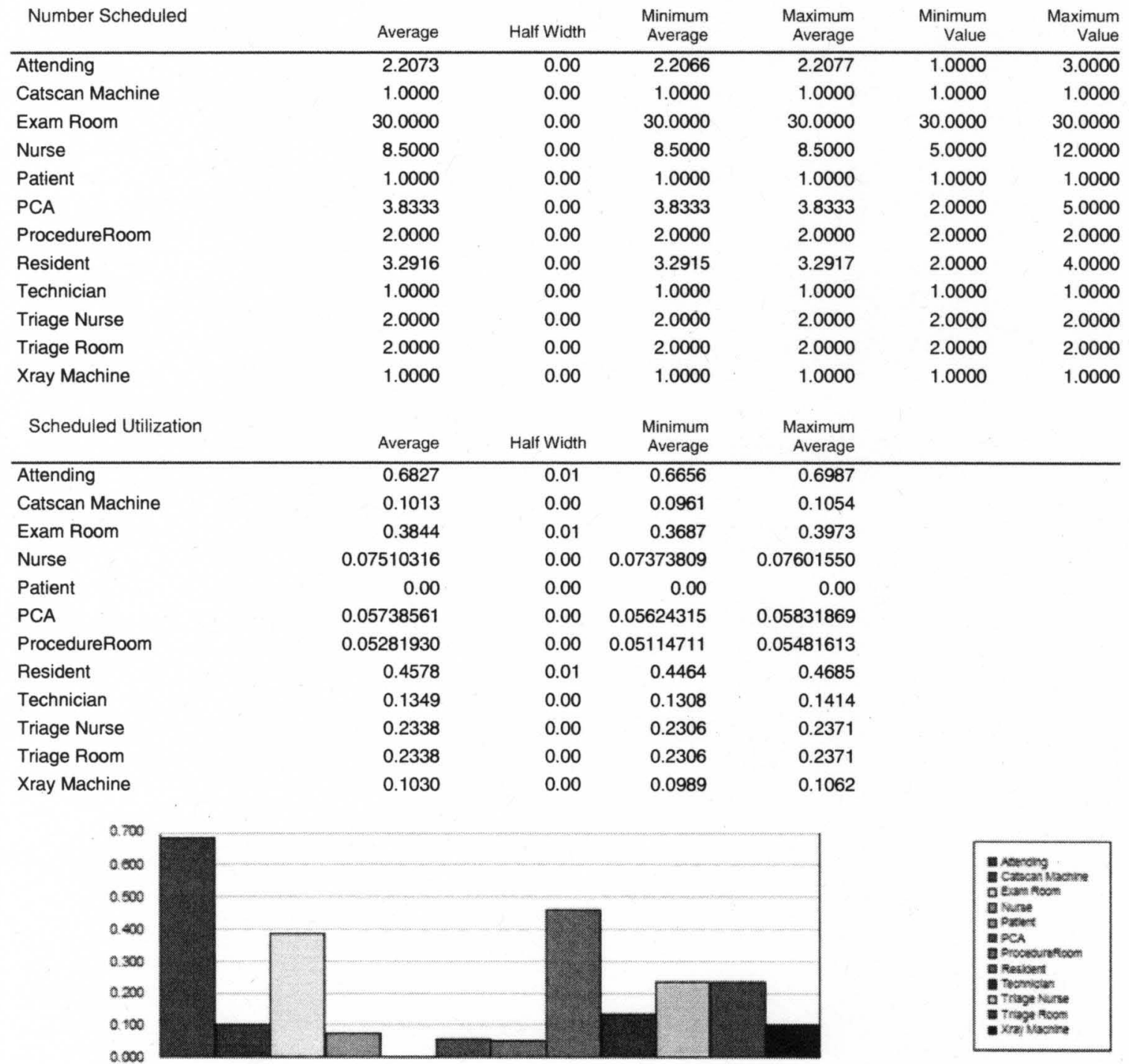




\section{Kosairs ER Simulation}

Replications: 10 Time Units: Minutes

\section{Resource}

\section{Usage}

\begin{tabular}{|c|c|c|c|c|c|}
\hline Total Number Seized & Average & Half Width & $\begin{array}{c}\text { Minimum } \\
\text { Average }\end{array}$ & $\begin{array}{c}\text { Maximum } \\
\text { Average }\end{array}$ & \\
\hline Attending & 23242.60 & 215.86 & 22757.00 & 23634.00 & \\
\hline Catscan Machine & 1362.10 & 27.62 & 1297.00 & 1417.00 & \\
\hline Exam Room & 9262.10 & 57.91 & 9140.00 & 9383.00 & \\
\hline Nurse & 31500.20 & 201.04 & 31055.00 & 31872.00 & \\
\hline Patient & 0.00 & 0.00 & 0.00 & 0.00 & \\
\hline PCA & 6888.70 & 80.69 & 6739.00 & 7020.00 & \\
\hline ProcedureRoom & 1416.40 & 26.54 & 1363.00 & 1472.00 & \\
\hline Resident & 23242.60 & 215.86 & 22757.00 & 23634.00 & \\
\hline Technician & 1950.60 & 39.89 & 1881.00 & 2042.00 & \\
\hline Triage Nurse & 9262.30 & 58.09 & 9138.00 & 9382.00 & \\
\hline Triage Room & 9262.30 & 58.09 & 9138.00 & 9382.00 & \\
\hline Xray Machine & 1382.30 & 20.60 & 1333.00 & 1421.00 & \\
\hline 30000.000 & & & & & \\
\hline 300000.000 & & & & & a Aenomg \\
\hline 20000.000 & & & & & 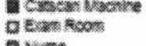 \\
\hline 200000000 & & & & & Eprent \\
\hline 150000000 & & & & & EProseouretesom \\
\hline 100000.000 & & & & & 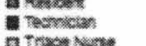 \\
\hline 5000.000 & & & & & 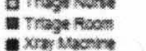 \\
\hline
\end{tabular}


Kosairs ER Simulation

Replications: $10 \quad$ Time Units: Minutes

\section{User Specified}

\section{Counter}

\begin{tabular}{|c|c|c|c|c|c|}
\hline Count & Average & Half Width & $\begin{array}{c}\text { Minimum } \\
\text { Average }\end{array}$ & $\begin{array}{r}\text { Maximum } \\
\text { Average }\end{array}$ & \\
\hline CatScan Count & 1362.10 & 27.62 & 1297.00 & 1417.00 & \\
\hline Leaves ER Count & 9261.20 & 58.12 & 9128.00 & 9385.00 & \\
\hline Procedure Room Count & 1416.30 & 26.42 & 1363.00 & 1471.00 & \\
\hline Stays in Room Count & 40899.60 & 360.55 & 40093.00 & 41522.00 & \\
\hline XRay Count & 1382.20 & 20.69 & 1333.00 & 1421.00 & \\
\hline \multicolumn{6}{|l|}{45000.000} \\
\hline \multicolumn{6}{|l|}{$\$ 0000.000$} \\
\hline \multicolumn{6}{|l|}{30000000} \\
\hline \multicolumn{6}{|r|}{ - Leaves ER Coumt } \\
\hline \multicolumn{6}{|r|}{ Procedure Room } \\
\hline \multicolumn{6}{|l|}{20000.000} \\
\hline \multicolumn{6}{|r|}{ a Stays in Room Count } \\
\hline \multicolumn{6}{|l|}{10000,000} \\
\hline 5000,000 & & & & & \\
\hline
\end{tabular}




\title{
CURRICULUM VITAE
}

\author{
SCOTT HOOVER \\ 8800 Park Laureate Dr. \\ Louisville, KY 40220 \\ Srhoov01@louisville.edu
}

\section{EDUCATION}

Aug 2010-present

University of Louisville, J.B. Speed School of Engineering

Louisville, KY

Doctorate in Engineering/Industrial Engineering

Graduation: May 2013

Aug 2009-Dec 2010

University of Louisville, J.B. Speed School of Engineering

Louisville, KY

Masters of Science/Industrial Engineering

Graduation: December 2010

Aug 2005-May 2009

University of Louisville

Louisville, KY

Bachelor of Arts in Mathematics

Graduation: May 2009

\section{ACTIVITIES \& AWARDS}

Institute of Industrial Engineers

Human Factors and Ergonomics Society

Industrial Engineering Teaching Assistant

President Scholarship (2005-2009) 